University of Louisville

ThinkIR: The University of Louisville's Institutional Repository

Electronic Theses and Dissertations

$5-2014$

\title{
The rise of Bulgarian nationalism and Russia's influence upon it.
}

Lin Wenshuang

University of Louisville

Follow this and additional works at: https://ir.library.louisville.edu/etd

Part of the Arts and Humanities Commons

\section{Recommended Citation}

Wenshuang, Lin, "The rise of Bulgarian nationalism and Russia's influence upon it." (2014). Electronic Theses and Dissertations. Paper 1548.

https://doi.org/10.18297/etd/1548

This Doctoral Dissertation is brought to you for free and open access by ThinkIR: The University of Louisville's Institutional Repository. It has been accepted for inclusion in Electronic Theses and Dissertations by an authorized administrator of ThinkIR: The University of Louisville's Institutional Repository. This title appears here courtesy of the author, who has retained all other copyrights. For more information, please contact thinkir@louisville.edu. 
THE RISE OF BULGARIAN NATIONALISM AND

RUSSIA‘S INFLUENCE UPON IT

by

Lin Wenshuang

B. A., Beijing Foreign Studies University, China, 1997

M. A., Beijing Foreign Studies University, China, 2002

\author{
A Dissertation \\ Submitted to the Faculty of the \\ College of Arts and Sciences of the University of Louisville \\ in Partial Fulfillment of the Requirements \\ for the Degree of \\ Doctor of Philosophy \\ Department of Humanities \\ University of Louisville \\ Louisville, Kentucky
}

May 2014 
Copyright (C) 2014 by Lin Wenshuang

All Rights Reserved 

THE RISE OF BULGARIAN NATIONALISM AND

RUSSIA‘S INFLUENCE UPON IT

by

Lin Wenshuang

B. A., Beijing Foreign Studies University, China, 1997

M. A., Beijing Foreign Studies University, China, 2002

A Dissertation Approved on

April 1, 2014

By the following Dissertation Committee

Prof. Dr. Mark Blum (Director)

Prof. Dr. Charles Ziegler

Prof. Dr. Shiping Hua

Prof. Dr. Svetlana Stoicheva 


\section{ACKNOWLEDGEMENTS}

The completion of a dissertation is a long journey. From the beginning of my academic journey, many have contributed to my learning and writing experience.

First and foremost, I would like to express the deepest gratitude to my dissertation director, Prof. Mark Blum who has the attitude and the substance of a genius: he always conveyed convincingly a spirit of adventure and creativity in regard to research and scholarship, and an excitement in regard to teaching. Without his guidance and persistent help, I would not been able to complete this dissertation.

I would like to thank my committee members, Professor Charles Ziegler, Prof. Hua Shiping and Prof. Svetlana Stoicheva Anderson, whose work demonstrated to me that concern for global affairs should always transcend academia and provide a quest for our times. Their valuable comments and warm support encouraged me to complete this long journey.

I am lucky to be part of the joint joint Ph. D. Program between the University of Louisville (UofL) and Beijing Foreign Studies University (BFSU). I appreciate the lectures offered by the professors, which led me to an academic world with humanistic spirit. They are Prof. Annette Allen, Prof. Osborne Wiggins, Prof. Elaine Wise, Prof. Robert St. Clair, Dr. Pamela Beattie from UofL and Prof. Jin Li, Prof. Sun Youzhong, Prof. Zhang Jian, Prof. Wu Yi'an, Prof. Zhang Zaixin and Prof. Chen Guohua from BFSU.

My special thanks also go to Dr. Sun Xiujie, the coordinator of the Program, for 
her full support and indispensable help. In addition, I would like to give a thank you" to Carly Johnson, Rick and Adam of the Virtual Writing Center of UofL, and also to my friend Li Menghong and Ke Liejuan for giving advice on proper writing and their thoughtful and careful editing.

I owe also my sincere gratitude to my colleagues: Prof. Ding Chao, Prof. Ge Zhiqiang, Prof. Zhao Gang, Prof. Ke Jing, Prof. Chen Ying, and to our Bulgarian lectors Lyuba Atanasova and Mariana Tian. Their support and warm help have contributed to the completion of my dissertation.

Finally, I would like to thank my family: my parents, my husband and my baby daughter. Without their continuing love and unconditional support, this dissertation would not have been possible.

Thank you all. 


\section{ABSTRACT \\ THE RISE OF BULGARIAN NATIONALISM AND \\ RUSSIA'S INFLUENCE UPON IT}

by

\section{Lin Wenshuang}

April 1, 2014

The exercise of nationalism is the assertion of the political sovereignty of a community in the form of a nation-state. In the case of Bulgaria, nationalism, in practice, was a long journey towards the establishment of a Bulgarian nation-state. This dissertation aims to clarify the place and role of nationalism in the reconstruction of the Bulgarian state and to examine to what extent the development of Bulgarian nationalism was influenced by Russia at the vital stage - the 1870s, when the nation fought hard against Ottoman rule and finally achieved national liberation.

My motivation for examining Russo-Bulgarian historical, political and cultural relations and Russian elements in the rise of Bulgarian nationalism is to offer an example for future studies in how to construct a rational pattern of relationship between great powers and small nations with common faith and culture.

The investigation in this dissertation is conducted in five disciplines: political science (constructivism), historiography, journalism, linguistics and literature. I apply a constructivist approach in discussing the factual process and structural change" over a period of time in the Bulgarian public world, as well as how Russo-Bulgarian 
relations influenced the development of Bulgarian nationalism. Constructivism states that the structure leads actors to redefine their identities and interests in the process of interacting and that structures can be changed through acts of social and public will. By investigating a great number of primary documents, as well as analyzing the linguistic evolution of the Bulgarian, this dissertation concludes that Bulgarian national identity is not fixed or resistant to change, but fluid. It changes according to how the people (particularly the national elites) evaluate the domestic and international circumstances at a certain time and place.

By examining the rise of Bulgarian nationalism, this research highlights Russia's special and complicated identity represented in the fluidity of Bulgarian national identity, concluding that Russia, as a Great Power, to which the Bulgarian national elites often went, played dual roles in the formation of the Bulgarian national identity and the consolidation of the Bulgarian nationalism.

Based on the observation that Bulgarian nationalism played different roles in different historical periods, my project proves that nationalism is a process that defines, creates, and expresses the essential loyalty to the nation, and the term nationalism ought to be viewed in a neutral sense. 


\section{TABLE OF CONTENTS}

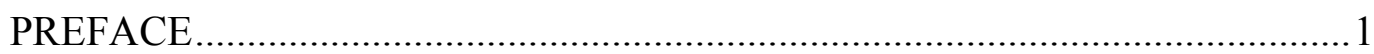

What is nationalism and why constructivism? ...........................................

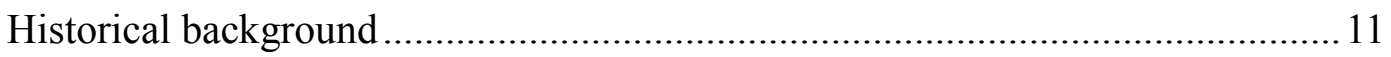

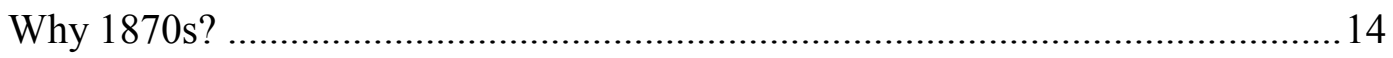

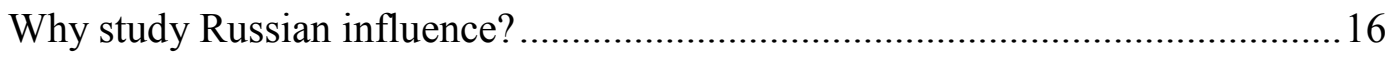

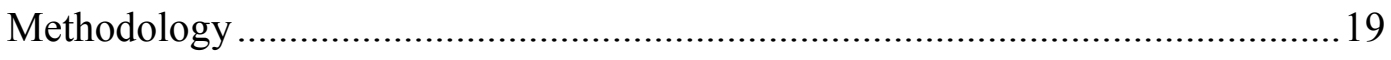

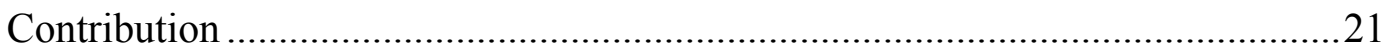

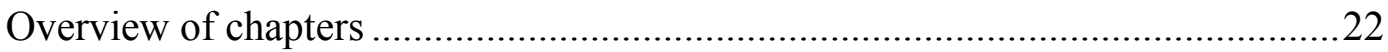

CHAPTER 1 THE PROCESS AND STRUCTURAL CHANGE THROUGH

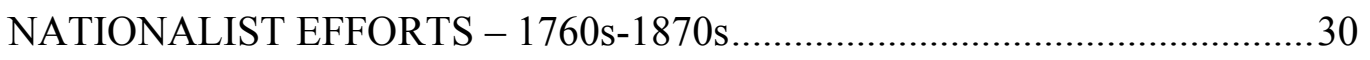

1.1 Bourgeois economic relations and new political ideas in the resistance against the

Ottoman rule 33

1.2 Participation in the liberation movements of Balkan friends" and expectation of rescue from - gi Brother". 39

1.3 From reliance on external forces to action of internal self-liberating. .46

1.4 Liberation of Bulgaria - furitless effort to control own destiny 53

1.5 Discussion 58 


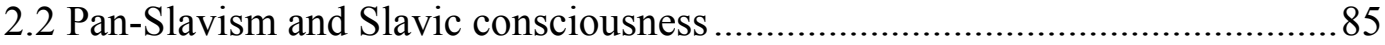

2.3 Cultural identification versus political alienation .......................................90

CHAPTER 3 PUBLIC POLICY AND ITS REFLECTION IN BULGARIAN

MEDIA .97

3.1 Urgent requirement for the independence of the Church. 99

3.2 Pre-state of April Uprising 105

3.3 National Liberation: relying on the Great Powers or self-strengthening? .....107

3.4 Ambiguous attitude toward Russia - hopeful and incredulous

3.5 After the Russo-Turkish War.

CHAPTER 4 LANGUAGE AS A STIMULUS FOR BULGARIAN NATIONALISM 124

4.1 To eliminate the effects of the Greek language. 127

4.2 Dialects versus Church Slavonic 132

4.3 From language purity to purism 138

4.4 The place of Russian in the construction of the Modern Bulgarian language 145

CHAPTER 5 IVAN VAZOV'S UNDER THE YOKE - NARRATING THE TIME 159

5.1 The author and the work 159

5.2 Air of Bulgaria 164 
5.4 The two Others in the work

CHAPTER 6 SUMMARY AND CONCLUSION

6.1 The fluidity of Bulgarian national identity 191

6.2 The identity of Russia in Bulgarian nationalism. 199

6.3 Is nationalism good or bad for Bulgaria? 205

REFERENCES 


\section{PREFACE}

It is melancholy, but it is also true, that $\mathrm{we}^{1}$, who upon this Eastern ground fought with Russia,... have actually for months past been indebted, and are even now indebted, to all or some of these very Powers, possibly to Russia most among them, for having played the part which we think specially our own, in resistance to tyranny, in befriending the oppressed, in labouring for the happiness of mankind. I say the time has come for us to emulate Russia by, sharing in her good deeds, and to reserve our opposition until she shall visibly endeavour to turn them to evil account.

-- William E. Gladstone, Britain Liberal politician, The Bulgarian Horrors and the Question of the East $(1876)^{2}$

I am profoundly convinced that Russia has never had and will not have such haters, enviers, calumniators and overt enemies like all Slavic tribes will be after being liberated with the aid of Russia... Perhaps in one century, if not more, they will be fearful for their freedom and Russia's love of power, and will curry favor with European countries, vilifying Russia.

-- Fyodor M. Dostoyevsky, $1877^{3}$

In 1876, the year when the April Uprising was brutally suppressed by the Ottoman Turks and the year before the Russo-Turkish War (1877-1878) broke out, the British opposition leader at the time, William Gladstone published his Bulgarian Horror and the Question of the East, calling upon Britain to withdraw its support for the Ottoman Turkey and praising Russia, Britain's rival in the issue of the Eastern Question, for its endeavor to befriend the oppressed" and the happiness of mankind". His contemporary, Fyodor Dostoyevsky, one of the most distinguished 
Russian novelists and an unconscious Slavophile ${ }^{4}$, expressed his surprisingly pessimistic prediction about the future attitude held by all Slavic nations towards Russia in the following year, when Russian troops was attacking the Turks associated with is Balkan Orthodox allies. Dostoyevsky himself advocated the establishment of a Slavic union by the liberation of all Slavs and the conquest of Constantinople ${ }^{5}$.

The tremendous contrast between the responses of the two figures makes us curious about what happened to the Balkan Slavs during the national liberation movements, and what had Russia done to the Balkans at the time. Taking Bulgaria as a case for research, this dissertation aims to clarify the place and role of nationalism in the reconstruction of the Bulgarian state, and to examine to what extent the development of Bulgarian nationalism was influenced by Russia at the vital stage the 1870 s, when the nation fought hard against Ottoman rule and finally achieved national liberation.

The investigation on this thesis will be drawing on insights from five disciplines: political science (constructivism), historiography, journalism, linguistics and literature. Why I use these five disciplines as my forms of evidence to build the case? How can one discipline complement another by presenting different kinds of evidence to distinguish itself from other methods? The answers are as the follows:

(1) Constructivism offers a theoretical basis for historiography investigation, revealing the relationships underlying historical events and conditions. Moreover, it can establish an organic link with another discipline - journalism. 
(2) Historiography gives us a coherent thread of the evolution of Bulgarian nationalism. Without its support, any study in other disciplines would be isolated. In other words, the investigation into journalism, literature and linguistics cannot be conducted without considering the historical background.

(3) Journalism can demonstrate public will — approval or disapproval, acceptance or rejection, praise or blame to some policies and historical events, which an academic history cannot do.

(4) Linguistics is a more convincing instrument for studying a nation than journalism and literature because it is often used to support nationalistic ideologies in a insignificant yet enduring way.

(5) Literature (based on factual information) reflects the various experiences, ideas, passions of ordinary people in their daily life, which helps us to investigate the values and manners of the society in a given period.

The forms of evidence developing the sub-theses of this dissertation are as follows:

(1) The constructivist theory in political science stresses the important role played by idea", -eulture" and identity" in the shaping national behaviors and national interests, which explains the formation and adjustment of Bulgarian national identity and structural changes from one culture to another.

(2) Historical accounts in Bulgaria record the nationalist efforts to reestablish the Bulgarian state, stressing their significance, both positive and negative, to the nation; the historical foreign policy positions of Russia help us to understand that the 
interaction with Other transformed the role identity of Bulgaria and consequently its national interests.

(3) Journalist resources provide as much as possible points-of-view of that time, showing the responses of the Bulgarians to the Russo-Turkish War - its background and aftermath, and the public press in its slant to influence policy.

(4) Linguistics (Linguistic innovations) enable us to see language as a unifying factor in the construction of Bulgarian national identity, as well as a weapon to resist assimilation to other nations.

(5) The literary works by Ivan Vazov offer a verbal narrative of Bulgaria at the time. His novel Under the Yoke helps us to understand the values and manners of the Bulgarians in the last decade of Turkish occupation.

\section{What is nationalism and why constructivism?}

For decades, historians have struggled to define -nationalism". What makes up a nation? The answers provided by most historians and intellectuals were short-lived. Benedict Anderson attempted to analyze the term in his widely quoted work Imagined Communities: Reflections on the Origins and Spread of Nationalism in 1983. Anderson defined nation as -an imagined political community - and imagined as both inherently limited and sovereign"6. Although Anderson's answer does take us closer to the truth, Anderson does not provide a sufficient explanation.

Before and after Anderson, many intellectuals gave their own definition with different points. For Ernest Gellner, - nationalism is primarily a political principle, 
which holds that the political and the national unit should be congruent"; it is a theory of political legitimacy"7. While Anthony Smith regarded it as a particular ideology of solidarity because he held that For nationalists themselves, the role of the past is clear and unproblematic. The task of the nationalist is simply to remind his or her compatriots of their glorious past, so that they can recreate and relive those glories."8

All these definitions are accurate in a narrow sense, but none of them offers a comprehensive explanation of nationalism. In other words, nationalism can be defined in a limited dimension. If someone intends to give a comprehensive definition, considering all aspects of the question comprehensively would be more convincing. Nevertheless, if we are interested in explicating specific events with the help of the concept, it would be easier to catch.

My purpose in studying nationalism is to explore its role in establishing a state. I focus on the Balkans because of its specific geographic location between the West and the East, and its constant national conflicts, past and present. I take Bulgarian nationalism as a case for investigation due to language convenience ${ }^{9}$. This purpose enables me to sidestep the conceptual diversity of nationalism and to limit my discussion within ethnic nationalism ${ }^{10}$, whose central tenet coincides with Johann Herder's claim for -self-determination". Given this, I am inclined to side with Herder's reclamation of the principle of cultural respect for nationalism.

Johann G. Herder's (1744-1803) contribution is his emphasis on the cultural unity of a community and the role played by folklore and other characters in its identity. 
Herder focused on the irrational and creative force of the people as a collective, das Volk. He believed that:

Humanity was something man could achieve only as a member of a nation and that nations could arrive at humanity only if they remained true to their national character, or souls. Each nation, then, by developing its language, art, literature, religion, customs, and laws - all of which were expressions of the national soul - would be working not only for its own strength and unity, but for the well-being of civilization as a whole. Each nation had a special mission" to perform in the progress of man toward humanity - the cultivation of one's own characteristics ${ }^{11}$.

In Herder's notion, every language, along with its cultural traditions, is different from every other; therefore, these cultural forms mirror the national community, which is also unique, and finally create a nation. Further, he held that language is the key element of national identity, because - in it dwell its entire world of tradition, history, religion, principles of existence; its whole heart and soul"12. Herder's notion of the modern nation-state relations was also highly influential, which claimed, the members of national collectivities should be able to determine their own future self-determination is the supreme political good - and each nation, should establish its own state ${ }^{13}$.

Care must be taken, in addition. Herder took a special interest in the development of the Slav peoples, and this interest aroused a strong national consciousness among the Slavs. He commended the Slavs as peaceful peasants, among whom a healthy and prosperous nation could best develop. Herder greatly admired the lifestyles and folk 
traditions of the Slavs. He predicted a glorious future for the Slavic peoples and encouraged them and others to collect Slavic folk poetry and information on Slavic traditions and customs. Herder was once heralded as the spiritual father of the Slav nationalism. His writings were published in many Slavic languages, and they were instrumental in stimulating national consciousness among Slavs ${ }^{14}$.

Factors such as geographic contiguity, religion, language or shared history are used by nationalism to distinguish one community from another. In other words, nationalism is linked to the ideology of what has come to be termed as Romanticism: the search for the uniqueness, for the original sources of the differences between peoples, mostly constructed around language, religion and folklore ${ }^{15}$.

In the typology of nationalism, the dichotomy of Hans Kohn is highly celebrated. Kohn advocated Western and Eastern varieties of nationalism, believing that $f$ the Western nationalist idea - at least in its idealized form - stressed universalism, rationality, and self-transcendence, the Eastern stressed particular national identities, an emotional connection to history, and development rather than transcendence." According to Kohn's typology of nationalism, the Western nationalism in Western Europe and the United States was the product of political and social factors; the Eastern nationalism, however, emerged not only in Asia, the traditionally perceived Eastern world, but also in Central and Eastern Europe. There, Eastern nationalism found its first expression mainly in the cultural field because of the backward society and politics. This classification is marked largely by the respect to Western nationalism which embodied the spirit of the Enlightenment. Western nationalism, 
whether in Britain, France or the United States, impelled these countries to establish a democratic political system, and also boosted their economic rise. Western nationalism, therefore, is positive and constructive. Eastern nationalism, however, was equated with an authoritarian uniformity of state and faith. Compared to Western nationalism, Eastern praised collective power, national unity and independence from foreign domination rather than liberty at home, or the necessity for expansion by the superior nation $^{17}$.

Although Kohn's typology leaves him vulnerable to the charge of Eurocentrism, his notion on the two nationalisms proved to be long-lived and was widely used. Specific to the region, Kohn made a persuadable argument that -Eentral and Eastern European nationalists drew on myths of the past, dreams of the future, and distinctive intellectual traditions to imagine connection with the present, and expected to become sometimes a political reality"18. Balkan nationalism is treated as one of the most drastic embodiments of the non-Western forms, and it is rooted in a cultural field rather than in political and social reality. The social and political backwardness of the Balkans, along with their dependence on the West, produced a much more emotional and authoritarian nationalism lacking self-assurance, and this inferiority complex was often compensated by overconfidence. The Balkan nationalism laid special emphasis upon myths and dreams of the future, without immediate connection with the present. Differing from the Western idea about nation - nations emerge as voluntary unions of citizens and individuals express their will in contracts, the Balkan nations were regarded as a political unit centering on the irrational, 
pre-civilization folk concept. Nationalisms in this region also found their rallying point in the folk community, and were elevated to the dignity of an ideal or a mystery; and they were mostly concerned with the diversity and self-sufficiency of nations rather than the universal similarities of nations ${ }^{19}$.

More than that, the significance and value of study on Bulgarian nationalism in this dissertation owes to the application of constructivist approach. Constructivism is one of the major schools of thought in contemporary political science, and it advocates that international relations should be examined and resolved from a sociological perspective. The most influential representative of the school is Alexander Wendt, whose masterpiece Social Theory of International Politics in 1999 presented three core concepts of social psychology - culture, identity and interest. $\mathrm{He}$ stresses the important role played by idlea", -eulture" and identity" in shaping national behaviors and national interests. Cultural theory of international politics, established by Wendt, discusses three ideal types of cultures - Hobbesian, Lockean, and $\operatorname{Kantian}^{20}$, which are based on and constitute different role relationships between states: enemy, rival, and friend. For Wendt, structural change is a move from one culture of anarchy to another, which represents the transformation of identity from one to another. This evolution of identities takes place through natural and cultural selection $^{21}$. Wendt assumes that continuous interaction among states may transform role identities of states (in other words, how they see_Self ${ }^{\star}$ and _Oher ${ }^{\star}$ by changing their ideas and therefore, role identities) and consequently, their interests ${ }^{22}$. That is, the structure leads actors to redefine their identities and interests in the process of 
interacting. On the other hand, the constructivist definition of structure in social terms suggests that human agents and social structures are, in one way or another, theoretically interdependent or mutually implicating entities ${ }^{23}$. This means that structures can be changed through acts of social and public will.

In the Bulgarian case, the history of the National Revival witnessed the structural changes, at the center of which were human activity and social practices. The Bulgarian national identity was in the process of being formed and reformed"24. The Bulgarians defined and constructed their identity according to their experiences and perceptions, in interaction with and in relation to members of neighboring nations (including Russia). In the long Ottoman rule, the people living in the lands of Bulgaria, along with other Balkan peoples, treated the Turks as the -enemy", which in turn motivated the peoples to bond with each other and form a relationship based on shared faith, culture and language, thus constructing their vague identities in a sense of Slavdom with Christian faith. The national figures of the time participated actively in the struggles of the neighboring nations and established Balkan Christian alliance against the Ottoman Empire mostly because of the similar identification of the nations.

Between the Bulgarians and the Russians, there was a bond of friendship due to the shared national properties; more importantly, Russia was also the enemy of the Ottoman Turkey because of the constant competing territorial claims. As time went on, with the conflicts between the in-group of the Balkan peoples, plus the exposure of Russia's ambitions for the Balkan region, the Bulgarian national elite adjusted the 
revolutionary strategy by switching to self-liberating actions rather than depending on external forces (including Russia). Associated to this, the Bulgarian national identity was re-constructed by highlighting their specific national features in consideration of their national interests and the instability of the relationship with the neighboring groups. In Wendt's analysis, interests presuppose identities because an actor cannot know what it wants until it knows who it is ${ }^{25}$. This is especially true for Bulgarian national identity because the factors at both domestic and international level influenced the people to construct their own order, identifying friends and enemies and acting accordingly.

\section{Historical background}

The Balkan states are newcomers in the family of European nations. Four of the five states made their appearance in the course of the nineteenth century, while the fifth did not materialize until the beginning of the twentieth. It does not follow, however, that the Balkan peoples lack a sense of historical consciousness. Precisely the opposite is the case. For over four centuries the Balkan peoples were under the domination of the Turks. These centuries became a blank in their histories, so that when they were once more free they naturally looked back to their respective periods of imperial power and glory: the Bulgarians to their Tsar Simeon, the Autocrat of the Greeks," the Serbians to their great Dushan, conqueror of most of the peninsula, and the Greeks to their Byzantine emperor, Basil the Bulgar-Slayer, or further back still, to the glories of their classical age. These traditions are alive and real, and are taken quite seriously, particularly in supporting territorial claims ${ }^{26}$.

This quotation was by L. S. Stavrianos in his work The Balkans Since 1453. The statement drives us to review the glorious past in the history of the Balkans. Bulgaria is still a case in point.

The modern Bulgarian nation was composed of the Thracians, the Slavs and the Bulgars $^{27}$. The history of Bulgaria started with the Thracians who appeared on the 
Balkan Peninsula and settled in the territories of today's Bulgaria during the Bronze Age. Here they left a rich cultural heritage - tombs, temples and treasure. The Thracians were never united. Thus by $50 \mathrm{AD}$ the Bulgarian lands became part of the Roman Empire. During the Roman rule, the Slavs started to migrate south from Central Europe, bringing their faith and culture. In the second half of the $7^{\text {th }}$ century the territory of the present-day northeast Bulgaria was inhabited by the Bulgars, who settled there and united with the Slavs and founded the Bulgarian state under the leadership of Khan Asparukh. The state was recognized by Byzantine in 681 . Meanwhile, the two tribes merged to form the first Bulgarians".

To remove the threat of Byzantine domination, the Bulgarians advanced southward led by their great Uhan Krum, and defeated a number of Byzantine armies. The Byzantine Emperor was forced to recognize the Bulgarian conquests; in return, Khan Boris, another Bulgarian leader, accepted Christianity. In 870, the Bulgarian Church was recognized as an Autonomous Eastern Orthodox Church under the supreme direction of the Patriarch of Constantinople. To convert the populace, between 860 and 863, Saint Cyril and Saint Methodius ${ }^{28}$ created the Glogolitic alphabet by the order of the Byzantine Emperor. Banished from Great Moravia, the disciples of Saint Cyril and Methodius reached Bulgaria. They found refuge at the court of Boris I. With the support of Boris, in the early $10^{\text {th }}$ century the disciples improved the Glogolitic alphabet into the Cyrillic alphabet. Later Cyrillic spread eastwards and southwards among other Slavic peoples, Russians and Serbs, and was accepted as the Slavic writing system. 
Within a short time the Bulgars were assimilated and became Slavic in everything but name. That was, during the integration of the Slavs and the local residents in the land of Bulgaria - the Bulgars and the Thracians, the latter two accepted the former's language, religion and customs, and this laid the foundation of the construction of Bulgarian nation ${ }^{29}$.

The medieval Bulgarian state reached its height during the reign of Boris's son, Simeon (893-927). He united the South Slavs, and changed Bulgaria into a great Balkan Slavic empire. He conquered Nish and Belgrade of Serbia, and seized all Slavic-inhabited lands in modern southern Macedonia and southern Albania. In addition to this, Simeon's cultural accomplishments were equally impressive. During his reign, Greek books were translated into Slavonic, and the arts and churches were patronized. All these achievements made the tenth century the Golden Age" in the history of Bulgaria.

After Simeon's death, the Bulgarian empire was soon to crumble. In the $11^{\text {th }}$ century, the First Bulgarian Empire collapsed under Russia and Byzantine attacks, and in 1018, finally became a province of the Byzantine Empire. With the cherished names of Boris and Simeon, led by the brothers Asen and Peter, the Bulgarians regained their independence in 1185, and thus formed the Second Bulgarian State. Their successor, Kaloyan (1197-1207) restored Bulgaria to the leading power in the Balkans. But the Golden Age" did not appear again. The decline of the kingdom reached its bottom with its defeat by the Serbs in 1330. Thus Bulgaria became vassal to Serbia. With the collapse of the Serbian empire, the whole peninsula, including 
Bulgaria in the hands of Serbia, was conquered by Turks, and the history of almost half a millennium of Turkish rule began.

The 500-year-feudal rule and national oppression by the Ottoman Empire distorted the original political, economic and cultural life of the Balkans. More than that, the long-time foreign domination obstructed the link of the region to the mainstream European social and economic development. The Balkans lost the opportunity of Renaissance influence and the Reformation movement; consequently, the Balkan modernization in economy, democratic thoughts and religious reform lagged behind.

After the mid-18th century, under the influence of bourgeois Enlightenment in Western Europe, the national consciousness of the Balkans awakened. The emerging bourgeois intellectuals took language as the basis for national revival, and aroused national consciousness among the people by creating national language and culture. As a result, cultural nationalism in the Balkan nations rose gradually, and the modern sense of nationalism began to appear.

\section{Why 1870 s?}

The Bulgarian National Revival (sometimes called the Bulgarian Renaissance) was a period of national awakening and national integration among Bulgarian people under Ottoman rule. It is commonly accepted that the period could find start with the publication of the historical book Slavonic Bulgarian History written in 1762 by Paisii Hilendarski (Paisii of Hilendar), and lasted until the Liberation of Bulgaria in 
1878 as a result of the Russo-Turkish War of 1877-1878.

Historians $^{30}$ stated that the periodization of the National Revival should be treated on the basis of the real changes in historical evolution. Under this principle, the first period of the Revival covered the 18th and the early 19th century, and should be called the Early Revival. During this period, the bourgeois ideology began to take shape, and the cultural and spiritual maturation in the Bulgarian society helped to form the national idea. The second period coincided with the time of the $1820-1850 \mathrm{~s}$ reforms in Turkey from to the Crimean War. During this period the deepening revival matured in some respects, in which two powerful national movements were opening - for modern education and religious independence. The third period began after the Crimean War and ended with the liberation of Bulgaria in 1878. This period coincided with the final phase of the Bulgarian Revival which ended cultural revival and spiritual formation of the Bulgarian nation.

As the last decade of Bulgarian national movement, the 1870s was the climax, a stage of organized national revolution, in which the most significant events occurred, such as the independence and autonomy of the Bulgarian Church (1870), the April Uprising (1876) and the ultimate Russo-Turkish Liberation War (1877-1878). It was also during the stage that the Bulgarian nation formally received international recognition $^{31}$

Research on the social construction of Bulgaria in this decade, including public response in press, linguistic initiatives and literary works will be valuable and necessary to the studies of Bulgarian national identity and the development of 
nationalism. Particularly, analyzing the primary sources of the time - the newspapers and archives will greatly benefit the studies.

\section{Why study Russian influence?}

Bulgaria is not Russia‘s Trojan horse in Europe." The incumbent president of Bulgaria Rosen Plevneliev said so when he talked about the political and trade relations between Bulgaria and Russia on May 20, 2012, on his visit to the U.S. The listeners, the majority of whom were Bulgarians, responded with loud applause ${ }^{32}$.

Why did the head of Bulgaria fear being considered as Russia's Trojan horse in Europe"? What kind of clues to relations between Bulgaria and Russia could be found from this negative statement? Was there some national mentality hidden behind it? Why discourse on Russia and its influence puts the Bulgarians on the defensive?

Putting political and diplomatic relations aside, relations between Russia and Bulgaria are marked mainly by their closeness in alphabet, language, culture and religion. Ethnically, the Bulgarians belong to the South Slavic group, while the Russians are East Slavs. When it comes to influence, it was by no means one-way; rather, it showed two-way interaction between the two nations in the above-mentioned areas.

From the $10^{\text {th }}$ century, both nations used Cyrillic alphabet. The Cyrillic alphabet was developed in the First Bulgarian Empire by Saint Cyril and Methodius along with their disciples ${ }^{33}$, and then spread among other Slavic peoples including Russians. The formalized alphabet was significant for the eastward spread of Christianity. In 
the mid- $9^{\text {th }}$ century, Saint Cyril and Methodius translated parts of the Bible into Old Church Slavonic language for the first time, paving the way for the Christianization of the Slavs. There is evidence that the first Christian bishop was sent to Novgorod from Constantinople, circa $866-867^{34}$.

The Russian variant of the common tradition, in return, played a crucial role in the National cultural revival. In the 1830s, when modern Bulgarian education was still in its infancy, Russian language and literature had a solid presence in Bulgarian school curriculum. The ensuing developments of modern ideas in Bulgaria, such as the emergence of nationalism, and of constitutionalism and communism, were all related to Russia‘s introduction ${ }^{35}$.

In the late 18th century and the first half of 19th century, the Bulgarians under Ottoman rule had already had some national consciousness, which could be inferred from Paisii Hilendarski‘s work Slavonic Bulgarian History of 1762. Yet due to the economic, political and military weakness, they were still not capable to regain their national independence and sovereignty from the ruling powers. Consequently, when revolts against Turkish rule broke out in the Balkans in 1870s, the Bulgarian nationalists looked to Russia to deliver them from foreign oppression. Although in historical studies much attention has been given to the relationship between Tsarist Russia and Balkan national liberation movements, less interest has been shown in the subject of the role of Russia in the formation of Balkan nationalisms and thereafter. Given this situation, one of the emphases of this project will be laid upon this discussion: To what extent the formation and evolution of Bulgarian nationalism was 
influenced by Russia and by Russo-Bulgarian relationship? The investigation will concentrate on the ideological aspect and the unique national and linguistic relationship between the two nations.

In elaborating interdependence between states, Wendt pointed out, Fear of exploitation is a genuine concern in anarchy... Knowing that other states will restrain themselves is a key condition enabling states to realize the positive effects of interdependence" ${ }^{36}$. Wendt's constructivist theory enables us to approach Russo-Bulgarian relationship in a way of international politics. Judging by historical inquiry and public responses in the press, it is easy to read that the Bulgarians were often in an ambiguous state that they suspected the original intention of Russia's helping activities, and whether Russia would restrain itself as a liberator. This reflected two sides of the Russo-Bulgarian relations - interdependent and homogeneous ${ }^{37}$ on one side, sensitive and vulnerable on the other. Russia's special and complicated identity represented in the Bulgarian question played an irreplaceable role in the development of nationalism of the latter.

I would argue that if there was no Russian influence, Bulgarian nationalism would have developed differently. Between the Bulgarians and the Russians, there was a bond of friendship due to the shared national properties; more importantly, Russia was also the enemy of the Ottoman Turkey because of the constant competing territorial claims. Therefore, as we see in the early stages of Bulgarian National Revival, Russia's involvement, either cultural or political, helped the enslaved Bulgarians to construct the national identity and establish their nationhood. To be 
specific, culturally, Russia enlightened the Bulgarian elites with translated books, lingusitic loanwords and the education of the Bulgarian emigration; at the same time, the common Orthodox faith, the Cyrillic alphabet and the Slavic traditions helped to construct Bulgarian national identity. With the exposure of Russia's ambitions in the Balkan region, the Bulgarian national elites began to restrain their trust in and the reliance on Russia for fear of being engulfed. In the aftermath of the Treaty of Berlin, the positive role of Russia in the mind of the Bulgarians was replaced by the potential danger of Russia, physical or psychical. Bulgaria, in this case, resorted to other Great Powers which were strong enough to constrain the influence of Russia in the Balkan region.

The structural change impelled the Bulgarians to reproduce their national identity. The Slavic properties, which were highlighted in the early stage of the National Revival, increasingly gave place to a purified Bulgarian identity. In other words, when the Slavonic-Bulgarian identity was contructed and helped the nation to achieve part of their national interests, the nationalists began to seek the uniqueness of the Bulgarian nation, avoiding being over-tied to the Slavic friend-Other.

\section{Methodology}

This will be an interdisciplinary dissertation which talks about Bulgaria in the period of the $1870 \mathrm{~s}$ from the perspective of political science, historiography, journalism, linguistics and literature. By working in these disciplines, this dissertation attempts to construct a unique treatment of the topic - the formation of Balkan 
nationalism and its link to Russian nationalism as fellow Orthodox Slavs.

The limitation of this research is the absence of primary and secondary sources in Russian, which reduces the possibilities of treating the bilateral relations on the basis of data from both sides. This may lead to a lack of objectivity and impartiality in analysis of some historical facts because the historical writers are always different in terms of ideology, approach of history writing, individual perspective, and personal preferences and so forth. To minimize this limitation, the author read historical resources both in English and Bulgarian, discriminating between facts and opinions so as to be closer to the historical truth. Nevertheless, this limitation cannot be eliminated completely. That is what the author needs to recognize.

As mentioned above, constructivist approach will be applied in discussing how the process and structural change" occurred factually over a period of time in the Bulgarian public world, as well as how Russo-Bulgarian relations influenced the development of Bulgarian nationalism. To achieve this, a great number of primary documents, including archives and newspaper reports will be analyzed as evidences of the topic discussion.

In this dissertation, data will be collected from both secondary sources and the primary ones. On the one hand, the data will be collected from public sources such as books, published journal articles and reports; on the other hand, the data will also be collected from archives, personal diaries of historical figures, and newspaper reports and articles. It must be noted that all primary sources used in this dissertation are in Bulgarian. The translation of these sources into English is accomplished by the 
author herself.

By employing primary sources, this dissertation is to elaborate the construction of Bulgarian nationalism. Based on these sources, this work will look at a specific period in terms of public policy - discussing political decisions, showing the public press in its slant to influence policy in the framework of constructivist theory. This section indicates one of the key periods during the Bulgarian national movements Russo-Turkish War 1877-1878 and its aftermath, analyzes and interprets the reports and articles published in Bulgarian newspapers before and after the outbreak of the war. Thus, the public response and its build-up to the war will be outlined, which would serve the thesis discussion.

The hermeneutic method will be applied to present literary taking up the perspective, i.e., interpret the representative literary work of Ivan Vazov - Under the Yoke. Under the Yoke was written by Vazov in 1888, which depicts the real life of the Bulgarians under the Ottoman rule, their suffering, their national values and their preparation for the uprising (historically April Uprising of 1876). Hermeneutics will be applied in interpreting literary work. By analyzing and interpreting the chosen text, the nature of the people's values, concerns, manners and sentiments at the time would be explored.

\section{Contribution}

Hopefully, the major contributions of this dissertation will be: 
1. It will examine to what extent the development of Bulgarian nationalism was influenced by Russia at the vital stage - the 1870 s, when the nation intensively fought against the Ottoman rule and finally achieved national liberation.

2. Constructivism will be applied to elaborate the process of structural change in Bulgaria at the time and the construction of Bulgarian nationalism.

3. Many primary sources will be used for outlining the public response to the events occurring at that moment.

4. The investigation on Russo-Bulgarian historical, political and cultural relations offers an example for future studies in how to construct a rational pattern of relationship between great powers and small nations with common faith and culture.

5. It will be an interdisciplinary research that brings political science, journalist evidences, linguistic innovations and literary expressions together into discussion, drawing a panorama of the development of Bulgarian nationalism in the time examined.

\section{Overview of chapters}

The concepts and discussions in this dissertation are not a departure from current ones. Rather, they grow out of and extend existing ones. What has been lacking in studies on Bulgarian nationalism is thorough investigation from various perspectives, namely how the Bulgarians of different spheres pool efforts to bring up the nationalism of Bulgaria. Failure to give full probation into this has prevented a 
thorough understanding of the nature of Bulgarian nationalism. To address these deficiencies, each chapter of this dissertation takes charge of specific responsibilities.

Chapter 1 begins by the review of Wendt's theory on how identities and interests are learned in social interaction, then laying out the debate on the chronology of Bulgarian National Revival and the dominating point of view. From there, the periods experienced by Bulgarian nationalism are discussed. At the beginning of the National Revival, when the Ottoman rule seemed impregnable, the Bulgarians identified themselves as underprivileged people under the enemy's domination. This identification restricted the Bulgarians from developing their national economy and culture for self-strengthening. With the awakening of Bulgarian national consciousness, some new political tendencies emerged, and strengthened were the interests to and dependency upon those forces that could be allies of Bulgaria. Meanwhile, the idea of Common-Christian and Slavic unity was also supported by the elites. At this stage, the Bulgarian nationalists believed that enemies of my enemy are my friends", participating actively in the liberation movements of other Balkan nations, as well as relying on external forces.

Chapter 2 examines Russia's impact on Bulgarian nationalistic development from political and cultural perspectives respectively. Strategically, Russia saw Bulgaria as a key link for operating in the Black Sea and the Mediterranean Sea. In Russian foreign relations all Balkan interests were subordinated to the problem of the Straits $^{38}$, the Bosphorus and the Dardanelles. Control over them was also an objective of the Russo-Turkish War 1877-1878. Since the late $18^{\text {th }}$ century, Russia struggled 
against its main rival in the region, the Ottoman Empire for expanding to the south. During this course, the Balkan national liberation movements coincided with the national interests of Russia. That is, the Balkans, particularly the Balkan Slavs like the Bulgarians, were looking forward to liberation from the Ottoman rule, while Russia precisely coveted the partition of the Ottoman lands in the Balkans, widening its influence in the region. Encouraging the Balkan national movements and offering military support was consistent with the national interest of Russia, and Russia did so. During the process, the closeness of language, religion and culture between the Balkan Slavs and Russia was pressed into service by both sides. Russia made use of these dimensions to emphasize Slavic consciousness, promoting Pan-Slavism ideology and cultivating Slavophil and Russophil attitudes? in the Balkan nations; while the Balkan Slavs (the Bulgarians) constructed their national identity within the framework of Slavonic culture (the faith in Orthodox Christianity, the language in Cyrillic script and Slavonic customs), which enabled them to regain national liberation and independence.

Chapter 3 probes deeply into the Bulgarian public policies by quoting more than 20 messages $^{39}$ from the Bulgarian newspapers of around 1870s. The author picks mostly the speeches of some national elites, represented by Georgi Rakovski, Lyuben Karavelov. Rakovski was the first ideologist and organizer of Bulgarian national liberation movement, his extensive experiences and theoretical ideas were highly inherited by the later generations in their struggle. Karavelov was a writer and an important figure of the National Revival. He contributed significantly to the 
intellectual movement of the Bulgarian community of the time. His political claims experienced a changeover from the idea of the unification of South Slavs to that of national self-liberation. The newspaper articles being examined in this chapter are mainly from the newspapers edited by the two figures - Danube Swan (Дунавски лебед) by Rakovski, Liberty (Свобода) and Independence (Независимост) by Karavelov (including a numbers of unsigned materials). Through text analysis, the pre-Liberation public opinions, the people's concerns and the response to major events could be perceived. Prior to the organized revolutionary movement, the Bulgarians attempted to separate their Church from the domination of the Constantinople Patriarchate. In order to suppress the negative attitude taken by Russia on the independence of the Bulgarian Church, Bulgaria turned to other Western Powers for help. The Church issue always put the Bulgarian press on the defensive even after Bulgarian Exarchate" was restored by a decree of the Sultan in 1870. The debate on the preparation of revolution in the press focused on the either-or situation - to count on the Great Powers or on self-strength, which also involved expectations and suspicions towards Russian aid. The controversy between these two philosophies showed public confusion, which might be one of the reasons for the lack of revolutionary preparation. The public responses to Russo-Turkish War 1877-1878 and its aftermath reflected that the Bulgarians were grateful to the liberation and independence brought by Russia, and to a greater degree, however, they feared being actually controlled by Russia. 
Chapter 4 investigates how language served as a fostering force and weapon in the construction of Bulgarian national identity. The elimination of effects of Greek language enabled the Bulgarians to be independent from Hellenistic cultural domination, thereby pushing the national development forward. In shaping the modern Bulgarian national literary language, the place of Russian cannot be underestimated, especially in the lexical aspect. A large number of Bulgarian national lexicons were derived from the Russian language. Importantly, the new concepts related to the development of social and cultural life contained in these loanwords were also accepted by the Bulgarians. These loanwords introduced modern European values to the nation. Whereas linguistic purists like Ivan Bogorov defended with passion the purity of Bulgarian in the attempts to reduce Russian and Greek influence on it by introducing a number of rare dialectal words and neologisms to the literary language. This proposition embodied the nationalistic effort to maintain the purity and independence of Bulgarian nationality.

Chapter 5 provides insight into the nationalistic sentiments of Bulgaria in the time specified above by interpreting Ivan Vazov's novel Under the Yoke. The novel portrays war, rebellion and romance in Bulgarian lands under the Turkish rule. The characters such as Ognyanov, the protagonist, Rada and Stefchov are portrayed in black and white, which represents the value of good and evil, Self and enemy, Bulgarian and alien, etc. the loyalty of Ognyanov, Rada and Sokolov and their willingness to die for the revolutionary cause embodies Vazov's nationalistic intention to shape the morals and values of the new Bulgaria. The author always 
reminds the Bulgarian people in a subtle way what it means to be Bulgarian, paying respect to Bulgarian tradition and culture, while at the same time calling for a revolution. It is credited with helping to shape and solidify the national identity and nation mentality.

Chapter 6 sums up the research findings previous chapters, showing a whole picture of the fluidity of Bulgarian national identity in the process of structure changes between the late $18^{\text {th }}$ century and 1870 s. Summary statement is also given in terms of how the identity of Russia was constructed and the role Russia had taken in the evolution of Bulgarian nationalism. In this section, the dichotomy approach of Hans Kohn to separate the good nationalism from the bad by using geographical criteria, making conclusion that we have to go beyond the good" and bad" to understand nationalism in its many facades and stages of development.

\footnotetext{
${ }^{1}$ The Britons. - The author's note.

${ }^{2}$ William Gladstone (1876): The Bulgarian Horrors and the Question of East, London: J. Murray, http://www.attackingthedevil.co.uk/related/bulgarian horrors.php, accessed on Aug. 6, 2013.

3 As cited in Georgi Todorov: The Liberation of the Bulgarian-Russian Relations. http://www.kultura.bg/media/my html/2018/georgi.htm, accessed on May, 20. 2013.

${ }_{5}^{4}$ Kenneth Lantz (2004): The Dostoevsky Encyclopedia, Greenwood Publishing Group, p. 399.

${ }_{6}^{5}$ Ibid, p. 79.

${ }^{6}$ Benedict Anderson: (1983/1991) Imagined Communities: Reflections on the Origins and Spread of Nationalism, 1st and revised editions, London and New York: Verso, 1991, p. 5.

${ }^{7}$ Ernest Gellner: Nations and Nationalism. Ithaca: Cornell University Press, 1983, p. 1.

8 Anthony Smith: Gastronomy or Geology? The Role of Nationalism in the Reconstruction of Nations", Nations and Nationalism 1, No. 1 (1994), p. 18.

9 The author reads only Bulgarian out of the Balkan languages. For being closer to the native-language sources, the focus of this dissertation is narrowed down to Bulgarian case.

${ }^{10}$ As a form of nationalism, ethnic nationalism is often paralleled with civic nationalism. The former defines nationhood by language, religion, customs and traditions, while the latter by common citizenship and shared political values, regardless of ethnicity.

${ }^{11}$ Cited in William A. Wilson: Herder, folklore, and Romantic nationalism. Journal of Popular Culture 6 (Spring), 1973, p. 823-824.

${ }_{12}$ Leigh Oakes, Language and National Identity: Comparing France and Sweden. (in the series of Impact: Studies in Language and Society, Vol. 13, Amsterdam: John Benjamins, 2001.

${ }^{13}$ Özkırımlı, Umut: Theories of Nationalism: A Critical Introduction. New York: St. Martin‘s Press,
} 
2000, p. 19.

14 Wilson, William A. (1973) Herder, Folklore, and Romantic Nationalism. Journal of Popular Culture 6 (Spring), p. 830-831.

${ }^{15}$ Such a review owes to Maria Todorova's investigation on ethnicity and nationalism. See Maria

Todorova: Language in the Construction of Ethnicity and Nationalism: The Bulgarian Case.

Nationalities Affairs, 28/2006.

${ }^{16}$ Hans Kohn: The Idea of Nationalism: A Study in Its Origins and Background, New York: The

Macmillan Company, 1944, p. xxxiii.

17 This analysis owes to . zkırıml, Umut in Theories of Nationalism: A Critical Introduction. New York: St. Martin's Press, 2000, p. 42.

${ }_{18}^{18}$ Hans Kohn: The Idea of Nationalism: A Study in Its Origins and Background, 1944, p. 330.

${ }^{19}$ Ibid, p. 41-43.

20 Alexander Wendt (1999): Social Theory of International Politics, Cambridge University Press, p. 246-311.

${ }^{21}$ As cited in Yucel Bozdagloglu: Constructivism and Identity Formation: An Interactive Approach, Review of International Law and Politics, Vol. 3. No. 11, 2007, p. 129.

${ }^{22}$ This summary owes to Yucel Bozdagloglu in his paper - Eonstructivism and Identity Formation: An Interactive Approach", p. 129.

23 Alexander Wendt: The Agent-structure Problem in International Relations Theory, International Organization, Vol. 41, No. 3, 1987, p. 338.

${ }^{24}$ Carol Atkinson: Constructivist Implications of Material Power: Military Engagement and the Socialization of States, 1972-2000, International Studies Quarterly, Vol. 50, No. 3, 2006, p. 534. ${ }_{25}$ Alexander Wendt: Social Theory of International Politics, Cambridge University Press, 1999, p. 231.

${ }^{26}$ L. S. Stavrianos: The Balkans since 1453, New York: New York University Press, 2000, p. 15.

${ }^{27}$ Also named Proto-Bulgarians. The Bulgars are one of the three tribes which composed the modern Bulgarians. Many intellectuals and scholars prefer to the name of Bulgars" when they talk about the history of Bulgaria either because the modern Bulgarian state appeared relatively late or because they equate the two names. The author of this dissertation distinguishes the two names according to the consensus of the Bulgarian academic world - the name of Bulgars" is the modern term used by historiography for the purpose of making difference between the Ptoto-Bulgarians who came from the Central Asia to Europe in $4^{\text {th }}$ century AD and the Bulgarians who formed Bulgarian ethnic community in $9-10^{\text {th }}$ century.

${ }^{28}$ Saints Cyril and Methodius were Byzantine Greek brothers born in Thessaloniki in the $9^{\text {th }}$ century. They preached Christianity among the Slavic peoples. They received the title -Apostles to the Slavs" due to their influence upon the cultural development of Slavs.

${ }^{29}$ Ma Xipu: The History of Bulgaria, Beijing: China Social Sciences Press, 2011, p. 15.

${ }^{30}$ In History of Bulgaria 15-19 $9^{\text {th }}$ Century, the author discussed about the periodization of the Bulgarian national revival, offering sufficient arguments. See details in p.293-296.

31 Tsvetana Georgieva \& Nikolai Genchev: History of Bulgaria XV-XIX, Sofia: Anubis, 2006, p. 293.

32 This news report is quoted from both Natural Gas Europe Daily and Sega Net of Bulgaria: http://www.naturalgaseurope.com/bulgaria-russias-trojan-horse, accessed on Aug. 15, 2013; http://www.segabg.com/article.php?id=601344, accessed on Sep. 23, 2013.

${ }_{33}$ Such a view owes to both Bulgarian and Western intellectuals. Refer to: Ivan G. Iliev. Short History of the Cyrillic Alphabet. Plovdiv. 2012; Paul Cubberley (1996) "The Slavic Alphabets". In Daniels and Bright, eds. The World's Writing Systems. Oxford University Press.

${ }^{34}$ Refer to The Religion of Russia", Catholic Encyclopedia, New York: Robert Appleton Company, 1913.

35 In Chapter V, there will be a detailed discussion on the fact that some European modern values were introduced to Bulgaria through the medium of Russian loanwords.

36 Alexander Wendt: Social Theory of International Politics, 1999, p. 348-349.

${ }^{37}$ Wendt sees Homogeneity" as one of the four efficient causes (interdependence, common fate, homogeneity and self-restraint) of collective identity formation, that is, members categorize themselves as being alike along for the dimensions that define the group, and as such the perception of 
homogeneity helps constitute collective identity (Wendt 354).

${ }^{38}$ Charles Jelavich: Tsarist Russia and Balkan Nationalism: Russian Influence in the Internal Affairs of Bulgaria and Serbia, 1879-1886. 1958. p. 3.

39 Until 1890s, Bulgarian press most often used the genre of izvistie, which literally means message" or fnotice". As a genre, i zvestie places emphasis on the novelty of news, and is far shorter than article and report. 


\section{CHAPTER 1 THE PROCESS AND STRUCTURAL}

\section{CHANGE THROUGH NATIONALIST EFFORTS - $1760 s-1870 s^{1}$}

Alexander Wendt states that -anarchy can have at least three kinds of structures at the macro-level, based on what kind of roles - enemy, rival, and friend - dominate the system",2, and calls these structures Hobbesian, Lockean, and Kantian. He explains structural change as a move from one culture of anarchy to another, and this evolution of identities takes place through natural and cultural selection"3. This process of structural change may be slow, but even the most embedded structures can be altered by acts of will ${ }^{4}$. That is to say, structures are not reified objects that actors can do nothing about, but to which they adequately respond. Wendt also assumes that continuous interaction among nations and states may transform role identities of nations. As the above discussion implies, in the course of interaction at a given time and place, national identities are not fixed but fluid, changing according to subjective evaluation by individuals and groups. Thus, the identities and interests (properties) of the agents are assumed to be in process; or rather, identities are always in the process of being defined and redefined in the interaction with other nations.

This chapter applies the constructivist theory in examining how the structure leads Bulgaria to define and redefine its national identity and interests in the process 
of interaction. In other words, how they see Self"“ and -ther" by changing their ideas and therefore role identities. ${ }^{5}$

It is worth noting that the constructive analysis can only be conducted by integrating the factors operating at both domestic and international levels. As one scholar rightly points out it is commonly acknowledged that in order to understand the preferences and behavior of states in international relations, we need to take both domestic considerations and international considerations of states into account" This is particularly true for national identity since both domestic and international factors play significant roles in identity construction. It requires showing the spiritual and material conditions in which the national identity was formed, and how it was formed at the domestic level and how it, once formed, influenced national interests and behavior at the international level.

I show in the sections below four phases of Bulgarian nationalist thinking between the late 1700s and the Russo-Turkish War (1877-1878) the structure changed through nationalist efforts:

1. From the late 1700 s to the early 1800 s, Bulgarian national consciousness began to reawaken with the development of the bourgeois economic relations. Some new revolutionary ideas emerged in the resistance against the Ottoman rule.

2. From 1820 s to the early 1860 s, the Bulgarian national elites came to the idea of resort to the external assistances in order to achieve the Bulgarian liberation. They actively participated in the liberation movements of the 
neighboring Balkan nations with the hope to unite the Balkan Southern Slavs against the Turkish tyranny. Also, they expected the rescue of the Russian troops.

3. From the late 1860 s to April Uprising (1876), the political idea of Balkan federation was abandoned in favor of an ethos of self-strengthening and self-liberating. The national activists reoriented the revolutionary tactic to independent armed revolt.

4. After the defeat of April Uprising, the Bulgarians ' confidence to liberate the nation by their own strength was punctured. To achieve the national ends, Bulgaria needed always strong patrons. With this in mind, the national elited resorted to the Great Power and took part in the military actions of the Russian army in the course of Russo-Turkish War 1877-1878.

To explore the evolution of Bulgarian nationalism, it is necessary to figure out the exact beginning of the Bulgarian National Revival. Some of the first figures of the age themselves (V. Aprilov, G. Rakovski) set the beginning in 1830s, when some visible reforms started to be introduced in the Ottoman Turkey. Afterwards, M. Drinov in his article Father Paisii, his time, his history and his disciples" (1871) connected the beginning with the advent of the Slavonic-Bulgarian History by Paisii Hilendarski (1722-1773). Drinov's idea, based on the belief that the great figure could spark a new era in history, proved to be lasting. Since then, although there exist different opinions, the beginning of the Bulgarian National Revival is often associated with the efforts of Paisii Hilendarski, particularly with his endeavor to 
enlighten his people through writing the Slavonic-Bulgarian History. In the milestone work, Hilendarski sought to raise the consciousness of Bulgarians by arousing their self-respect to the national past and cultural traditions. The nationalists who superseded Hilendarski by generation developed this idea to a much more sophisticated degree. They believed that nationalism is the - ...natural and universal ordering of the political life of mankind, only obscured by that long, persistent and mysterious somnolence"7.

\subsection{Bourgeois economic relations and new political ideas in the resistance against the Ottoman rule}

An economic downswing of the Ottoman Turkey, exacerbated by the fact that the central Ottoman government had ineffective control over its own authorities in the provinces, triggered disturbances ${ }^{8}$, giving rise to the bourgeois economic development. The establishment of the bourgeois economic relations provided essential conditions for the spiritual and cultural revival of the conquered populations.

The historical process of the Bulgarian National Revival could be grouped into several partitions. First of all, there were changes in the material-economic relations, which gave way to the bourgeois merchandise-money relations. As a consequence of economic development, the structure of underdeveloped bourgeois society was established in Bulgaria. At the same time, changes in the cultural and spiritual realm found the most vivid expressions in a powerful movement for modern secular 
education. Along with this, the spiritual rebirth occurred during the continuous fight against the Greek ecclesiastical authority for national emancipation. The main result of the development of economic, social and cultural processes was reflected in the formation of the Bulgarian nation. On the basis of the Bulgarian nation, the three classic provinces Moesia, Thrace and Macedonia during the Middle Ages and the Ottoman stage, a Bulgarian national community bonded by the Modern language and culture was established.

The main content of the Bulgarian Revival was expressed in the historical transition from the Middle Ages to the bourgeois time, in the development and strengthening of bourgeois economic and social relations, in the creation of the unique national culture, as well as in the formation of the Bulgarian nation. Bulgarian National Revival was a unique synthesis of cultural-spiritual, political and ideological achievements of the bourgeois era. In this synthesis national-bourgeois revolution ${ }^{9}$ was realized.

Thus, the social, spiritual and political revolution in the history of Bulgaria appeared as an organic whole. Due to the historical conditions in which the Bulgarian Revival was accomplished (foreign political and spiritual rule and strong claims for Bulgarian historical legacies), the national idea was getting dominant from 17 th century. The main goal of the time was the political coup reflecting urgent needs of Bulgarian society, namely the liberation of Bulgaria from the centuries-old oppressors.

The historical evolution of Bulgaria during 18th through 19th centuries was 
closely interwined with the history of the Ottoman Empire, with the centuries of slavery, from which the Bulgarians suffered after Bulgaria fell under Ottoman rule in $1396^{10}$. The beginning of the Revival, armed with the ideas of the bourgeois era and started in the bowels of the Ottoman Empire to build a new culture entirely different from what was observed in the first centries of Ottoman rule, could be found when new societal forces on the basis of nation emerged. The decline and decentralization of the Empire had a positive impact on the lives of the enslaved population.

The new bourgeois relations penetrated the Empire, which caused qualitative economic and social developments in the Christian provinces, including Bulgaria. Large traders formed the core of reviving bourgeoisie, who had the highest social consciousness. Among them came out the representatives of national intelligentsia with higher education. They created the first political and cultural organizations. Most of the commercial bourgeoisie, however, were living abroad, and therefore, could not directly perceive problems inside Bulgaria.

Due to the absence of the Bulgarian state, the national ecclesiastic and cultural organization, Bulgarian bourgeoisie had been formed without strong social foundation. The majority of the group were undereducated. Its sphere of activity Wallachia, Moldavia, southern Russia and Constantinople limited its international connections within a small area, being devoid of extensive business and political contacts with Europe.

Despite its economic weakness, political immaturity and cultural backwardness, Bulgarian bourgeoisie spread the ideas of Western bourgeois epoch - Renaissance 
and Enlightenment, liberalism and nationalism. It challenged and led the movement for a new national culture and education, funding Bulgarian spiritual and political endeavors.

After the Crimean War 1853-1856, as the winner of the war, the Ottoman Turkey was officially recognized as an integral part of the European community, and thus removed for some time the main threat to Turkish existence - Russia. But the changes of the international situation could not stop the processes of disposition, which inevitably led to the collapse of this multinational state. Meanwhile, the Bulgarian bourgeoisie imposed its hegemony in the social and political development of Bulgaria ${ }^{11}$. As will be seen below, it guided the national liberating movement and, to a certain degree, directed the movement to decisive actions for resolving the Bulgarian issue.

As is mentioned above, the foreign conquest interrupted the natural development of Bulgarian society. It dealt a fatal below on the Bulgarian nation by destroying part of the democratic potential and the entire aristocracy. Social degradation led to enormous distortions of the Bulgarian nationality. Incidentally, the greatest impact on nationality was noted as slave mentality - meekness, obedience, avoidance of social life, etc. Specially, centuries of being ruled were a period of unprecedented degradation for the Bulgarian nation.

In these conditions, the bourgeoisie became the radical element in the society. Its industrial, trading and spiritual activity formed visible and invisible threads that united the nationality. As a class, it possessed revolutionary ideas, the political 
radicalism of modern cultural standards, as well as the national ideals. Without bourgeoisie and its social manifestation, there would not be a Bulgarian nation as a whole $^{12}$. Therefore, the degree of development of the bourgeoisie determined the spiritual intensity of national processes. At the same time, due to slavery, the Bulgarian bourgeoisie was politically immature, with neither diplomacy nor serious contacts with the European world. All this imprinted on both mentality and spiritual features of the Bulgarian nation.

With the awakening of Bulgarian national consciousness, some new political tendencies emerged. The dependence on the allies of Bulgaria was increasingly strengthened. Meanwhile, the idea of Common-Christian and Slavic unity also found many supporters, who found the Bulgarian national identification in the features and properties in common with other Balkan Slavs. All of these ideas created a new kind of self-confidence that the prospect of restoring the Bulgarian state would be hopeful.

Nevertheless, these new thoughts in Bulgarian society did not succeed in application. In spite of that, the Bulgarians still rested the hope of being liberated on the rescue of Christian Europe.

In this condition, Father Paisii Hilendarski and his work Slavonic-Bulgarian History were rightfully regarded as an important impetus for the formation of the Bulgarian national consciousness. During the long term Ottoman rule, Bulgaria had lost its sense of community, and to most of the people, homeland meant their own small town or village. Bulgarians had had great hisotry and great kings, but few knew about their brilliant past. 
In his Slavonic-Bulgarian History, Hilendarski stimulated the Bulgarians to prize their own history and learn Bulgarian language:

So I wrote down for you what was known about your race and language. Read and know so that you would not be ridiculed and reproached by other tribes and peoples... I wrote it for you who love your people and Bulgarian fatherland, and who like to know about your people and language ${ }^{13}$.

Without creating a new ideological system, Paisii succeeded in processing the ideas of modern time by using his patriotic ideas. In this sense, his worldview and political concepts had bourgeois character. When Bulgarian society as a whole was still under the yoke of foreign domination and the nascent national consciousness dominated the people, the awakening bourgeois nationalism satisfied the interests of the whole society, and became a powerful weapon for national emancipation ${ }^{14}$.

From the mid-18th century, political movements began to grow. This happened because the living conditions and social circumstance of the Bulgarians were increasingly worsening - the concentration of local government in the hands of the Turkish aristocracy, exorbitant tax levies and military oppression against the Bulgarians. Under the Turkish tyranny, bandit gangs of so-called kardjalii ${ }^{15}$ and daalii appeared in the Bulgarian lands, plundering towns and villages of Rumelia. The Bulgarians suffered from łardjalii times" when Bulgarians either sought refuge behind the city walls or armed themselves in cooperation with government and local warring parties to protect their villages and estates. Rakovsky wrote that in the time of kardjalii, the people in Bulgaria were all armed and many towns and large villages were surrounded by walls and trenches to protect themselves from attack of kardjalii". Thus, for the first time under the Ottoman rule, the 
Bulgarian people felt the power of arms in their hands, which was going to have a strong political and psychological impact on the further national struggle of the Bulgarians.

The Russo-Turkish wars consecutively in 1768-1774, 1787-1791 and 1806-1812 were significant for political awakening of the oppressed Bulgarians. In the first war, the Russian Empress Catherine II sent missionaries among the South Slavs, including a Bulgarian in Russian service, Colonel Korazin to spread the appeal among the oppressed for general war against the Ottoman Empire. Catherine's appeal stirred the hopes of the South Slavs for early liberation. Moreover, the Treaty of Kuchuk Kainarji $^{16}$ signed between Russia and Turkey in 1774 had a stronger impact in Bulgaria. According to the treaty, the Ottoman Sublime recognized Russia's right as the patron of Christians and agreed with the openning of Russian Orthodox Church in Constantinople $^{17}$. In the late 18 th century, when the Treaty of Jassy ${ }^{18}$ of 1792 granted semi-independence under the auspices of the Russian Emperor, the faith of the Bulgarians that they would be liberated with the help of Russia strengthened further. This belief was strengthened by the Balkan projects of Catherine II, who impressed the Bulgarians with the idea of Christianity's protection.

\subsection{Participation in the liberation movements of Balkan "friends" and expectation of rescue from "big Brother"}

In the early 19th century, a series of large shocks changed the visage of Europe and the Balkan status quo. The first half of Alexander's (I) reign witnessed the 
exacerbation of Russo-Turkish conflict which led to the Russo-Turkish war lasting from 1806 to $1812^{19}$. It was succeeded by Napoleon's invasion in Russia, the defeat of the French army, the Congress of Vienna 1815 and its preserving the balance of power in Europe. These changes crystallized the concepts of East and West within the scope of the Balkans, based on which the political doctrines of the so-called Eastern Question, encompassing the diplomatic and political problems posed by the decay of the Ottoman Empire, came into being.

International turmoil caused the domestic balance of the Ottoman Turkey to be distorted. The Serbian Uprising of 1804 broke out and achieved success; the Greek liberation revolution of 1821-1828 followed. In this situation, to establish a new political idea was particularly necessary to the Bulgarian ongoing revival movement. But this did not happen for several reasons. Above all, Bulgaria still had an anemic national bourgeoisie, which was still in the realm of Greek economic, political and cultural influence, making the first steps to its maturity. This led directly to the lack of well-prepared and educated national intelligentsia. Bulgaria continued to live in national isolation, trying to escape from kardjalii unrest. However, the new situation was not unnoticed for Bulgarians. Among them appeared clearer political intentions in comparison with that of the 18 th century. The chief idea was to settle the Bulgarian question with Russia‘s help during the war from 1806 to 1812.

Even before the war, Bulgarian leaders of Vratsa and other northwestern Bulgarian cities had established contacts with Russian reconnaissance missions in Wallachia and the consulates in Bucharest and Vidin. In 1804 two citizens of 
Vratsa-Zambin and Nikolaev were sent to Russia for the first Bulgarian diplomatic mission. With the support of the Wallachian Bulgarians and Sofronii Vrachanski ${ }^{20}$, two missionaries reached St. Petersburg and were received in the Ministry of Foreign Affairs, where they transmitted message from Sophronii, proposing that the Bulgarians join the Russian Empire. In 1812 Sofronii delivered Appeal to the Bulgarian people", urging his compatriots to meet the Russian troops as liberators, not to serve the Turkish oppressors. The Appeal indicated that the Bulgarian public figures came to the idea of combining external assistance with actions of the Bulgarian liberation movement.

In result of the activity of Sofronii and the Bulgarians in the Russia army, created in Wallachia were numerous Bulgarian squads which formed a separate fighting unit called Bulgarian Land Force". In central and northeastern Bulgaria, provisions were prepared for the advancing of the Russian army. When Russian troops were advancing towards the city of Tarnova and Sevlievsko, many Bulgarians took services in Russian army. In Gabrovo almost the entire population were mobilized and fought along with Russian detachments.

Besides the participation in the Russo-Turkish wars, the Bulgarians intervened actively in the national liberation movement of other Balkan peoples. When the Serbian national uprising broke out in 1804, the western Bulgarians living together with their Serbian brothers were spontaneously included in the squads of Kara George $^{21}$. Following the start of the Russo-Turkish War in 1806 the Bulgarian participation in the Serbian uprising not only was intensified, but began to acquire an 
organized character. On the western Bulgarian lands adjacent to Serbia, mass riots were raised. Several Bulgarian detachments commanded by Hajduk Velkf, Condo and others joined the Serbian insurgences.

The Bulgarians participated more widely and actively in the Greek Revolution in 1821-1827. The Bulgarian bourgeoisie, with its significantly strengthened economy, funded willingly the training of revolutionaries. The emigration bourgeoisie in Wallachia and Southern Russia also stood on the side of the rebellion.

The real motivation for Bulgaria's participation in Serbian and Greek uprising, as I see, came down to the common fate which had been linking the Balkan peoples for centuries, as well as in strong Greek influence on Bulgarian bourgeoisie and intelligentsia. Most importantly, Bulgaria's participation in the liberation struggles of other Balkan nations in the early 19th century was of significance for shaping the political principles of the Bulgarian liberation movement. During the Serbian revolt and afterwards, the idea of Serbo-Bulgarian political union crystallized into a more definite plan which was attempted as a real political force in many subsequent events. Greek Revolution, conversely, did show the Bulgarians politically how to organize military action. From the Greek Revolution, conversely, the Bulgarians learned the heterism tactics to create military formations and transferred them to their own country. This tactic was used later in the Bulgarian liberation movement, exerting influence upon the political view of George Rakovski.

In the second quarter of the 19th century, the Bulgarian liberation revolution began to follow the path of independent armed struggles. A number of armed 
struggles against the Turkish rule were breaking out: rebel and liberating actions during the war of 1828-1829 and its continuation - Tarnovo events of 1835 , rural uprisings in western and northwestern Bulgaria in 1835-1841, Brailska riots of 1841-1843 and Vidin uprising in 1850. These events were armed protests against uncontrolled greed and excess inflicted on Bulgarian peasants at the time ${ }^{22}$.

The rural uprisings from 1835 through 1850 were of political and psychological significance for the development of the national liberating struggle of the Bulgarian people, because they gained valuable experience in the organization and tactics of revolt.

The Crimean War (1853-1856) caused a strong reaction in Bulgaria, supported by the hope that the hour of Bulgarian liberation was finally coming. Rakovski wrote: when Prince Menchikov came, the entire enthusiasm was kindled in our Bulgarian people and Bulgarians were joyfully waiting for and confident of their liberation from the Turkish yoke."23 The Constantinople Bulgarians submitted an application to the Russian Tsar, in which they insisted on the independence of the Bulgarian Church, worship in their native language and the right to open schools. To this end, the Constantinople Bulgarians wanted Nicholas I to advocate for the liberation of Bulgaria.

With the arrival of Russian troops in the Danubian Principalities, the Bulgarian municipalities in Bucharest, Galati, Braila and other cities petitioned the Russian Tsar with similar claims. This marked the beginning of the immigrant movement in January 1854, which found an organization form in establishing the Bucharest 
Committee $^{24}$. With the permission of the Russian commanders, the Committee had an immediate task to gather volunteers to participate in the war against Turkey, to maintain permanent relations with the Russian military headquarters by their authorized representative, as well as to guide the participation of Bucharest traders in regulating the future liberated Bulgaria. The Odessa Bulgarian Trustee established in February 1854 was formed under the same conditions and with the same tasks.

As a result of the efforts made by the two organizations and other immigrants, a volunteer movement was promoted widely among Bulgarians. The preparations for struggles were still largely inadequate, both among the emigration and domestic people. In spite of this, the main result of the war for Bulgaria was that the foundations of political union between the bourgeoisie emigration and Russia was established. The union played a role of accelerating the spiritual and political maturation in the future political struggles.

The beginning of the organized national movement in the $1850-1860$ s was associated with the name and work of George Rakovski. In the first period Rakovski did not have clear views on the Bulgarian liberation movement. After the Crimean War, he was convinced that the Bulgarian liberation would go forward by means of press and sword”. In 1858 Rakovski took to summarize his revolutionary experience, developing his first plan for the liberation of Bulgaria. Bulgarians need to gain their freedom which had been lost for centuries," the experienced thinker said so in the first plan, and justified his idea of the Bulgarian people's uprising, in which the entire people should be involved - the rich with their money, the scholars with their 
writings and all the sons of the people at the cost of their lives. This idea became the core of national revolutionary ideology, policy and strategy. The people's uprising by Rakovski was to be organized by a united center to be associated with liberation struggles of other Balkan nations, as well as to be supported by the Great Powers.

In the early 1860s, Rakovski's idea about radical armed revolution in the Bulgarian liberation movement was maturing. After the Belgrade events of 1861-1862 25 , Rakovski understood thoroughly the shortsightedness of restricted nationalism that divided the Balkan peoples in the face of their common enemy. But he did not give up his ideas of Balkan Christian alliance against the Ottoman Empire because he perceived that the Bulgarians' self-armed action was still impossible in this period. Then, inspired by the Serbian government, he embarked on a new mission for the unification of the Balkan peoples. But his mission met again the resistance of Balkan nationalism, and thus failed. Rakovski rethought the historical experience of his revolutionary career and concluded that Balkan nationalism was an insurmountable barrier to his imagined liberating union and Bulgarian liberation could rely only on their own strength. Therefore, Rakovski proposed independent revolutionary action instead of confederation of the Balkan countries. At the end of his life, he came to the idea of autonomy and independence of the Bulgarian revolution.

Rakovski was a unique phenomenon in the Bulgarian national history because his ideology and political proposals coincided with structural changes of Bulgarian national liberating struggles. Among his contemporaries, he was the first to have an 
insight into the historical necessity of a revolutionary solution to the Bulgarian question by an organized struggle for liberation. He came up with the idea of armed uprising cooperating with the neighboring Balkan countries, which could lead the liberating struggle to the victorious end. He, as a politician, was the first to discern that the Bulgarian issue was part of the Eastern Question, and Bulgarians should make use of conflicts between the Great Powers to realize their political aspirations. Rakovski much understood Russian politics. Since there were many commnon interests between Russian politics and the Bulgarian liberation movement, Rakovski hoped Russia would offer the Bulgarians some help. But he was well aware of the hidden ambition of Russian tsarism in the Balkan region, thus opposed and attacked the doctrine of the Eastern Christians' unity ${ }^{26}$.

\subsection{From reliance on external forces to action of internal self-liberating}

Since the death of Rakovski in 1867, the new leadership of the Bulgarian liberation movement carried over Rakovski's work of preparing for revolution. The outstanding politicians were Ljuben Karavelov and Vasil Levski. The former followed Rakovski‘s ideologies in his early career and represented a Slavophil and educator, attracted by Count Ignatiev to his project of creating a Slav state. At the end of 1869 , the Bulgarian Revolutionary Central Committee (BRCC) was established in Bucharest, which responded to the historical necessity of creating a center of the national struggle. Karavelov became one of the central leaders of the Committee. In 
the first program, published on August 1, 1870, Karavelov determined the two enemies of Bulgarian people - the Turkish government and the Greek clergy. And the Turkish government, in his idea, was regarded as the main enemy of the Balkan peoples' liberty and progress. Moreover, he considered the national revolution to be part of the Pan-Balkan liberation, and therefore, to cooperate with other Balkan nations would guarantee the success of the Bulgarian undertaking ${ }^{27}$.

After the failure of a set of political and revolutionary attempts, Karavelov began more definitely to take up the idea of Hiberation through education". Because BRCC and Karavelov did not reach an agreement on the issue of independent Bulgarian revolution, they oriented the revolution to a united Balkan action.

Those who had experienced failures of revolution understood the futility of political alliance in the condition of the rising Balkan nationalism. They gradually departed from the Committee to seek more radical measure for political liberation of Bulgaria. At the head of this group stood Vasil Levski.

Influenced by the revolutionary ideas of Rakovski, Levski continued to seek new ways of liberation. He and Karavelov participated in the establishment of BRCC. Their common idea to prepare for the liberation of Bulgaria by internal revolutionary organization was implemented in the following actions.

Within the two years from 1870, under the leadership of Levski, established in the country were unban and rural revolutionary committees, the number of which was imponderable. Thousands of Bulgarian merchants, artisans, peasants, teachers and priests were involved in the Internal Revolutionary Organization (IRO). The people, 
for the first time in the history of liberation struggles, held the destiny of Bulgaria in their own hands ${ }^{28}$. Levski rejected political alliance with foreign powers because he believed that it had brought and would bring failures and sufferings Levski firmly called for political emancipation of the Bulgarian Revolution. In a letter to P. Hitov in September 1871, he strongly warned the emigration that they could not negotiate with foreign countries on behalf of the Bulgarian movement, and that the revolution could rely only on the people's strength. Firstly, we should fix the inner work, after that we could pray for more" 29 , wrote Levski. Having the same thoughts, Levski rejected the proposal of $\mathrm{H}$. M. Toshkov from Odessa to seek the political assistance from the Russian Emperor.

Levski advocated radical bourgeois democratic views. He defined the major goal of the liberation struggles in the draft project of the revolutionary organization composed by him in 1871, in which he wrote-to create an essential transformation of the current despotic and tyrannical system and to replace it with a democratic republic (managed by people)". The future democratic republic, according to Levski would fully guarantee the freedom of thought and speech, and of press and organization as well. In the future Bulgarian state, Bulgarians, Turks, Jews, etc., will be equal in any respect, regardless of faith, nationality or civil rights. Everyone will behave under a general law being chosen by majority of each nation." 30

After the establishment and strengthening of BPO, through 1870 to 1871 two centers of Bulgarian revolutionary movement were formed - demostic led by Levski who expressed Bulgarian society's radical tendencies towards liberty and 
independence by revolutionary democratism, and Bucharest center lead by Karavelov who was engaged in revolutionary propaganda, as the liberal wing of revolution. Both centers, however, had the same task - to advocate the liberation of Bulgaria by national revolution. But they differed in their understandings of the organization and tactics of revolutionary action. They tried to get closer and to find a compromise to coordinate their actions, but they failed to do so. The unity of IRO was threatened, which showed a sign of decay. In December 1872, when Levski moved to Bucharest for defending his beliefs, he was captured by the Turkish police. The court sentenced him to death, and on February 6, 1873, Levski was hanged in the suburb of Sofia.

Levski's death caused a deep crisis in the Bulgarian revolutionary movement in terms of ideology, politics and organization. Karavelov started to lose his hopes to the idea of self-liberation developed by Levski. He turned again to foreign help, particularly the help of Serbia. Therefore, in 1873 he went to Belgrade to seek an agreement with the Serbian government. Later he, for the same purpose, discontinued his newspaper Independency because the newspaper was the organ of independent Bulgarian revolutionary movement, and the Serbian politicians were not satisfied with the main direction of it.

Karavelov announced his rejection of participating the Bulgarian revolutionary movement at the end of 1874. After that, the movement in Bulgaria started being influenced by the ideas of Hristo Botev who rejected Karavelov's proposals to move BRCC in Serbia, and began to propagate radical views for the liberation and the future of Bulgaria. Like Levski, Botev believed that the liberation, despite its 
dependence on the complicated and tangled Eastern Question, tay only on the broad shoulders of our considerable number of people." Against the rising Balkan nationalism, Botev called for a federation of the Balkans. He believed that the Balkan peoples were able to make social progress only if they were united as one, and all their activities to be headed to a united historical purpose."31

Botev`s worldview represented a further development of the basic ideas of the Bulgarian revolutionary movement created by Rakovski, Karavelov, and primarily by Levski. Botev, however, made a concession in his understanding of some basic principles of Levski, mainly about the preparaion of the revolution. For this reason, Botev did not pay necessary attention to the preliminary preparation of the national uprising. Uprisings during 1875 failed due to unpreparedness and betrayal.

The defeat of the uprisings did not destroy the revolutionary mood of the Bulgarians. N. Obretenov wrote to his mother, Anyway, we will not leave Turkey in peace. To die or to liberate Bulgaria." Stefan Stambolov, the foremost revolutionary leader after the withdrawal of Botev from BRCC, created a new revolutionary center that decided to prepare for a nationalwide uprising in the spring of 1876 .

Co-organized by BRCC located in Romania and revolutionary committees in Bulgaria, the April Uprising began before the appointed date, May 1, 1876, because the leaders of the Uprising might be arrested as a result of betrayal. It attained its broadest scope in southern Bulgaria with the cities of Panagyurishte and Koprivshtitsa. Due to the poor arms, units of the rebels were suppressed by the regular Ottoman Army and irregular bashi-bazouk ${ }^{32}$. This bloodshed, the Bulgarian 
Horrors", aroused international reaction.

April Uprising was suppressed with barbarous cruelty. The Turkish atrocities shocked humanists and democrats of Europe. Eyewtiness account of J. A. MacGahan on Turkish atrocities in Bulgaria, in a letter to the London Daily News of August 22, 1876:

But let me tell you what we saw at Batak ... The number of children killed in these massacres is something enormous. They were often spitted on bayonets, and we have several stories from eye-witnesses who saw the little babes carried about the streets, both here and at Olluk-Kni, on the points of bayonets. The reason is simple. When a Mohammedan has killed a certain number of infidels he is sure of Paradise, no matter what his sins may be ... It was a heap of skulls, intermingled with bones from all parts of the human body, skeletons nearly entire and rotting, clothing, human hair and putrid flesh lying there in one foul heap, around which the grass was growing luxuriantly. It emitted a sickening odor, like that of a dead horse, and it was here that the dogs had been seeking a hasty repast when our untimely approach interrupted them ... The ground is covered here with skeletons, to which are clinging articles of clothing and bits of putrid flesh. The air was heavy, with a faint, sickening odor, which grows stronger as we advance. It is beginning to be horrible. ${ }^{33}$

In contemporary historical science there are two points of view about the role of other social groups in the Uprising. Some historians, such as A. Burmov, Kh. Gandev, and D. Kosev, regard the April uprising as the culmination of a peasant movement whose leadership was in the hands of the intelligentsia. Others, such as S. A. Nikitin and N. Todorov, see the moving forces of the April uprising as the peasantry and the artisans, with the leadership in the hands of representatives of the petite and middle bourgeoisie and the intelligentsia. The debate on this issue reflects the lack of uniformity and coordination among the revolutionary leaders and the participants, thus a strong leadership and organized preparation became extravagant hopes.

In spite of the defeat, the April Uprising shook the Turkish feudal domination in Bulgaria. Importantly, the savage way of the Uprising being suppressed sharply 
increased tensions in international relations and served as one of the causes for the Russo-Turkish War of 1877-78. In general, the failure of the April Uprising could find reason in the betrayal, weakness and disorganization of the Bulgarian bourgeoisie. It was devoid of serious contacts with the foreign world which at the decisive moment might mobilize international support in favor of the Bulgarian cause $^{34}$

The Uprising and its bloody failure caused irreparable moral blow to the Ottoman rule in Bulgaria. It was a shameful stain for Europe. In Britain, where the government of Lord Beaconsfield (Benjamin Disraeli) continued to defend Turkey, the protests were rising. This moral revolution" shocked the bottom of the national psyche, helping Bulgarian society to be liberated from slavery opiates and slave reliance. The Uprising provoked the first international campaign in defense of the Bulgarian nation, in which the greatest minds of the 19th century attended. This movement forced European diplomacy to re-engage with the Eastern Question in consideration of the immediate settlement of Bulgarian liberation. It united the hands of Russia with Bulgaria for immediate military action against the Ottoman Empire. The entire chain of events from 1876 to 1878 started with the April Uprising and ultimately led to the liberation of Bulgaria.

Along with the positive changes, the April Uprising also affected dramatically on the national soul, the social psyche, as well as the Bulgarians' mentality. The Bulgarian bourgeoisie, who could not lead the revolution to its successful end, feared that the Bulgarians would not be able to control their own destiny, and then resorted 
to external strengths. Some national elites attached the destiny of Bulgaria to Russia, others to Austria. The struggle between phile" and phobia" caused more national disasters in the ensuing history of Bulgaria.

\subsection{Liberation of Bulgaria - furitless effort to control own destiny}

After the failure of April Uprising, the liberation movement in Bulgaria fell into severe political crisis. Soon after that, however, stimulated by the shift of the international situation in favor of Bulgaria (the intensifying conflict between the Great Powers, the outbreak of Serbian-Turkish War, the international support for the Bulgarian cause and intensive diplomatic activities in Constantinople), the Bulgarian leaders again took up with revolutionary activities.

Two trends, revolutionary and conservative, were highlighted in Bulgaria and abroad. The revolutionaries began to stand in advantage after the failure of the Uprising.

During the Russo-Turkish War 1877-1878, national movement was developing vigorously in Bulgaria, which was noted in several ways: direct participation of Bulgarians in the Russian army's military actions, eradication of archaic agricultural system in rural areas, destruction of the Turkish farms and spontaneous national movement for the unification of Bulgaria.

The Bulgarians began to prepare for the war at the end of 1876, when Bulgarian

Central Charity Community ${ }^{35}$ asked the Russian authorities to cooperate with 
Bulgarian troops and participate in military operations as an independent fighting unit. This idea was adopted by Russian commanders and supported by Slavic committees. On October 20, 1876, Russian Minister of Defence signed an order for establishing the Bulgarian Army. After the declaration of the War, Bulgarian troops were reorganized under the name of Bulgarian Volunteer Corps, commanded by General N. G. Stoletov. Although Russian commanders determined the supplies and gear of the army, Bulgarian volunteers participated bravely in the battles. Along with the militia, Bulgarians actively participated in the War by a number of other armed formations.

Impelled by the desire of a united Bulgarian state, through the year of 1877 and 1878, a huge movement for national unification was growing in Bulgarian lands. Thus, during the War the powerful national liberation movement came to the end, and merged with the victorious advance of the Russian army who contributed to the liberation of the nation.

In early 1878 , the Russian army achieved victory in the war with the Turks with the enthusiastic help of the newly-established Bulgarian troop opulchenie ${ }^{36}$. By January 4, 1878, when the Russians reached Sofia, the Turks appealed to Britain for mediation. Obstructed by Britain, Russia made treaty at San Stefano with the Turks. The Treaty of San Stefano created the so-called Greater Bulgaria, whose boundaries covered a vast land by the Danube in the north, the Black Sea in the east and the Aegean in the south, and Lake Ohrid and beyond in the west ${ }^{37}$. Although Salonika ${ }^{38}$ was reserved for the Greeks, the treaty maximally satisfied the desires of even the most ardent Bulgarian nationalists, who desired to restore" their dream of the San 
Stefano Bulgaria in the succeeding years. In the meantime, the new Bulgarian State was to be autonomous, to have its own prince and a national militia. As additional conditions, a Russian commission was to be appointed to supervise the new government for two years, and for the same period, a Russia army of occupation was to remain in the state. On the surface, Bulgaria was given an unprecedented territory, but in fact, Russia was to have actual control over the San Stefano Bulgaria ${ }^{39}$.

The Treaty of San Stefano was rejected by the Great Powers. As Stavrianos depicted in his book, it is clear that from the diplomatic viewpoint the San Stefano Treaty was bound to arouse opposition in all quarters. Austria complained with justification that the new Bulgarian principality violated the stipulation in the Budapest Treaty that no large Balkan state was to be established"40. The Powers did not like to see a large country in the Balkans; it would become a barrier to their influence in the southeast Europe.

Soon after March 3, the European Congress prepared for another meeting for the final settlement of the Eastern Question. It ended with the signature of the London Agreement in May 1878.

This preliminary agreement blurred the meaning of the Treaty of San Stefano. Therefore, the London Agreement was adopted as the basis of the Berlin Congress in July 1878. The Great European Powers were present at the Congress - Germany, Austria-Hungary, France, Britain, Italy and Russia, and a Turkish delegation attended as well. The most important task of the Congress was to decide the destiny of the Principality of Bulgaria established in the Treaty of San Stefano, but ironically, 
Bulgarian itself was excluded from participation in the talks.

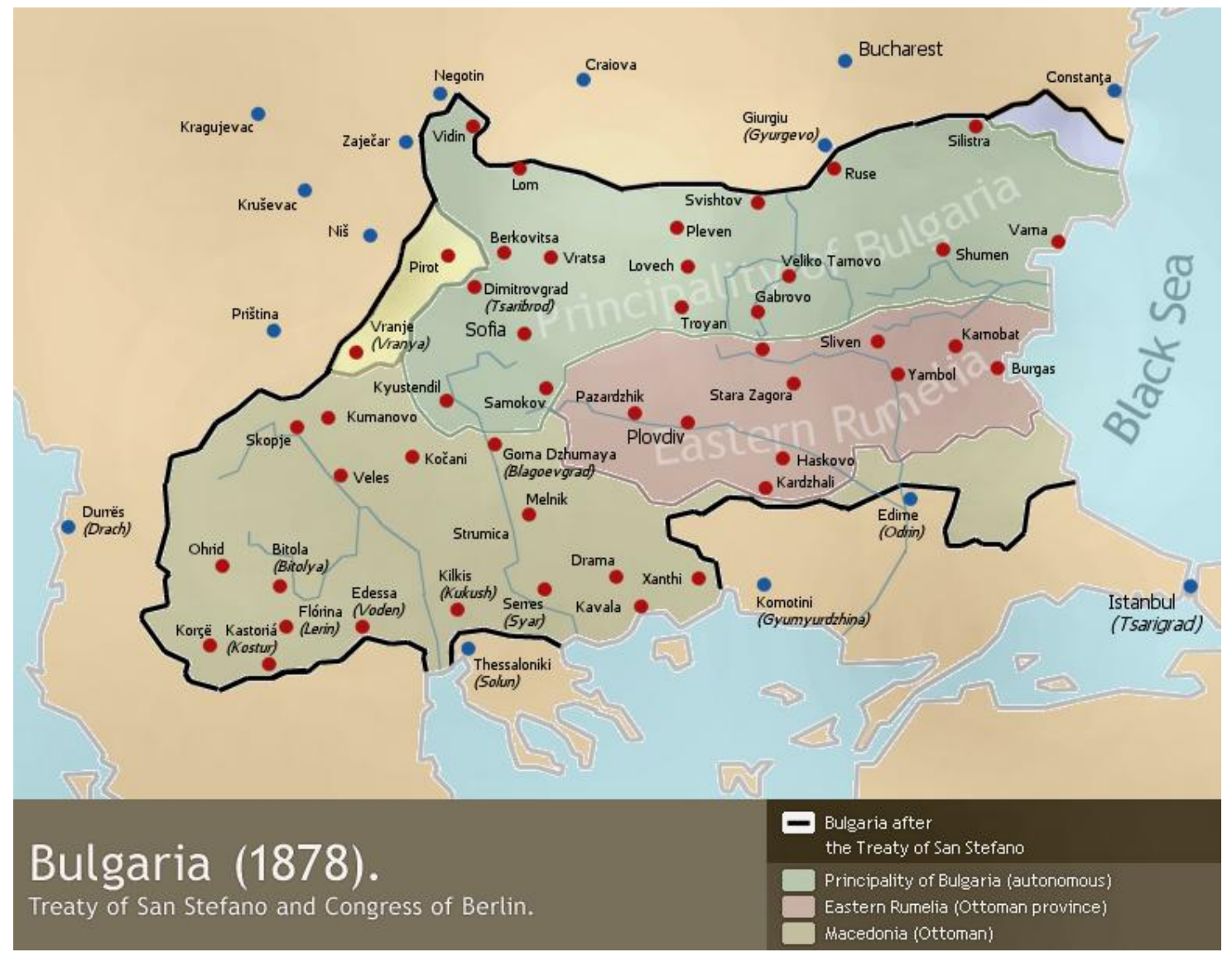

Figure 2-1 Bulgaria in Treaty of San Stefano and Congress of Berlin 1878

(Source: Todor Bozhinov (2008), released under GFDL available on http://en.wikipedia.org/wiki/File:Bulgaria-SanStefano_-(1878)-byTodorBozhinov.png)

Forced by the united opposition of Austria and Britain, Russia acceded to dismember at the Congress of Berlin in 1878. The Macedonian lands were given back to the Ottomans, and this removed Russia's obstacle to southward Austrian expansion. As a result, Bulgaria was deprived of access to the Aegean Sea, which was in the interest of Britain. The remaining Bulgarian territories were divided into two parts, Bulgaria and Eastern Rumelia. Bulgaria, being an autonomous principality, was to be ruled by a prince elected by the Bulgarians, but still under Russian advisory commission and military occupation for nine months. 
The Treaty of Berlin was an act of unfair political relations dictated by the Great Powers at the expense of small nations, which represented the mainstream European and even global phenomena in the $19^{\text {th }}$ century. It had crucial implication for the development of the southeastern European and international relations. Its decrees, inconsistent with neither the principle of nationality nor the natural history and ethnic rights of the Balkan nations, defined the future development of the Balkans by continuous wars and conflicts. It was a detriment of the Balkan nations' interests, as well as preserved the possibility of Great Powers to interfere in the southeast European issues. From a historical point of view, the Treaty was not beneficial to Europe as a whole because it short-sightedly ignored the Balkans' legitimate rights for development and the Balkans was an important part of Europe. Meanwhile, the partition of the Ottoman legacy in the Balkans made by the Great Powers -ereated an era of national egoism in the Balkans."

The other Balkan countries' ${ }^{6}$ independences were recognized and protected by the Powers, but they were also dissatisfied with their territorial loss. Romania lost Bessarabia, which stuck in its throat; the Serbs were upset with Russia ... [who] was consenting to the cession of Bosnia to Austria" ${ }^{42}$. The Bulgarians were most disappointed. Bulgarian scholars believed that the Great Bulgaria preliminarily established in the Treaty of San Stefano was reasonable because eighty percent of the residents living in Macedonia and Eastern Thrace were Bulgarians. Therefore, Freaty of San Stefano accorded with the Bulgarian national culture and historical rights, and also met the common moral and political fairness."43 The Treaty of Berlin 
destroyed the fairness". Some scholars have pointed out that The Treaty of Berlin produced a series of national problems for Macedonian, Bulgarian and other Balkan peoples. Moreover, the Treaty also fueled other controversial problems of long standing and made them more acute." 44 Driven by the dream of restoring the territory of the San Stefano Bulgaria, the Bulgarian politicians and chauvinists led their nation to war-disasters.

Liberation of Bulgaria in 1878, as the result of the Russo-Turkish War, restored the Bulgarian state although in a limited perimeter. However, Bulgaria was still far away from achieving the settlement of the Bulgarian question. Above all, its lands were fragmented under the rule of the four neighboring Balkan countries. Besides, the unfortunate decision of the Bulgarian question was not consistent with the achievements of the Bulgarian Revival in the political sphere. Instead of creating a democratic republic, Bulgaria was turned into a vassal principality, a toy in the hands of the Great Powers. Therefore, it was not an exaggeration to say that in 1878 , the Powers extinguished the results of a century-long development of Bulgaria in Berlin Rathaus. The next mission of Bulgaria would unavoidably be to keep its name, to restore the lost lands, and to provide for its people economic and spiritual progress, without damaging the historical rights of other Balkan peoples.

\subsection{Discussion}

As Wendt elaborated in his constructivist theory, the constructivist strategy treats identities and interests as endogenous to interaction and thus a dependent variable in 
process. Structural change occurs when actors redefine who they are and what they want $^{45}$.

The Bulgarians were the last Christian people of the Balkan Peninsula to attain their liberation. The continuation of the village system in which the peasants were allowed to handle their own affairs almost erased the Bulgarians from the consciousness of Europe that concerned the Greeks, Serbs and Romanians.

Prior to the Crimean War, Bulgarian national liberation movement evolved mainly in peaceful, cultural areas, and armed struggles for political liberation were spontaneous. They occurred as spontaneous acts of self-defense or actions caused by foreign interference. Deprived of political ideology, united leading conception and well-trained leader, these movements were doomed to failure. This period coincided with Bulgarian bourgeois time, in which the unique Bulgarian national culture was created. Meanwhile, the needs of Bulgarian society - to be liberated from the Ottoman oppressors, urged the Bulgarians to define their national identity. Sumner highlighted four midwiferies in the course of the painful birth of a new nationality: The new Bulgaria was being fashioned by four conjoined means: an intellectual and cultural rebirth, Russian assistance, the struggle for a national church, and revolutionary conspiracies." 46

In this course, the Bulgarian national activists identified with the ideals of the Orthodox faith, Slavic origin and language, believing them to be the true and only determinants of their nationality. With the help of these heterogeneous properties in Turkish sense, they draw a demarcation line with the Turks who designed on 
Turkizing the conquered Balkans. As Firkatian pointed out, - Teir nationalists transformed the idea of equality, in the French Revolutionary sense, to mean freedom of oppression from alien elements (ethnic as well as religious) and made it their own." ${ }^{47}$ They also bonded with the neighboring Balkan populations and formed a relationship based on shared beliefs and particularly, experiences of being dominated by their common -enemy" Other. Although there were conflicts of interest between them, the conflicts were always put aside, making way for the principle contradiction as long as the common -enemy" still existed.

Meanwhile, the Bulgarian national figures saw Russia as a big brother" because of common faith, culture and language with Balkan Slavs. They accepted education in Russia, absorbed Russian romantic revolutionary ideas and applied them in the domestic cause. Importantly, the successive years of Russo-Turkish wars introduced a ray of hope to the Bulgarians. Russia actively recruited Balkan Christians in its campaigns against the Ottomans. These efforts aided the awakening" process among the Bulgarians ${ }^{48}$.

By identifying the Ottomans as the enemy Other and the Russians and other Balkan Slavs as the friend-Others, the Bulgarians initially constructed their national identity, defining who they were and what they wanted. Thus, the leaders of national revolutions confirmed their political claims according to the national interests influenced by this identification. They participated in the liberation movements of other Balkan peoples, and attempted to force the Ottoman Porte to enact further reforms while initiating secret negotiation among the Balkan nations, especially the 
Serbs, for the creation of a Balkan federation ${ }^{49}$.

After the Crimean War, the revival process in Bulgarian lands was widening rapidly. The new-formed Bulgarian nation expressed its historical claims, creating political ideas in the resistance against the Ottoman rule. Many national revolutionaries maintained the union of Balkan Christians because of the weakness of the strength of their own people. Moreover, due to the common fate that linked the Balkan peoples for centuries, Bulgarian national activists participated in Serbian and Greek uprising. For them, all nations and countries against Turkey were friends of Bulgaria. Another reason why Bulgarian nationalists preferred alliance of the Balkans was that Bulgaria's self-armed action was still impossible in this period. Each of Bulgaria's neighbors, however, had made substantial gains toward the realization of their respective national goals and saw in Bulgaria only a rival in their territorial and other aspirations. Bulgarian nationalists were viewed for the most part as convenient tools in the common cause to overthrow the Ottoman hegemony over the Peninsula. The Bulgarians found it difficult to unite on the issue of national liberation. Throughout the early nineteenth century, Bulgarian individuals participated in foreign liberation uprisings initiated by their neighbors, but no group or movement supported by a significant number of its compatriots ${ }^{50}$ emerged.

Baffled by Balkan nationalisms, the structure of the Bulgarian national identification began to change. The political idea of the Bulgarian liberation movement turned to independent revolutionary action instead of confederation of the Balkan countries. Thus, the role identities of the friends in the Balkans were changed 
into rivals, with whom the Bulgarian nationalists competed for the support of the Great Powers.

The failure of the April Uprising heavily hurted and even left the Bulgarians without hope to liberate the nation with their own strength. To achieve national liberation, Bulgaria always needed strong patrons. With this in mind, Bulgarians participated actively in the military actions of the Russian army in the course of Russo-Turkish War 1877-1878.

The Russo-Turkish War and its aftermaths were of particular significance for the evolution of Bulgarian nationalism. Firstly, merged with the victorious advance of the Russian army, the national liberation movement achieved its ends. Secondly, the Treaty of San Stefano satisfied the the Bulgarians' request for lands, by which the myth of Bulgarian nationalism began to crystallise. Last but not least, the Treaty of Berlin killed the national myth in its cradle, leading indirectly to national catastrophes in the history of Bulgaria.

As a result of the Russo-Turkish War 1877-1878, the national autonomy brought to the Bulgarians immeasurable joy, as well as discontent with Russia due to the lost territories and Russia's actural control over Bulgaria ${ }^{51}$ according to the Treaty of Berlin. Consequently, the Bulgarian national activists more often turned to other Great Powers for restraining the influence of Russia upon their state. Keeping distance with Russia changed the structure again - Russia was no longer identified as a constantly reliable brother" and protector" of Bulgaria; rather, it became a suspicious and even dangerous manipulator, who was to be a potential enemy of the 
Bulgarian nation.

Due to the limitation of political condition in Bulgarian lands under the Ottoman domination, the Bulgarian national liberation movement lacked a strong leadership with continuity of policy. The ideology and structure of the revolution were changed by the efforts of individual national figure. From Rakovski to Karavelov, to Levski., their ideologies were brilliant in conception but failed because of short-lived revolutionary organization and inadequate preparation for actions. In addition, the major revolutionaries were emigrants who had insufficient understanding and personal contact with Bulgarian local life, which reduced their opportunities to feel intuitively the real demands of the people, weakening their abilities to grasp revolutionary initiative. Furthermore, even though their ideologies all embodied the revolutionary new trends of thought influencing the European continent in the 19th century, they were often at odds with each other about the means by which to achieve the national ends. The various choices made by individual figures determined the trend of revolution, which always had either hopes or dangers for a nation.

\footnotetext{
${ }^{1}$ In this chapter, I use secondary sources for special aspects of the history of Bulgaria. The central texts in my documentation of the key events are: Georgieva, Tsvetana \& Genchev, Nikolai. (2006) History of Bulgaria XV-XIX, Sofia: Anubis; Bodjilov, I. (1993) History of Bulgaria, Sofia: Hristo Botev; Crampton, R. J. (2005) A Concise History of Bulgaria, Cambridge: Cambridge University Press.

2 Alexander Wendt: Social Theory of International Politics, Cambridge University Press, 1999, p. 247.

3 Samuel M. Makinda: Reading and Writing International Relations, Australian Journal of International Affairs, Vol. 54, No. 3, 2000, p. 389-401.

${ }^{4}$ Dale C. Copeland: The Constructivist Challenge to Structural Realism, International Security, Vol. 25, No. 2, Fall 2000, p. 187-212.

5 Yucel Bozdagloglu: Constructivism and Identity Formation: An Interactive Approach, Review of International Law and Politics, Vol. 3. No. 11, 2007, p. 121-144.
} 
${ }^{6}$ Gerry C. Alons: Predicting a State's Foreign Policy: State Preferences between Domestic and International Constraints, Foreign Policy Analysis, Vol. 3, No. 3, 2007, p. 211-232.

${ }^{7}$ Ernest Gellner: Nations and Nationalism, Ithaca: Cornell University Press, p. 49.

${ }^{8}$ Mari A. Firkatian: The Forest Traveler: Georgi Stoikov Rakovski and Bulgarian Nationalism. New York: Peter Lang, 1996, p. 4.

${ }^{9}$ Bulgarian National Revival was part of the European process, making the transition from the Middle Ages to the bourgeois world. It was a later manifestation of the process.

${ }^{10}$ Tsvetana Georgieva, Nikolai Genchev: History of Bulgaria XV-XIX, Sofia: Anubis, 2006, p.300.

${ }^{11}$ Social structure of the Bulgarian cities at the end of the Ottoman rule can be recovered accurately through the official census data, published in the so-called sal nameta. These documents primarily show that number of urban population were increasing, especially the population in major cities like Sofia, Plovdiv and etc, which was a proof of the gentrification of the Bulgarian society, as well as the dominating role of the bourgeoisie in the society.

${ }^{12}$ Georgieva \& Genchev: History of Bulgaria XV-XIX, , 2006, p. 347.

${ }^{13}$ Hilendarski, Paisii: Slavonic-Bulgarian History, Sofia: Damyan Yakov, 2006, p. 41-44.

${ }^{14}$ Georgieva, Tsvetana \& Genchev, Nikolai: History of Bulgaria XV-XIX, 2006, p. 459.

15 Kardjalii were robbers who occurred normally in groups in the Ottoman Empire in the late $18^{\text {th }}$ century and early $19^{\text {th }}$ century because of feudal strife in the Empire.

${ }^{16}$ The Treaty of Kuchuk Kainarji was a peace treaty signed on 21 July 1774, in today's Kaynardzha, Bulgaria. Following the recent Ottoman defeat at the Battle of Kozludzha, the document ended the Russo-Turkish War of 1768-1774 and marked a defeat of the Ottomans in their struggle against Russia. Russia returned Wallachia and Moldavia to the Ottoman Empire, but was given the right to protect Christians in the Ottoman Empire, and to intervene in Wallachia and Moldavia in case of Ottoman misrule.

${ }^{17}$ About the nature of theTreaty of Kuchuk Kainarji and whether it provided Russia a right to act as protector of Ottoman Christians, refer to "Russian Skill and Turkish Imbecility": The Treaty of Kuchuk Kainardji Reconsidered by Roderric H. Davison published in Slavic Review, Vol. 35, No.3 (Sep., 1976), pp. 463-483.

${ }^{18}$ The Treaty of Jassy, signed at Jassy in Moldavia, signed on 9 January 1792, was a pact between the Russian and Ottoman Empires ending the Russo-Turkish War of 1787-92 and confirming Russia's increasing dominance in the Black Sea. The treaty recognized Russia's 1783 annexation of the Crimean Khanate and transferred Yedisan to Russia making the Dniester the Russo-Turkish frontier in Europe。

${ }^{19}$ See A History of Russia by Riasanovsky, part IV, xxv The Reign of Alexander I, 1801-25, pp. 300-323.

${ }^{20}$ Saint Sofronii Vrachanski (or Sophronius of Vratsa; Bulgarian: Софроний Врачански) (1739-1813) was a Bulgarian cleric and one of the leading figures of the early Bulgarian National Revival.

${ }^{21}$ George Petrovich, known as Kara George (1768-1817), founded modern Serbia as the elected leader of the First Serbian Uprising (part of the Serbian Revolution) that aimed at liberating Serbia from the Ottoman Empire (1804-1813); he personally led armies against the Ottomans in several battles, which resulted in a short-lived state which he would administer as Grand Leader from 14 February 1804 to 21 September 1813, simulating a wholly functional state government in war-time. ${ }^{22}$ A protocol of Vidin District Council on August 18, 1850 will be cited in Chapter IV, showing the miserable living conditions of Bulgarians under the Ottoman rule.

${ }^{23}$ M. Arnaudov, ed.: Archive of G. S. Rakovski. Letters and Manuscripts of Rakovski I, Sofia: BAN, p. 79-81.

${ }^{24}$ The Committee was called later Bulgarian Central Trusteeship".

${ }^{25}$ Rakovski organized the First Bulgarian Legion in Belgrade in 1861-1862, but it ended in failure due to the unsuccessful interaction with the Serbian government.

26 This doctrine advocated to establish an Orthodox unity under the leadership of Russia.

${ }^{27}$ Karavelov demonstrated the ideas in his newspaper Liberty. For detailed citations please see Chapter IV.

${ }_{28}$ Georgieva \& Genchev: History of Bulgaria XV-XIX, , 2006, p. 509.

29 Nikolai Genchev: Vasil Levski, Sofia: Military Press, 1987, p. 232

${ }^{30}$ About Levski's notions on the future democratic Bulgarian country, refer to Vasil Levski. Traces of 
his Life by Stojanov.

${ }^{31}$ Flag, December 22, 1874.

${ }^{32}$ Turkish word, means leaderless and disorderly. Bashi-bazouk represented irregular soldier of the Ottoman army, noted for lack of discipline.

33 London Daily News, August 22, 1876.

${ }^{34}$ Georgieva \& Genchev: History of Bulgaria XV-XIX, , 2006, p. 538.

35 An organization established in July, 1876, the head of which was sent from Moscow Slavophiles. Its policy was focused on foreign military occupation of Turkey instead of nationwide revolution of Bulgaria.

${ }^{36}$ Опълчение in Bulgarian, means militia.

${ }^{37}$ See ART. VI of the Preliminary Treaty of Peace, signed at San Stefano in The European Concert in the Eastern Question 335-348, Holland.

${ }^{38}$ Now the city is known as Thessalonica, the second-largest city in Greece. In 1235, Bulgarian Tsar Ivan Asen II vanquished Epirus, and therefore the city became the vassal territory of Bulgaria. After the death of Tsar Ivan Asen II, Bulgarian state weakened and in 1246, the city was annexed in the Empire of Nicaea. In this city were born Saints Cyril and Methodius, two brothers who devised the Glagolitic alphabet, used by Bulgarians and majority Slavs. Mainly for this reason, the Bulgarians admired to regain Salonika to achieve a kind of national dream.

${ }^{39}$ ART.VIII of the Treaty stipulated: The Ottoman army will no longer remain in Bulgaria; the strength of the Russian army of occupation to be composed of six divisions of infantry and two of cavalry, which will remain in Bulgaria after the withdrawal from Turkey by the Imperial army, shall not exceed 50,000 men.

ART.XI - The Mussulman proprietors or others who fix their personal residence outside the Principality may retain their estates by having them farmed or administered by others.

Turko-Bulgarian Commissions shall sit in the principal centers of population, under the superintendence of Russian Commissioners, to decide absolutely in the course of two years all questions relative to the verification of real property, in which either Mussulmans or others may be interested.

ART.XXV - Within three months after the conclusion of the definitive peace between His Majesty the Emperor of Russia and His Majesty the Sultan, the Russian army will withdraw completely from European territories of Turkey, with the exception of Bulgaria.

40 L. S. Stavrianos: The Balkans since 1453, New York University Press, 2000, p. 409.

${ }^{41}$ Refer to History of Yugoslavia by Vladimir Dedijer, Ivan Bozic, Sima Cirkovic, Milorad Eumecic, pp. 456.

Luigi Albertini's words in his work The Origins of the War of 1914, Volume I, Oxford University Press, pp.32.

${ }^{43}$ I. Bodjilov et al.: History of Bulgaria, Sofia: Hristo Botev, 1993, p. 403-404.

44 Sava Penkov: Treaty of Berlin and the Balkans. Sofia, 1985, p. 6.

45 Alexander Wendt: Social Theory of International Politics, Cambridge University Press, 1999, p. 336.

${ }^{46}$ B. H. Sumner: Russia and the Balkans 1870-1880. Hamden, London: Archon, 1962, p. 108

${ }^{47}$ Firkatian: The Forest Traveler: Georgi Stoikov Rakovski and Bulgarian Nationalism, 1996, p. 3.

${ }^{48}$ Ibid, p. 7.

49 D. K. Kosev: Russia, France and Bulgarian Liberation Movement 1860-1869, Sofia: BAN, 1978, p. 5 .

${ }^{50}$ Firkatian: The Forest Traveler: Georgi Stoikov Rakovski and Bulgarian Nationalism, 1996, p. 11.

${ }^{51}$ Evidence for this discontent will be found in Chapter IV, in which the public response to the Treaty of Berlin is to be interpreted. 


\section{CHAPTER 2 RUSSIA AND BULGARIAN}

\section{NATIONALISM ${ }^{1}$}

-fl Russia comes to liberate, she will be received with great sympathy; but if she comes to rule, she will find many enemies," wrote Lyuben Karavelov, one of the most distinguished Bulgarian writers and an important figure of the Bulgarian National Revival. His words expressed the ambivalence of the Bulgarians and even the Balkans as a whole towards the Russia's liberating them from the Ottoman domination and its control over the Balkans, especially the Balkan Slavs. In the previous chapter, I have set the historical context for the emergence and the rise of Bulgarian nationalism in general, examing how the national identity of the Bulgarians was learned. This chapter is dedicated to digging out the Russian elements in the development of Bulgarian nationalism, reviewing the remarkable historical moments in the diplomatic interaction between Russia and Bulgaria.

On the basis of Russian national interest and power politics, as the historians asserted, the chief goal in the Balkan Peninsula was to control the key" to Russia's back door, namely the Straits and Constantinople. Despite all the turns of Russian policy in the $19^{\text {th }}$ century, this objective remained constant. In Russian foreign relations, all Balkan interests were subordinated to the problem of the Straits ${ }^{2}$. Only actual control over the Strait could offer Russia the passport of navigating warm 
waters.

Geographically, the Balkan Peninsula, standing on the choke point between Asia and Europe, was known as a crossroads of East and West. It has been a juncture between the Latin and Greek bodies of the Roman Empire, the destination of a massive flowing of Slavs, an area where Orthodox and Catholic met, as well as the meeting point between Islam and Christianity. It is an area lying in southeastern Europe surrounded by water on three sides: the Adriatic Sea to the west, the Mediterranean Sea (including the Ionian and Aegean seas) and the Marmara Sea to the south and the Black Sea to the east. The Danube, Sava and Kupa rivers are generally accepted as the physical northern boundary of the peninsula, but the concept The Balkans" may also include Slovenia and Romania (See figure 2-1). As the northern barrier, the Danube is not so effective to defend against the intrusion of external forces. Wesley Gewehr argued, If the Balkan peninsula had been protected by a mountain barrier such as the Pyrenees or Alps, in all likelihood the development of nationalism there would have been less interrupted by outside intervention."3 


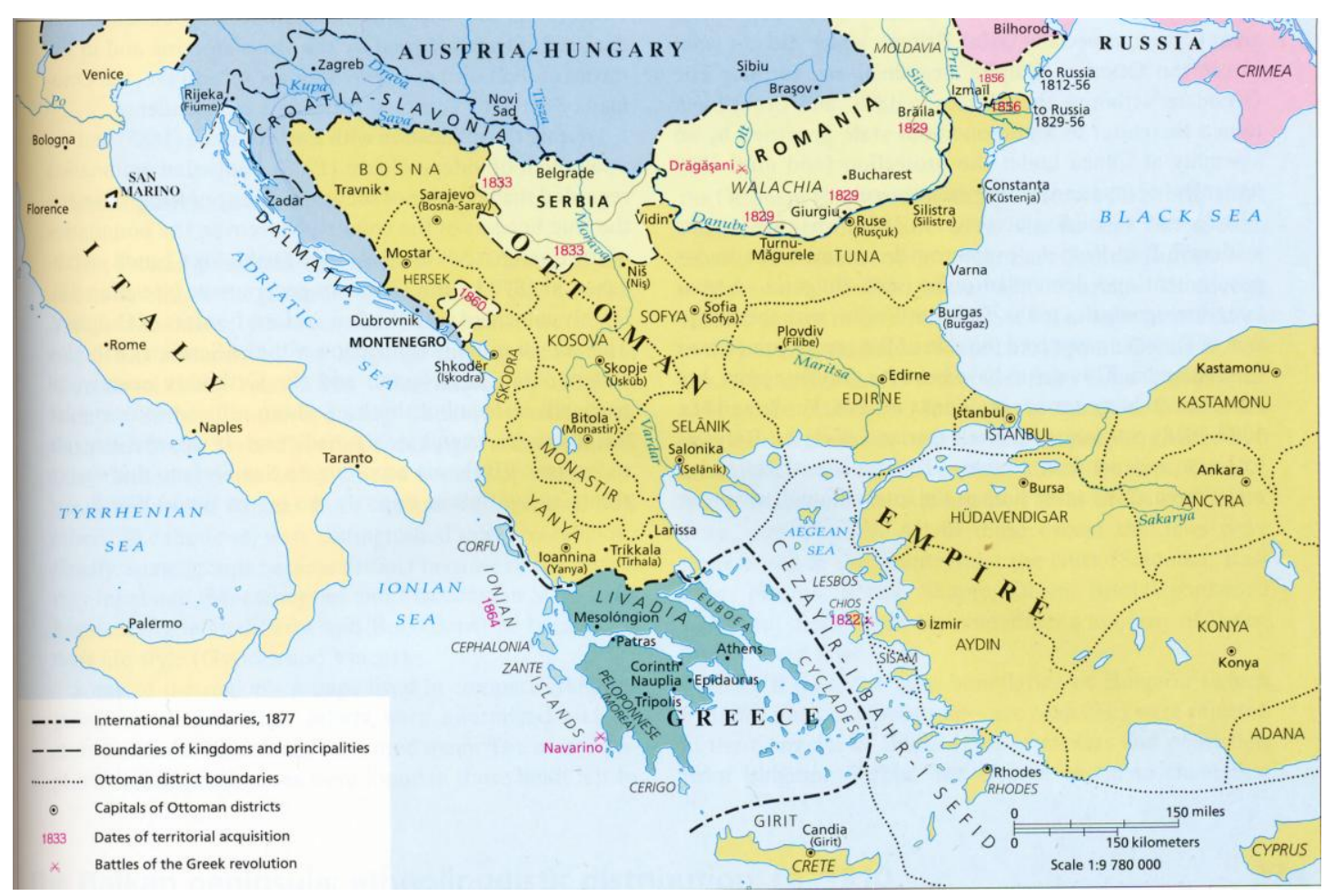

Figure 2-1 The Balkan peninsula 1817-1877

(Source: Paul Robert Magocsi (2002): Historical Atlas of Central Europe, available on http://cosmos.ucc.ie/cs1064/jabowen/IPSC/php/cs.php?byauid=46074)

The importance of the Balkans attracted Russia in many ways. The four Russian tsars - Alexander I, Nicholas I, Alexander II and Alexander III - and their most influential foreign ministers often considered their state as part of the European system, holding firmly to the principle of equilibrium, namely the balance of power in international relationships ${ }^{4}$. Driven by the principle, prior to the Crimean War, Russian policy had been supportive to all the Orthodox peoples of the Balkans against both the Turks and the Austrians. Meanwhile, to answer the more ambitious initiatives of Britain, France, the Ottoman Empire and the Hapsburg Empire globally, from the $18^{\text {th }}$ century to the outbreak of WWI, the Russian government remained continuously involved in the affairs of the Balkan peninsula. It sought exclusive domination in Constantinople ${ }^{5}$ and it was willing to make sacrifices often disproportionate to the issues at stake ${ }^{6}$. This is not a point that this project will be 
concerned with; rather, the project will concentrate on the ideological aspect and the unique national and cultural relationship between Russia and the Balkans, represented by the Bulgarians.

Romanticism, the French Revolution, as well as the Industrial Revolution together were three impelling forces that made possible and perhaps inevitable the general nationalist process. However, without the aid of propaganda forged chiefly by doctrinaires and used with telling effect upon the masses, the historical process could not have taken the precise shape it took, nor could the present nationalist state of mind, so universal throughout the world, be exactly what it is ${ }^{7}$.

In Russia, as in the West, the shaping of nationalism felt the impact of early Romanticism, in particular the Romantic nationalism articulated by the German thinker Johann Herder. His concept of Volksgeist ${ }^{8}$ maintained that each nation expressed its creative genius in language, art, literature and folklore. Each national culture, springing from its own people, embodied that nation's soul or spirit. National consciousness and Volksgeist laid a foundation for an authentically national modern culture.

Herder also took a special interest in the development of the Slav peoples. He considered the Slavs would be new and tncorrupted" nations destined to a great future, and his writings aroused a strong national consciousness amongst the Slavs of Central and Eastern Europe 9 . Along with Russia‘s victory over Ottoman Empire and the liberating movement of the Balkans from the Ottoman rule, the growth of national consciousness spread throughout the Balkans. The decline of the Ottoman 
Empire offered Russia a possible alternative in dealing with the Ottoman territories, in particular with the Balkans. Russia was the most persistent opponent of Britain, whose status quo policy worked unceasingly to preserve the integrity of the Ottoman Empire. Russia made its interests in the Balkans clear in a note that it circularized at the Vienna Congress in February, 1815. The note stated that the emperor of Russia was the natural protector of the Orthodox Greek Christians under Ottoman domination." 10 In the same manner that Russia was obliged by its religion to go to the aid of the other oppressed Balkan Christians.

The strong link between Russia and the Balkans in terms of common Orthodox faith, similar attitude toward past history, and complex of big and little brothers" constituted the close connection between the nationalism of Russia and the Balkans. Regardless of its ultimate goal, Russia, as a big brother of the Balkan Slavs, encouraged the national movements and supported the division of the peninsula into autonomous or independent states.

From another perspective, Russia's influence upon the Balkans' modernization, to a significant degree, represented the Balkans' intention of turning to the Western ideology, as Cyril Black pointed out, In an important sense, Russia has served as one of the channels through which Western ideas and institutions reached Southeastern Europe. Moreover, within Russia the Western heritage was reinterpreted and adapted to Russian traditions and needs, and this new form was frequently in a position to compete in Southeastern Europe with more direct Western influences." ${ }^{11}$ That is not to say, however, that Russia adopted Western practices in mass and transmitted all of 
them to the Balkans. It is unignorable that the modern values accepted by Russia from Western ideas, along with Russian native ideologies, exerted a significant influence on the modernization of the Balkans. This issue will be elaborated in Chapter Four.

With the support and protection of Tsarist Russia, some Balkan nations regained national independence. Nevertheless, for the fear of the increasing mightiness of Russia and its power and ambition in the Slavonic world, once the national governments were established, the Balkan states did not share a similar feeling of responsibility or attachment to Russia ${ }^{12}$. Expecting external help to curb further expansion of Russia in the region, the new modern Balkan states were willing to look to any power for cooperation and encouragement, including their former rulers, and turned sharply against their former protector and patron. In other words, when Russia played a role of liberator and protector against Ottoman control, Balkan and Russian national myths went hand in hand. The Balkans willingly appealed to and accepted Russian military aid because of the common religious and cultural traditions. When their goal of national liberation had been achieved, the Balkans was no longer willing to be dominated by Russia, either militarily or politically. Just as Lyuben Karavelov said, If Russia intends to subjugate the peoples in the Balkans, then she will multiply her enemies who sooner or later will produce a fatal blow on the dominating tribe." $" 13$

In brief, Russia played a dual role in the formation of Balkan nationalism. On the one hand, Russia helped the Balkan peoples, Slavs and non-Slavs, to achieve national 
independence, an appropriate circumstance for Balkan nationalisms to grow. On the other hand, for fear of Russia's supremacy and the potential ambition of its Pan-Slavism policy, the Balkan nationalism demonstrated Russophobia, and subsequently evolved into a kind of nationalism embraced by underprivileged nations - more radical and more xenophobic, which foreshadowed the intensification of the Balkan ethnic problems.

\subsection{Russia’s political concerns in Bulgarian National Revival14}

Before the war with Turkey in 1877, Russia, due to Slavdom and Orthodox power, had been regarded by the Balkan Slavs (the Serbs, Bulgarians and Montenegrins) as the one country among the great powers that could help them to fulfill their hope of national independence ${ }^{15}$. The Balkan Slavs expected being protected by their powerful northern neighbor against the Ottoman Empire because of racial and religious ties. From another perspective, on the basis of Russian national interest and power politics, the chief goal in the Balkan peninsula was control over the Straits ${ }^{16}$. Đespite all the turns of Russian policy in the nineteenth century, this objective remained constant. In Russian foreign relations all Balkan interests were subordinated to the problem of the Straits." ${ }^{17}$ Taking into account the strategic interests of Russia in the Straits, the tsarist officials were willing to sacrifice some inessential interests of their own state to meet Balkan requests for aid and protection. The strategic importance of the Balkan peninsula was the basic motive that 
stimulated Russia to be involved in Balkan national movements.

Together with military and strategic consideration, the Panslav ideal of the unity of the Slavic, Orthodox people impelled Russia to take actions in the Balkan region. In the regard of Slavdom and Orthodoxy, Russia attracted Bulgaria, Serbia and Montenegro; on the basis of Orthodoxy alone, Romania and Greece came in on its side. For the fear that its interests in the Balkans would be damaged by other powers, Russia exploited its advantage in ideology to gain predominant influence in the Balkans.

With Turkish sultans in Istanbul proving unable to control the vast empire assembled by their ancestors, the Eastern Question ${ }^{18}$ started to be regarded as the most insoluble and dangerous topic of European diplomacy during the $19^{\text {th }}$ century. The main point of the Question is the instability of the region under the rule of the Ottoman Empire in Europe. The intrinsic danger in the Eastern Question is the risk of war between the European powers because each of them nervously tried to ensure that none of the others gain any advantage when Turkey was crumbling. Among the powers, Russia, Turkey's nearest neighbor became the greatest fear for others. The contradictions between the Western powers, the geographical proximity of Russia to the Ottoman provinces, and the support that Russian politics exerted amidst the Christian polulation in the East, indeed offered advantages to Russia than to her competitors $^{19}$.

To create a Russian empire is the dream of the Russians. From the succession of Peter the Great, Russia started its history as a European power. In addition to 
domestic reform, diplomacy became an important means to achieve the goal. Russian foreign policy was chiefly directed toward Europe and relations with the other great powers. The unique geo-strategic position of the Balkan peninsula made it the key of Russian diplomacy to Europe. The basic point of Peter the Great's foreign policy was succeeded by subsequent tsars. Since then, Russia began to approach the Black Sea through wars. The Black Sea, as the main channel in southern Russia, played a vital role in the development and security of Russia as a whole. The first priority in Russian Black Sea strategies was to control the all-important Straits - the Dardanelles which gives access from the Aegean to the Sea of Marmara, and the Bosphorus connecting the Sea of Marmara with the Black Sea. Free access to the Straits that link the Mediterranean Sea to the Black Sea would help Russia to gain access to the Mediterranean, and then southwardly expand its frontier.

In the 200-year-history after Peter the Great, Russia had gradually established a predominant position in Europe, obtaining vast lands around the Black Sea. But due to the intervention of Turkey and other major powers, Russia was not able to occupy the Black Sea Straits in real sense.

Driven by the dream of being a great power, Russia, as a member of the Holy Alliance $^{20}$, had operated as the Policeman of Europe", maintaining balance of power. The weakness of the Ottoman Empire (described by Tsar Nicholas I in 1844 as the sick man of Europe") inspired Russian national honor, and made Russia desire to expand in Europe; in particular, it would be an opportunity for Russia to get an access to the Mediterranean and to occupy the Balkans. Moreover, the presence of 
Christians offered a seemingly dignified pretext to actively involve in Turkish affairs. Prior to 1852 , pressed by Russia, the Turks have granted custody of the Christian churches (the Holy Places) ${ }^{21}$ within the Ottoman empire to Orthodox priests. In response to Napoleon III's demands that the sultan restore Roman Catholic rights in the Holy Places, Russia claimed to protect all Orthodox Christians in the Ottoman empire. This alarmed France and Britain who feared that Russia was trying to re-establish a unique and exclusive influence over Turkey and even in the Balkans. Convinced by the western powers, the Turkish Sudan rejected the claims of Russia, and the Tsar used the rejection as the pretext to march his armies into the Danubian Principalities of Moldavia and Wallachia ${ }^{22}$ in July 1853 . Within a few months after that, the Ottoman Empire, France and Britain formed an alliance, declaring war against Russia. The Crimean War began.

The Treaty of Paris, signed in 1856, settled the Crimean War between Russia and the joint European powers. The resulting treaty removed much of Russia's sway over Turkey, for it lost territory granted to it at the mouth of the Danube and was forced to abandon its claims to protect Christians in the Ottoman Empire. The treaty marked a severe setback to Russian influence in the region.

After the Crimean war, Russia ceased to treat herself as the gendarme of Europe", and did not play a leading role in affairs of Europe for twenty years. The weakness of Austria in 1866 and 1867 and the simultaneous revolt in Crete might have given her the chance of moving forward again in the Balkans; so might the France-Prussian War. Although in 1870 Russia did move forward in the Black Sea, 
she did not feel strong enough to challenge the issue of the Crimean War. Foreign affairs were still secondary, and the major issues lay at home $\mathrm{e}^{23}$.

Besides, with Western ideas of nationality being importing into the Ottoman empire, by 1875 the fermenting effects of new nationalism were felt. Fired by the example of Italy, many of the younger generation among the Balkan Christians thought and felt that nationality disrupts the old empire ${ }^{24}$. Connected with the Turkish administrative domination, the Greek hierarchy represented the foreign cultural rule for the Bulgarian nationalists. The small minority, cultured and better-off class in the Bulgarian society, had been in danger of completely succumbing to Hellenism. They wrote in Greek or at best in Bulgarian with Greek script; the Greeks monopolized the Church posts; in the few schools only Greek was taught. Intensified by the long Greek cultural suppression, it was inevitable that the Bulgarian national regeneration would be founded on opposition to the Greeks as largely as to the Turks. Already a generation earlier, during the $1828-9$ campaign, it was apparent to the Russians that the Bulgars were hostile to the Greek upper clergy, as much as to their oppressors the Turks, and to the Greek suppression of Bulgarian nationalism ${ }^{25}$.

With the crystalizing of the Balkan national aspirations, in Turkey itself Hellenism was being more and more seriously challenged by the painful birth of a new Balkan nationality, owing largely to Russian midwifery ${ }^{26}$. Russia, in virtue of the situation, intended to recover territorial losses it had suffered during the Crimean War and reestablish its influence in the Black Sea and the region as a whole.

Within Bulgaria, some national revolutionaries, represented by Rakovski, 
insisted that the country could achieve national ends only by their own strength; other national elites, nevertheless, believed in taking all they could get from Russia and entirely relied on Russia's salvation. Naiden Gerov, as the First Vice-Consul” of Russia in Plovdiv, strove to further the liberation of Bulgaria from the Ottoman Empire. But differing from those who wanted to obtain liberation through armed uprising, such as Lyuben Karavelov, Vasil Levski, and Hristo Botev, Gerov relied on help from Russia and was opposed to the more radical revolutionary way. $\mathrm{He}$ dreamed of a peaceful, enlightening and diplomatic propaganda advised by the Russian Embassy in Constantinople; and the revolution that he imagined and promoted had but one purpose - provoking the intervention of Europe to arouse her humanity and to legitimize the war launched by Russia ${ }^{27}$.

In the sixties Bulgaria and Serbia intended to act jointly against the Turks, which was to received much encouragement from Russia. Plans for a Bulgarian-Serbia confederation were designed in 1867, but the Russians could not combine the divergent parties of the Bulgarians in Bucarest. In 1867 and 1868, financed by Nikolai Ignatiev, when the Russian ambassador to Constantinople launched two small uprisings ${ }^{28}$ through Naiden Gerov. Although the uprisings only brought drastic reprisals by Midhat Pasha ${ }^{29}$, with no co-operation with Serbs, Gerov spoke highly of them. On August 21 1868, he sent a report to Ignatiev, in which he praised the uprisings as necessary stages in the struggle for national liberation and concluded: From this perspective, the actions in the past years were not fruitless ... now we may think about uprising in the real sense."30 
The Bulgarian exarchate was established in 1870. Undoubtedly, it is the first consequence of Bulgarian nationalism in the struggle of the Bulgarian Orthodox against the domination of the Greek Patriarchate of Constantinople. But even if it may as much be credited as a gain for Russia, the means by which it was brought about and the circumstances attending it did not represent a clear victory either for St. Petersburg or Moscow ${ }^{31}$. The anti-Russian spirit and the desire of Bulgarian nationalists for a really independent church had already been emphasized in Bulgarian press of the time ${ }^{32}$.

As early as in the autumn of 1876, the Russian government announced partial mobilization, engaging in a battle of life and death to return to her status and dignity in Europe prior to the Crimean War. Balkan states, out of their national consideration, were determined to take advantage of the favorable situation formed in the military conflicts and contradictions between Russia and Turkey ${ }^{33}$.

On the other side, the Turkey's misrule stimulated the anti-Turkish sentiment among the Balkans. Hristo Botev wrote enthusiastically: Herzegovina is fighting; Montenegro is spreading over its mountains and coming with help; Serbia is ready to put its forces on the move; Greece is about to declare war; Romania will not remain neutral ... Is there any doubt that death is hanging over Turkey?"34, Botev's overoptimistic words ignited the revolutionary passion of the Bulgarians. The April Uprising broke out in central Bulgaria on May 2, 1876, eleven days earlier than planned because of treachery and arrests. The uprising was finally brutally suppressed by the units composed by the regular Ottoman Army and irregular 
bashi-bazouk. This bloodshed, called Bulgarian Horrors", aroused the international reaction. The April Uprising was a failure as a revolution, but as the Greek-Canadian historian L. S. Stavrianos said, the Bulgarian Horrors' contributed appreciably to the combination of pressures that finally culminated in the intervention of the powers, in the Russo-Turkish War, and finally in the liberation of Bulgaria." 35

The failure of the April Uprising exposed a number of problems - ideological immaturity, the Bulgarian people's lack of practical preparation for a large-scale, long-lasting revolutionalry movement, and the inferiority of their military equipment, etc. Yannis Sygkelos attributed the failure to the weakness of Bulgarian nationalism".

Following the Herzegovina Rebellion that started in 1875 and the Bulgarian April Uprising, the Constantinople Conference was held by the Great Powers from December 1876 until January 1877, in which the Powers agreed on a project for political reforms both in Bosnia and in the Ottoman territories. The Turks nevertheless announced the Ottoman Empire's definitive refusal to accept the conference's decisions $^{36}$. After the failure of the Constantinople Conference, the Eastern Crisis began to move towards war. The Russian diplomacy undertook a favorable international environment for her upcoming military action. On January 15, 1877, Russia signed the so-called Budapest Convention with Austria, according to which Austria would remain benevolently neutral in case of war between Russia and Turkey, and in return Austria could annex Bosnia-Herzigovina.

Meanwhile, Russia made another effort for a peaceful diplomatic circumstance 
in her favor. On March 31, 1877, persuaded by Russia, the Powers signed the London Protocol, in which Turkey was asked to introduce the reforms proposed by herself. The Turks rejected the proposal, and finally, Russia declared war upon Turkey in April the same year.

With the help of the Bulgarian troop Opulchenie, the Russian army won the War. In January 1878, Russia signed treaty at San Stefano with the Turks. Through the Treaty of San Stefano, Russia's century-old dream of expelling the Turks from the Balkans was on the verge of success - grasping the key to the Straits, which was significant for Russian strategy in Europe as it sealed off the Straits area from the European continent ${ }^{37}$

The Treaty of San Stefano satisfied both Russia's Balkan ambition and Bulgaria's territory claims; meanwhile, it jeopardized the interests of almost all countries concerning the region, including not only European powers such as Austria and Britain, but also other Balkan states. Austria complained with justification that the new Bulgarian principality violated the stipulation in the Budapest Treaty that no large Balkan state was to be established; Britain feared that Russia's acquisitions in Asia Minor would eventually culminate in a Russian base on the Gulf of Alexandretta; the Greeks received nothing when the war ended, with Bulgaria becoming the largest state in the Balkans; the Serbs occupied a considerable area of Macedonia while the Turks were fleeing before the Russians, but all this territory was to be incorporated in the Bulgarian principality ${ }^{38}$. In this context, the Treaty of Berlin came into being.

The Treaty of San Stefano was a turning point for both Russia and the Balkans. 
Its unilateral scheme of distributing the Turkish territory in the Balkans intensified the existent contradiction between Balkan states. Although by signing it, Russia had nothing more than aiming at a temporary rough draft to enable a final settlement with other Great Powers, the Bulgarians almost immediately regarded it as the central point of their foreign policy, which lead to the disastrous Second Balkan War and its even more disastrous participation in WWI. In other words, the treaty offered Bulgaria a glorious dream and harsh reality.

In the subsequent Treaty of Berlin of 1878 , Bulgaria was deprived of access to the Aegean Sea, which was in the interest of Britain and a severe loss for Russia. Furthermore, giving the Macedonian lands back to the Ottomans removed Russia's obstacle to southward Austrian expansion. But Russia did end up with something. The remaining Bulgarian territories were divided into two parts, Bulgaria and Eastern Rumelia. Bulgaria, an autonomous principality, was to be ruled by a prince elected by the Bulgarians, but still under Russian advisory commission and military occupation for nine months.

At both San Stefano and Berlin, to defend its interests at the Straits against Bulgaria and salvage as much as possible out of the former treaty, Russia showed its readiness to make her fateful choice of Bulgaria over Serbia. Although in the past, Russian policy had been supportive to all the Orthodox peoples of the Balkans against both the Turks and the Austrians, Russia recognized after the Crimean War that such commitments were too widespread. Of the lands under Turkish control, those inhabited by the Bulgarian people were of principal importance because of their 
strategic position in regard to the Straits ${ }^{39}$.

In the fall of 1871 , when relations between Serbia and Austria cooled because of conflicting ambitions in the Bosnia-Herzegovina, Prince Milan of Serbia visited the Russian emperor to win Russia's support for territorial aspirations of Serbia. But Milan failed to get what he wanted from Russia, largely because Russia, along with Austria, was not willing to support any Serbian ambition that might threaten the status quo in the Balkans, for which the well-known Three Emperors' League concluded in 1872 was a good proof. Subsequently, throughout the Hercegovina Uprising of 1875-1878, Russia also demonstrated her diplomatic priority in the Balkans. The truth was that Serbia, together with Bosnia-Hercegovina was tentative influenced sphere of Austria, whose interests centered there. If Russia had not gained Austrian acquiescence, its strategic plan in Bulgaria would have be prevented. On balance, Russia decided to make a concession to sign the Reichstadt agreement ${ }^{40}$ with Austria, according to which Austria would allow Russia to regain the southern Bessarabian territory that she had lost in Crimean War; Russia, in return would allow Austria to gain Bosnia. Even though the San Stefano Treaty recognized Serbia and Montenegro to be independent, their interests were completely subordinated to those of Bulgaria. The most direct was that, after the signing of the Treaty of San Stefano, the Serbs protested to St. Petersburg because of her dissatisfaction with the territory of Macedonia, but were informed bluntly that Russia's interests came first, Bulgaria's second, and Serbia's last ${ }^{41}$

The most important task of the Congress of Berlin had to do with Bulgaria, on 
the grounds of reconsidering the Treaty of San Stefano. Eventually, the new-established autonomous principality was divided into three parts: Bulgaria proper, north of the Balkan Mountains, to be autonomous with its own elected prince; Eastern Rumelia, south of the Balkan Mountains, to be under a Christian governor appointed by Constantinople but approved by the powers; and Macedonia, which was to remain under direct Turkish administration ${ }^{42}$.

The Congress of Berlin aimed at weakening Russia's influence in the Balkans, as the British Prime Minister Disraeli (1874-1880) made clear from the beginning that the principal object in being sent to Const. is to keep the Russians out of Turkey, not to create an ideal existence for Turkish Xtians" ${ }^{\text {43 }}$. As a result, the Berlin Treaty disregarded ethnic and nationalist considerations of the Balkans, and embittered the Balkan peoples. The Bulgarians long suffered from being partitioned, and since then the entire nation was getting involved in the unification of their country, until in September 1885, the Principality of Bulgaria and the then-Ottoman province of Eastern Rumelia declared their unification. The Serbians were dissatisfied by the advance of Austria into Bosnia-Herzegovina and the Sanjak of Novi Pazar ${ }^{44}$, which set the scene for the Bosnian Crisis of 1908-1909 ${ }^{45}$, and even for World War I.

The Treaty of Berlin achieved the European Powers' goal to weaken Russia's influence in the Balkans. The Powers profited from the partition of the Ottoman legacies in the Balkans, which greatly enhanced the power of Austria", and also ereated an era of national egoism" ${ }^{46}$. For the Balkan peoples, the Berlin Treaty meant not peace with honor but rather frustration of national aspirations and future 
wars in the region ${ }^{47}$

From the Russian perspective, despite the Panslavic ideas, Russia considered the interests of its national strategy above those of a united Slavdom. More importantly, the bankruptcy of the treaty marked the failure of Russia's Balkan diplomacy. From another point of view, Russia's role in the Balkan liberation movements consequently altered from supporter to intervener and destructor. The Balkan leaderships were willing to accept Russian military support, but not Russian political predominance. Accordingly, after obtaining national independence, the Balkan states turned against Russia, as Barbara Jelavich analyzed in her article entitled Tsarist Russia and Balkan National Liberation Movements: a Study in Great-Power Mythology":

After that, Russian officials and advisers stepped on sensitive national toes. When the Russian government failed to give the expected assistance to further national advancement, the Balkan nations turned sharply against their former protector and patron. They showed themselves, in fact, willing to cooperate with any court that would offer them assistance, even when such policies were damaging to Russia. The Balkan states' rivaling political parties tended to look to different powers for support and encouragement 48 .

In the late $19^{\text {th }}$ century, nationalist sentiments continued to ferment in Serbia and Bulgaria, the two neighboring Balkan states liberated from the Ottoman rule. Around the ownership of the Macedonian territories, the two countries disputed continually. The Serbian ruler Milan $^{49}$, a Russophobe, detested the Bulgarian government, which he regarded as a tool of Russian interests. In nature, however, Milan did have much in common with Alexander of Battenberg. Both had been educated in the west and believed that they were representatives of a higher 
civilization than that of the countries they ruled; both distrusted the historic attachment of their nations to Russia and suffered extremely disagreeable experiences in their relations with Russia. What's more, both wished to rule as autocrats rather than constitutional monarchs. Despite so commonality, each of them ambitiously sought precedence over the other. Confronted with the two rulers, it seemed hard for Russia's diplomacy to the Balkans to move forward; even worse, it was difficult for Russia to play the role of an arbiter.

\subsection{Pan-Slavism and Slavic consciousness}

Pan-Slavism, as Hans Kohn defined, was a movement in which nationalist elements were interwoven with supranational and often imperialist threads, and a product of the political awakening of the intellectual in central and eastern Europe ${ }^{50}$. It was brought about by the Pan-Germanism arising during the era of Napoleon's domination of Europe, when minorities, feeling their interests were being sidelined by the Napoleonic Code, began to stress the common links of history, culture and language. This nineteenth-century concept of the unification of all the Slavic people, was allegedly endowed not only with a linguistic fraternity but also with unique cultural values and traditional virtues. The term Pan-Slavism was used for the first time in Bohemia in 1826 and found wider expression during the 1848 Slavic Congress in Prague, where its main proponents were Czech delegates led by F. Palacky. It was also popular among the nations of the future Yugoslavia.

In Russia, classical slavophilism ${ }^{51}$, focusing on the internal spiritual life of 
Russians, stressed religion and spirituality over race or politics as the basis of Slav commonality. After most of the original slavophiles had died, some of their ideas became politicized and formed part of Pan-Slav ideology. As an organized public movement, Russian Pan-Slavism received its first impetus from the Crimean $\mathrm{War}^{52}$. The humiliating defeat suffered by Russia in this war helped to transform a vague, romantic Russian Slavophilism into a militant and nationalistic Russian Pan-Slavism. One of the basic arguments of Russian Pan-Slavism after the Crimean War was that a diplomatically isolated Russia could attract the non-Russian Slavs as allies against a hostile West ${ }^{53}$. Prominent among the Russian Pan-Slav publicists were Rotislav Andreyevich Fadeyev and Nikolai Yakovlevich Danilevsky. Fadeyev held that it was Russia's mission to liberate the Slavs from Austrian and Ottoman domination by war and to form a Russian-dominated Slavic federation. Some Russian leaders, such as A. Hercen and M. Bakunin, advocated Pan-Slavism as a program of a united democratic Slavic state, where the Slavic partners would enjoy equal rights and would contribute to the creation of a common Slavic culture ${ }^{54}$.

After the Crimean debacle the Russian government concentrated on internal reform, retreated from international affairs, and tried to stay clear from involvement in the Balkans ${ }^{55}$. An outgrowth of the Slavophilism of the 1840 s, Russian Pan-Slavism had much in common with the older movement, yet was quite different. ${ }^{56}$ In the period after the Crimean War, Pan-Slavism in Russia reflected a mental process, that is, the hurt national pride by the War needed an outlet for its frustration. Pan-Slavism functioned as the outlet. The Crimean War stirred 
considerable interest among some upper class Russians in the condition of their Slav brethren abroad. These activists" established charitable organizations to aid the education of Balkan Slavic youth in Russian universities, as well as to advance these peoples' cultural and religious development. This effort manifested itself in the establishment of organizations such as the Slavic Benevolent Society, which founded the first chapter in Moscow in 1858.

To Pan-Slavs of Russia, the key criteria for membership in the nation were ethnic and political: race, language, shared culture and submission to Russian authority. Religion was also an important factor, but it did not play a central role. In a letter to the tsarevich Alexander (the future Alexander II) in 1838, Mikhail Pogodin wrote:

Our brothers and cousins, the Slavs, who are scattered over the whole of Europe from Constantinople to Venice, from Morea to the Baltic and the North Sea; the Slavs in whose veins the same blood flows as in ours, who speak the same language as we do, and who therefore, according to the law of nature, sympathize with us; the Slavs who, in spite of geographic and political separation, form by origin and language one spiritual entity with us ${ }^{57}$.

Blood, language, if coupled with religious faith, the formation of a Pan-Slav collective identity seemed just around the corner. More importantly, the contradiction between the Ottoman Turks and the enslaved southern Slavic nations was a target utilized by Pan-Slavs who claimed the unity of Slavs against foreign rule. Pan-Slavs believed that the alien, pagan Turks were the common enemy of all Slavs. The Russo-Turkish War 1877-1878 marked an upsurge in this ideological trend.

However, Pan-Slavism never succeeded to be an internationalist movement 
amongst the Slavs as a whole, including the northern and western Slavs, but had considerable influence among the southern Slavs, particularly in the Balkans, where the South Slavs had been dominated for centuries by Austria-Hungary and the Ottoman Empire. Influenced by Johann G. Herder, Slavic historians, philologists and folklorists inspired national consciousness among the Slavs, encouraging the passion for their shared history and identity. Pan-Slavism co-existed with the Southern Slavic national liberation movements, and particularly worked in the idea of South Slav unification.

After the collapse of the Balkan league around Serbia, Russian Pan-Slavs looked for a new strategic foothold in the Balkans. Following the victorious Russo-Turkish War of 1877-1878, Russia managed to establish an autonomous Bulgarian state. This was the birth of the San-Stefano Bulgaria mentioned above.

Contrary to the Pan-Slavic ideology, Bulgaria paid less attention to the unification of Slavs or Orthodox peoples in the Balkans against the Ottomans; rather, they pursued their own territorial gains from the alliance.

The major figures of the Bulgarian national revival, like Lyuben Karavelov and Hristo Botev were firmly against Pan-slavism. Karavelov stated that Pan-slavism is still in its cradle and thus it has no teeth to bite. All Slavic tribes are striving to build their own houses, to save their own heads and to protect their own existence; in a word, only those cabinet scientists and political theorists deal with Pan-slavism... the Bulgarian movement is neither Russian nor Serbian, nor Pan-slavist - it is only Bulgarian." 58 
Hristo Botev sharply criticized the ideology of Pan-Slavism in his article entitled Yugoslavia", which was published in his own newspaper Word of the Bulgarian Emigrants on July 17, 1871:

Will the Slavonic rivers flow to Russian seas, or will they dry out?... Neither Southern nor Western Slavs would sympathize with such an abstract idea of Russians, the implementation of which is to swallow the differences between the nations in terms of literature, manners and customs. On the contrary, neither Southern nor Western Slavs would not sympathize with the idea of South Slavs confederation without slavery nor amalgamation of different nationalities; contrarily, it is safe for the free development of these nations that make up the confederation.

The idea of both Karavelov and Botev demonstrated that of Bulgarian nationalists - they cherished the independence of the nation in terms of administration and nationality, fearing losing their national features and being integrated into or even annexed by big Slavonic nation.

In various historical periods, it was always possible for politically ambitious Slavs within Austria-Hungary or the Ottoman Empire to receive Russian support and aid if they adopted the Pan-Slav ideology. Thus the multi-national empires were continually under the threat of being destabilized both by nationalist claims for self-determination and by the Russian propaganda of Pan-Slavism. In turn, the Balkan countries were willing to make use of the ideology to achieve some purposes for their own good. Thus, as a cultural movement, Pan-Slavism played an active and progressive role in national awakening and liberation movements in the Balkans; as an ideology, however, it was vulnerable. The true unity advocated by Pan-Slavism could not be realized because the Slavs were involved in fighting each other over the leadership of the Slavs, and the Southern Slavs in the Balkans struggled openly or 
secretly over how to deal with Ottoman occupation. From the outside, Europe greatly feared Pan-Slavism as a tool of Russian domination, regarding Russian as the largest threat to peace in the East.

Pan-Slavism movement lacked effective organization, continuity, and cohesion, as well as solid ideology. Pan-Slavism, for example, had several prophets, including Dostoevsky and Nicholas Danilevsky, whose Pan-Slavic ideology remained an attitude of mind and feeling" rather than an -rganized policy or even a creed." In other words, in times of Balkan crises many Russians sympathized with the Balkan Slavs, but they forgot them once a crisis passed. As a political factor, Pan-Slavism was more a Western bugaboo than a reality ${ }^{59}$.

\subsection{Cultural identification versus political alienation}

After the Crimean War Bulgarian education raised a powerful national movement which evoked the national enthusiasm of the masses and achieved remarkable results. Due to the strengthened national business, the bourgeoisie was able to spend much more on education. In the form of donation and aid, Bulgarian merchants, industrialists and craftsmen built and equiped schools, paid teachers and sent Bulgarian youths to study abroad.

Meanwhile, the developing religious-national movement in this period also played a significant role because it caused competition with Greek education, urging Bulgarians to build schools and churches to defend their nationality, language and culture. 
As a powerful accelerator of spiritual revival, external culture and politics, particularly that of Russia, aroused the desire for modern education and culture among the Bulgarians ${ }^{60}$. Established in 1854, the Odessa Bulgarian Trustee - an organization of the emigrating bourgeoisie in South Russia, aimed to collect donations for Bulgarian schools and churches. On its initiative, many Bulgarian youths were attracted into Russia, and entered Russian schools, seminaries, colleges and universities. In 1865, the Russian government decided to establish a unified system for selecting and training the South Slavs in Russia. By an royal order, 5000 silver rubles were allocated for this purpose. Some special schools were appointed for the education of the South Slavs - Odessa School and Nikolaev University. In 1863, a boarding school for Bulgarian and South Slavic teenagers was opened in the city of Nikolaev. Moreover, many schools emerged under the patronage of Moscow, Kiev, Odessa, St. Petersburg and many other cities.

Nevertheless, the radical, democratic nationalism of the Bulgarian extremists was an entirely unwelcomed result of the Russian efforts to bring to birth a new Bulgaria $^{61}$. The students who were sent to Moscow, Kiev and Odessa were supposed to be educated with Slavophil ideas of salvation through Orthodoxy. Nevertheless, the results were not expected. Two of the foremost Bulgarian revolutionary leaders, Hristo Botev and Stefan Stambolov, had been educated in Odessa respectively in 1863-1865 and 1870-1872, but both were expelled for lack of interest in the school curriculum $^{62}$. A third, Lyuben Karavelov, when moved to Moscow through Odessa, did not stay at the cadet corps, in which he should enrolled, but became an auditor in 
the Faculty of History and Philology at the University of Moscow, where he fell under the influence of Russian revolutionary democrats. The subsequent careers of the three figures were leaders of the Bulgarian national revolution in different stages, and they were proved to be Russophobes.

From the Crimean War to the Liberation of Bulgaria, hundreds of young Bulgarians received education in Russia, among whom many became leaders of the Bulgarian Revival - Lyuben Karavelov, Hristo Botev, Vasil Drumev, Marin Drinov, Rayko Zhinzifov, Nesho Bonchev, Konstantin Miladinov, Konstantine Stanishev, etc. The Bulgarian education accepted from Russia new materials and moral weapons for the coming progress and development ${ }^{63}$. It was not unusual for Bulgarian elites, sponsored by Russian Slavic Societies on scholarship, to become closely acquainted with the radical ideas of Russian revolutionaries as an elective part of their formal education $^{64}$. Ironically, it was this facet of their Russian education that consistently influenced the future of Bulgarian revolutionaries in their work - ironic because these beliefs were quite opposite to those the autocratic government of Russia would have preferred that the Balkan Slav students acquire. Taking Lyuben Karavelov and Hristo Botev for instance, both fell under the influence of liberal Russian literature and radical revolutionary democrats when they studied in Russia. Both did not have pro-Russian political inclination in their revolutionary career during the Bulgarian liberation movement. Rather, they kept their distance with Russia's political propaganda for fear of being exploited. In a word, they accepted Russian cultural ideologies and revolutionary ideas, while rejecting Russia's excessive political 
interference and manipulation.

In addition to cultivating the Bulgarian national intelligentsia, the support of Russia also focused on sending books and supplies to Bulgarian schools and granting special funds for schools in disadvantaged areas. Russia translated not only ideological propaganda, but also universal European values to Bulgaria. This is evident in the linguistic sphere ${ }^{65}$.

To sum up, relations between Russia and Bulgaria are marked by their closeness in alphabet, language, culture and religion. They used a common script - Cyrillic, on the basis of which their own alphabets were developed. In the tenth and eleventh centuries, Bulgarian Orthodox culture served as the foundation for Russia's nascent culture, whereas the Russian variant of the common cultural tradition played a crucial role in the revival of Bulgarian culture and language in the late $18^{\text {th }}$ and early $19^{\text {th }}$ century. From the beginning of modern education for the Balkans in the early $19^{\text {th }}$ century, Russian culture and ideas had dramatically influenced key developments in the history of Bulgaria, such as the emergence of nationalism, liberalism, and even constitutionalism. The cultural closeness between Russia and Bulgaria helped to accomplish the enlightenment of the Bulgarian nation on the one side, and on the other side was a support for Russia to fulfill its national strategy in the Balkans.

Politically, however, Russia played a dual role in the formation and development of Bulgarian nationalism. Both the ideology of Pan-Slavism and its support to the Bulgarian national liberation movement were of significance in the awakening of the national consciousness. Putting its selfish strategic consideration aside, Russia indeed 
played the role of supporter, protector and liberator in the course of Bulgaria's fight againt the Turkish rule. However, driven by their own political and diplomatic interests, Russia‘s Balkan strategy often showed contradictions on different Balkan issues, which was always counterproductive. Also due to Russia's inconsistent and indecisive diplomacy to Balkan states, the conflicts among the Balkan nations were exacerbated, particularly in the issues relating to territorial division, and it planted a seed for the subsequent ethnic contradictions.

Furthermore, because of their own political weakness, the Bulgarian national activists constantly sought the help or support from the Great Powers and major power groups. They cast themselves on different powers or groups at different times, enabling the powers to intervene in the affairs of the Balkans. This was the fatal weakness for the nation. Unfortunately, the Bulgarians were not backed by Russia solidly as is often assumed. Just as Stavrianos analyzed, Russia was generally sympathetic with the Bulgarian aspirations but at the same time she wished to avoid a schism and to avoid alienating the Patriarchate and the Greeks."66

\footnotetext{
${ }^{1}$ In this chapter, I use secondary sources for special aspects of the history of inter-state relations between Russia and Bulgaria. The central texts in my documentation of the key events are: Jelavich, Charles. (1958). Tsarist Russia and Balkan Nationalism: Russian Influence in the Internal Affairs of Bulgaria and Serbia, 1879-1886. Berkeley and Los Angles: University of California Press; Riasanovsky, N. V. (1993) A History of Russia. New York, Oxford: Oxford University Press; Georgieva, Tsvetana \& Genchev, Nikolai. (2006) History of Bulgaria XV-XIX, Sofia: Anubis. ${ }^{2}$ Charles Jelavich: Tsarist Russia and Balkan Nationalism: Russian Influence in the Internal Affairs of Bulgaria and Serbia, 1879-1886. Berkeley and Los Angles: University of California Press, 1958, p. 3 .

${ }^{3}$ Wesley Gewehr: The Rise of Nationalism in the Balkans, 1800-1930. New York: Henry Holt and Company, 1931, p. 3.

${ }^{4}$ That is that the European states, particularly the great powers at the time, should remain in a state of rough equilibrium. When one gained a territorial extension, then the others should receive an equivalent compensation.
} 
${ }^{5}$ Constantinople was the capital of the Ottoman Empire at the time. The collapse of the Ottoman Empire gave hope to the European powers for the division of the territory that the Constantinople controlled. The Russian officials desired to divide up some Ottoman territory in the Balkans and then control the destiny of the entire Ottoman empire.

${ }^{6}$ Charles Jelavich: Tsarist Russia and Balkan Nationalism: Russian Influence in the Internal Affairs of Bulgaria and Serbia, 1879-1886, 1958, p. 57.

${ }^{7}$ Carlton J. H. Hayes: The Historical Evolution of Modern Nationalism, New York: R.R. Smith, 1931, p. $59-60$.

8 This term was developed from the idea of Volk, translated into English as the people or the nation.

9 Hans Kohn: The Idea of Nationalism: A Study in Its Origins and Background, New York: The

Macmillan Company, 1944, p. 437-438.

${ }^{10}$ Cited in Stavrianos: The Balkans since 1453, New York, 2000, p. 227-228.

${ }^{11}$ Cyril Black: Russia and the Modernization of the Balkans", in Charles Jelavich, ed. The Balkans

in Transition: Essays on the Development of Balkan Life and Politics since the Eighteenth Century, 1963, p. 147.

${ }^{12}$ Barbara Jelavich, - Fsarist Russia and Balkan National Liberation Movements: a Study in Great-Power Mythology", in R. Sussex and J. C. Eade, ed., Culture and Nationalism in

Nineteenth-century Eastern Europe, Columbus: Slavica Publishers, 1985, p. 56.

${ }_{13}$ Lyuben Karavelov: Freedom and Independence. Edited by Granitski, Ivan and Anchev, Panko.

Sofia: Zaharii Stojanov, 2003, p. 434-435.

${ }_{14}$ In this section I have to mention repeatedly the events of historical importance in the Bulgarian National Revival, the purpose of which is to show the place of Russia in these events instead of reviewing comprehensively the evolution of Bulgarian nationalism in the previous chapter.

${ }^{15}$ Charles Jelavich: Tsarist Russia and Balkan Nationalism: Russian Influence in the Internal Affairs of Bulgaria and Serbia, 1879-1886. Berkeley and Los Angles: University of California Press, 1958. p. 3.

${ }^{16}$ The Bosphorus and the Dardanelles - the two straits separating Europe from the mainland of Asia, connecting the Black Sea to the Mediterranean Sea.

${ }^{17}$ Charles Jelavich: Tsarist Russia and Balkan Nationalism: Russian Influence in the Internal Affairs of Bulgaria and Serbia, 1879-1886, 1958, p. 3.

${ }^{18}$ The Eastern Question refers to a series of political and diplomatic problems emerging around the decline of the Ottoman Empire.

${ }_{19}$ Georgieva \& Genchev: History of Bulgaria XV-XIX, , 2006, p. 479.

${ }^{20}$ The Holy Alliance was a coalition of Russia, Austria and Prussia created in 1815 at the behest of Tsar Alexander I of Russia, signed by the three powers in Paris in 1815 after the defeat of Napoleon.

${ }^{21}$ Of the many Christian sites within the Ottoman empire, the most significant were those in Palestine - in particular the church of the Holy Sepulchre in Jerusalem and the church of the Nativity in Bethlehem.

${ }_{22}$ Moldavia and Wallachia were Ottoman-controlled provinces on the banks of the Danube River.

Previously, Russia had obtained from the Ottoman Empire recognition of their role as special guardian of the Orthodox Christians in the provinces.

${ }_{23}$ B. H. Sumner: Russia and the Balkans 1870-1880, Hamden, London: Archon, 1962, p. 3.

${ }^{24}$ See particularly Sumner: Russia and the Balkans 1870-1880, p. 105-106.

25 See F. P. Fonton, Vospominaniya (Leipzig, 1862), vol. Ii, pp. 71-73, 180,195.

${ }^{26}$ For details, see the four volumes of Naiden Gerov's private and official correspondence, in which Russo-Bulgarian relations after the Crimean War were mentioned very often.

${ }^{27}$ Ibid.

${ }^{28}$ In Bulgarian they were called -Revolutionary actions".

${ }^{29}$ See Gerov's letter to Stremoukhov, Dec. 21 1867, text in Iz Archivata na Naiden Gerov, vol. ii, p. 287: for Bulgarian plans for co-operation with Serbia and Russian relations with the Bulgarians in 1867.

${ }^{30}$ Peter Dimitrov-Rudar: In Search of the Truth-About the Detachment of Hadji Dimitar and Stefan Karadjata. Sofia: Pensoft, 2001, p. 15.

31 B. H. Sumner: Russia and the Balkans 1870-1880, 1962, p. 113.

${ }_{32}$ See citations from newspapers in Chapter IV.

33 Ma Xipu: The History of Bulgari, 2011, p. 103. 
${ }^{34}$ Cited by Stavrianov in his work The Balkans since 1453, p 379.

35 Stavrianov: The Balkans since 1453, p. 380.

${ }^{36}$ See details in The Balkans since 1453, p. 404-406.

${ }^{37}$ For the details of the Treaty of San Stefano, see Chapter II.

38 See The Balkans since 1453, p. 409.

${ }^{39}$ Charles Jelavich: Tsarist Russia and Balkan Nationalism: Russian Influence in the Internal Affairs of Bulgaria and Serbia, 1879-1886. 1958. p. 3

${ }_{40}$ An agreement made between the Austrian Empire and Russia in July 1876.

${ }^{41}$ Stavrianov: The Balkans since 1453, p. 409.

${ }^{42}$ Ibid, p. 411.

${ }^{43}$ The words were from a letter of Disraeli to Derby. The original sentence was -Sal, seems most prejudiced and not to be aware that his principle object in being sent to Const. is to keep the Russians out of Turkey, not to create an ideal existence for Turkish Xtians." See in Disraeli by Robert Blake, p. 616.

${ }^{44}$ Under Art. 25 of the Treaty of Berlin, Austria-Hungary received special rights in the Ottoman Empire's provinces of Bosnia-Herzegovina and the Sanjak of Novi Pazar. The Art.25 stated: The provinces of Bosnia and Hercigovina shall be occupied and administered by Austria-Hungary".

${ }^{45}$ On October 6, 1908, when Austria announced the annexation of Bosnia and Herzegovina the Bosnian Crisis erupted.

${ }^{46}$ Citations of Ivan Bozic, Yugoslavian historian in The History of Bulgaria by Ma Xipu, p. 107.

47 Stavrianov: The Balkans since 1453, p. 412.

${ }^{48}$ Barbara Jelavich, Fsarist Russia and Balkan National Liberation Movements: a Study in Great-Power Mythology", in R. Sussex and J. C. Eade, ed. Culture and Nationalism in Nineteenth-century Eastern Europe. Columbus: Slavica Publishers, 1985, p. 63.

${ }^{49}$ Milan Obrenović (1854-1901), Serbian monarch reigning as Prince Milan IV of Serbia from 1868 to 1882 and King Milan I of Serbia from 1882 to 1889.

${ }^{50}$ Hans Kohn: Pan-Slavism: Its History and Ideology, New York: Vintage Books, 1953, p. 1.

${ }^{51}$ Slavophilism was an intellectual trend that emerged in Russia in the late 1830s. Its leaders included Aleksie Khomiakov, Ivan Kireevsky and his brother Pyotr, Konstantin Aksakov, and Yury Samarin. While there were differences among these thinkers, they all responded to the ideas espoused by another group, the Westernizers, of transnational culture and identity and to the process of Westernization with its accompanying secularization. The Slavophiles sought to define their nation as unique and fundamentally different from Europe: Russia thus had to follow its onw principles and its own path of development (Lantz 2004, 397).

52 Michael Petrovich: The Emergence of Russian Pan-Slavism, 1856-1870, New York: Columbia University Press, 1956, p. 129..

${ }_{53}^{53}$ Ibid, p. 246.

${ }^{54}$ George J. Lerski: Historical Dictionary of Poland, 966-1945, Westport: Greenwood Press, 1996, p. 419.

${ }_{55}$ Mari A. Firkatian: The Forest Traveler: Georgi Stoikov Rakovski and Bulgarian Nationalis, New York: Peter Lang, 1996, p. 14.

${ }_{56}$ Petrovich: The Emergence of Russian Pan-Slavism, 1856-1870, 1956.

${ }^{57}$ Cited in Astrid Tuminez: Russian Nationalism since 1856: Ideology and the Making of Foreign Policy, Rowman \& Littlefield Publishers, p, 70.

${ }_{58}^{58}$ Lyuben Karavelov: Freedom and Independenc, 2003, p. 393-394.

59 Riasanovsky: A History of Russia, 1993, p. 450..

${ }^{60}$ Georgieva \& Genchev: History of Bulgaria XV-XIX, Sofia: Anubis, 2006, p. 402.

${ }^{61}$ B. H. Sumner: Russia and the Balkans 1870-1880. Hamden, London: Archon, 1962, p. 111.

${ }^{62}$ Botev was deeply impressed by the work of the liberal Russian poets of the day and established strong connections with the Russian and Polish revolutionary movement; Stambolov also established a lot of connections with Russian revolutionists.

${ }^{63}$ Georgieva \& Genchev: History of Bulgaria XV-XIX, 2006, p. 403.

${ }_{64}^{64}$ Firkatian: The Forest Traveler: Georgi Stoikov Rakovski and Bulgarian Nationalism. 1996, p. 14.

${ }^{65}$ There is a detailed discussion on the linguistic influence of Russian upon Bulgarian in Chapter IV.

${ }^{66}$ Stavrianos: The Balkans since 1453, 2000, p. 373. 


\section{CHAPTER 3 PUBLIC POLICY AND ITS REFLECTION}

\section{IN BULGARIAN MEDIA}

The previous two chapters review the rise of Bulgarian nationalism and Russia 's role in the process from the perspective of historiography. But in general, national politics, strategies and diplomacy were manipulated merely by the leadership and a few political elites. What an academic history cannot do is to demonstrate the public will by journalistic records. In this chapter, some articles from Bulgarian newspapers in the discussed time will be interpreted in order to show the public approval or disapproval, acceptance or rejection, praise or blame to the decisions of policy makers.

The Bulgarian periodical press appeared at the turn of the $40 \mathrm{~s}$ in the $19^{\text {th }}$ century. By the mid 1860s over fifty different newspapers and magazines had been published both in Bulgaria and over the border. Most of the publications of the time, particularly those published in the Ottoman territory, basically did not carry articles that could be considered subversive or belligerent. Tsarigradski Vestnik (Constantinople Newspaper 1848-1862), for instance, described events and commented in the tone of the Ottoman authority. Most newspapers were concerned with cultural or political events of the day and carried articles similar to those in the columns of most other European newspapers, without showing the real voices of 
Bulgarians under the foreign rule. Fortunately, some Bulgarian newspapers published over the border of Bulgaria were more often concerned with the hot spot issues related with Bulgaria, expressing their national opinions.

The author picks mostly the speeches of some national elites, represented by Georgi Rakovski, Lyuben Karavelov. Rakovski was the first ideologist and organizer of the Bulgarian national liberation movement; his extensive experiences and theoretical ideas were well inherited by later generations in their struggle. Karavelov was a writer and an important figure of the National Revival. He contributed significantly to the intellectual movement of the Bulgarian community at the time. His political claims experienced a changeover from the idea of the unification of South Slavs to that of national self-liberation. The journalisms (?) being examined in this chapter are mainly from the newspapers edited by the two figures - Danube Swan (Дунавски лебед) by Rakovski, Liberty (Свобода) and Independence (Независимост) by Karavelov (including a numbers of unsigned materials). To show the public opinion objectively, some texts of other then influential newspapers are interpreted as well. The major ones among them are Nationality (Bucharest), Bulgarian (Bucharest and Giurgiu, Romania) and Slavonic Brotherhood (Bucharest).

The Russo-Turkish War in 1877-1878 and its aftermath, particularly the two treaties played a vital role in developing Bulgarian nationalism. The major result of the war was Bulgaria being recognized as an independent state; even more importantly, Bulgaria, as a state with independent nationality was re-recognized in the world community, which represented a great victory in the evolution of the 
Bulgaria nation. In this course, the help from Russia and its forces could not be denied in any case. But as early as the years before the war, in the Bulgarian community there were many rational suspicions and worries about Russia's real intention in the liberation of Bulgaria. This epitomized one side of the Bulgarian nationalism, that is, fear of being dominated by the savior.

\subsection{Urgent requirement for the independence of the Church}

For several centuries the Bulgarian Church was under the jurisdiction of the Patriarchate of Constantinople. During the five-centry-long Ottoman rule, the Turks directed their religious policy against the Orthodox-Christian faith of the subjugated population and tried to assimilate them. The Bulgarian people firmly abode by the faith of their ancestors, and this helped them to preserve their nationality.

To establish an automonous Bulgarian church free from Greek ecclesiastical domination became a major goal. According to the Ottoman millet system ${ }^{1}$, the Orthodox Christians were included in a separate confessional community with a certain degree of certain autonomy. Despite their difference in ethnicity and language, Orthodox Greeks, Bulgarians, Albanians, Vlachs, Macedonian Slavs, Romanians and Serbs were all part of the same millet dominated by the Greek Church. The system made Greek domination possible. Thus, when the Bulgarian national revival began, the first foe of the Bulgarian nation was not the Turks but rather the Phanariot Greeks $^{2}$. The Bulgarians, unlike the Romanians and Serbs who first gained political 
independence and then sought for separation of their respective churches from the domination of the Constantinople Patriarchate, attempted the reverse way.

The Treaty of Paris of 1856 , as the end of the Crimean War, weakened the international influence of Russia in Europe and exacerbated the Eastern Question. As for the Bulgarians, the Treaty showed that they could not place their hopes on direct change of the political status quo, and again they should focus their efforts to achieve cultural and spiritual autonomy.

On the Church issue, Rakovski spared no effort. In 1860, Rakovski came to address the Bulgarian Church question:

The worst is that ... the Bulgarian question was being manipulated by the Russians... Russia not only has not advanced this question but has from the beginning of its appearance showed herself as its biggest opponent ... she has acted the most through her agents in Constantinople so that the Bulgarians are not separated from the Greek spiritual power, and remain submissive and slaves of the Phanariot Patriarch. $^{3}$

Early in the middle of $1860 \mathrm{~s}$, when the uprising in Crete $^{4}$ broke out, the Ottoman Sublime Prote planned for the final settlement of the Greek-Bulgarian church relations. In this situation, with the assistance of General Ignatiev, the Project 1867 of Patriarch Gregory VI was published. It foresaw the autonomy of the Bulgarian Church, but only within the scope of Danube Bulgaria. Bulgarian representatives, however, rejected the patriarchy project, insisting on respecting the historical and ethinic rights of the Bulgarian nation. This demostrated their fierce determination to have a united Church of the nation.

Russian diplomacy after the Crimean War intervened in Greek-Bulgarian 
relations actively. She continued to adhere to the archaic canon that the unity of Christians in Turkey should be definitely ruled by the Patriarchate of Constantinople. In an official note in 1858, the general principles of Russia on the Eastern Church were that Russia defended the entire Patriarchate of Constantinople, and she would not allow in any case independence and separation from the Patriarchate of Constantinople $^{5}$. Thus, the thesis for Orthodox unity already entered into a sharp contradiction with the principle of nationality, and the Russian policy was opposed to the Bulgarian national aspirations, which greatly undermined Russia‘s influence in Bulgaria, as well as enabled the West to strengthen religious actions in the Eastern Question.

Since the late 1830 s, the main task of the Orthodoxy unity became the guiding principle for the Russian Eastern diplomacy. That was why Russian diplomats turned a blind eye to Bulgarian revolts against the Greek clergy. But in the next few years, when the church movement became real, and when the Bulgarian national activists established contacts with representatives of the West, Russia intervened vigorously.

The response of the Bulgarians to Russian policy on the Church question could be found in the newspaper Nationality at the time. A report entitled The answer of the Russian Synod to Bulgarian Church Issue" published on June 1, 1869 said:

It was notified from Constantinople on May 29 (1869) that Saint Petersburg's Synod clarified through a letter to the Greek patriarch, to leave the Bulgarian Church question in its status quo (viz, the patriarch not to make any concession to Bulgaria and to leave as it was.)"

Here we have finally seen the formal expression of Russian Synod against the Bulgarian people's request for independence of the Bulgarian Church... Now we finally see in the letter the evidence of the wrongfully support from Russian Synod to 
Constantinople Patriarch. I am delighted that we could see the Russian Synod's hostility to our legitimate aspirations, because the Church issue will be more simple to solve. Our people, who have become incredulous due to the sufferings, will make sure through this case that only the government of St. Petersburg agreed with Sublime Porte to abstain the solution of our Church problem. St. Petersburg's cabinet has such a huge interest because they cannot bear to see this issue resolved; because they know that this solution will give a new direction to the life of our nation ...now for her (Russia) the division of Christians means nothing other than the possibilities of being able to command them more easily. ${ }^{6}$

Another special review appeared on the front page of the newspaper on June 8, discussing the Bulgarian church question:

The Bulgarian Church question, a daily occupation of the Bulgarian people for many years, began to show its importance for the outside world as well. Many foreign newspapers get interested in this question... Russian Synod clarified: it is not the right time to recognize the independent Bulgarian church, instead, the unity of the whole Orthodox Church is necessary and very urgent because it would be powerful against the Turkish supremacy. ${ }^{7}$

In order to suppress the negative attitude of Russia on the independence of the Bulgarian Church, Bulgaria turned to other Western Powers for help:

The first successes of the Bulgarian Union caused great expectations among the European Catholic world. Committee of Supporting the Bulgarian Union" has been established in Paris. In Italy, the subscription for its funding is also to be opened. In the 60s, a few books dedicated to Bulgaria have been published in the West. In Constantinople, Coodinating Council on Union Question was founded, headed by apostolic vicar Brunoni who has task to lead the Bulgarian Union movement. Since the mid 60s, the French and Austrian diplomacy began to stand on the Bulgarian side. But both their Catholic propaganda and their efforts to discredit Russia failed; Russia still insisted on her argument on Orthodox unity. In Bulgarian society, there are a group of Westerners who believe that the Bulgarian question can be decided felicitously by cooperation with the West, and think that only the Union can exert effective pressure on the Russian intransigence, and thus accelerate the Church independence process. ${ }^{8}$

In the issue of $31^{\text {st }}$ the same month, they asserted the determination of the Church independence. 
Here we want to say that today the Bulgarian people are facing the same fate with their own Church question. Whoever says whatever about today's situation of the Bulgarian people, the core of our cause will be nothing but acquiring an independent church. ${ }^{9}$

As a result of extensive and organized struggle of the Bulgarians for spiritual separation, in 1870 , by a decree (firman) of the Sultan, the Ottoman government restored the once unlawfully destroyed Bulgarian Patriarchate under the name of "Bulgarian Exarchate". The Bulgarian Church thus won international juridical recognition of this nation before the world, and consolidated it ethnically, spiritually, culturally, historically, territorially and, to a certain degree, politically.

Even after the Russo-Turkish War, when Bulgaria obtained liberation, any question about the independence of the Bulgarian Church put the Bulgarian press on the defensive. An article in the issue of Bulgarian on July 16, 1878 showed firm opposition to Russia's initiative to put the Bulgarian Church under the jurisdiction of the Russian one.

Malicious rumors about the bad relations of the Russians with the Bulgarians and the covered purpose, for which Russia launched the latest war, are unceasingly spread everywhere. This very much delights our rivals and enemies. We recently read in Bucharest Oriana, a correspondence in Ruschok, something that said that Russia wants to take away the religious liberty of the Bulgarians, i.e., the Bulgarian Church be subordinate to the Church of Saint-Petersburg, and also to replace the Bulgarian priests with Russian ones. This is evidently a slander from correspondence of our brother. It would not be highlighted but for the purpose of provoking resentment and hatred against our liberators who had never allowed this to happen.

Let us suppose for a moment that the Russians actually intend to take away our religious liberty, and put us under their spiritual superiority. If our fellow Russians want us to speak directly and naively, then we will have no reason to be angry later on-we will tell them that their efforts will go crazy and their works will remain useless. The Bulgarians are devotional, but not that fanatic, with moderate belief. No matter what persecutions the Bulgarians suffered from, they never lose the beginning of the faith, the faith that left them their first Saints and educators who have turned them into Orthodox Christians. It is a fact that no purpose will succeed if the 
Bulgarian faith is taken for weapon. What kind of means has not been used by the Turks for centuries to make us followers of Mohammad...? Not effective. The Bulgarians love to follow and believe what they had chosen themselves. This is, perhaps, their weakness, but this is true. They comply with their Christian duties with moderate devotion...

No propaganda has been able to succeed in Bulgaria; no imposed opinion has been able to be accepted, and we bet this will not happen in the future either.

Indeed, we have learned that certain change in our Orthodox church is necessary in some manner, but we will do it willingly, without interference from anyone else. The ministry of our own has long expressed the wish for that. ${ }^{10}$

For the Bulgarian Orthodox Christians, the independent Bulgarian Church meant the recognition of the Bulgarian population as a Bulgarian nationality and as a Bulgarian nation, separate from the Greeks; it was also where the hope and prerequisite for the restoration of the independent Bulgarian state would be. Thus, the Bulgarians accepted the fact of being protected by Russia during the later stage of the Ottoman rule, but once the Russians made further claim to deprive them of the independence of the Bulgarian Church, the bottom line of the Bulgarian national psychology was broken. From the reflection of the Bulgarian public opinion to this rumor, the national wish of the Bulgarian people was expressed clearly-- they would not allow their liberty, both physically and spiritually, to be dominated by any foreign power, fellow or enemy.

The Bulgarian presses feared Russia's manipulation of Bulgaria, both politically and spiritually. Such sentiments were often concealed by the gratitude to Liberator Russia, but they had been always lurking around every corner of the Bulgarian national consciousness. National sentiments gradually developed into tension between the two countries, and thus influenced the directions of the national selection in the following historical events. 


\subsection{Pre-state of April Uprising}

In 1840s, the Bulgarian peasants could not bear the Ottoman tyranny, and this developed into armed protest against uncontrolled greed and excessive taxes. The rise of the peasants in Vidin recorded the despair and the intolerable regime, for which a protocol of Vidin District Council on August 18, 1850 revealed that the land of some villages was not given to the local people but was distributed in a form of bond to Muslims living in the district. The holder-Muslims themselves, however, gave the land to the local residents for rent. Pasha also had right to levy high tax on sheep farming, forest, as well as vineyard." Added to this legalized extortion were numerous other taxes which were illegal to Aghas ${ }^{11}$ and officials.

Besides economic oppression, the Bulgarians felt humiliation on their national spirit. There were no guarantees for life nor for honor of a man and his home, which Bulgarian peasants were fond of owing to patriarchal tradition.

The complaint of villagers from Rakovitsa and Gramada revealed how Bulgarians opposed the endless worries: We are all frustrated by civil servants ... It should be noted that we will not allow rural Aghas to come to our village. We can no longer tolerate their crimes. We do not want Muslims moving to our villages because they touch the honor of our daughters and boys. We are ready to sacrifice, but we do not want violence on us. We do not want anyone the Muslims who scurried around our villages and torture us... When we hear that soldiers come to our villages, everyone runs like partridge." ${ }^{12}$ The antagonistic sentiments of rural people were 
increasing also because of the revolutionary propaganda, spread by agents of the Serbian principality.

Both material poverty and spiritual oppression afflicted Bulgarians, which led to the fact that they intended to change the status quo, though lacking of effective channel and approach. As a result, a numbers of Bulgarians had to flee their homeland for subsistence. An article published in Liberty on August 5, 1872 described the miserable condition, and drew out the deep-seated cause:

Taxes, imposed recently on the people, have reached such enormous proportion that the inhabitants of the most productive and most prosperous landlords could not pay them. A reporter described the situation of our people: The government has decided to ruin people and make them capable of nothing. On the one hand, they are killing us materially; and on the other hand, ethically. The people are utterly bereft, and a naked person will never think about their intellectual development. In the last three years, the Bulgarian peasants were forced to endure hunger and poverty. But the government did not pay any attention to this and increased taxes continuously. At present, the tax rate is no long one fifth, but $60 \%$. Certainly, farmers were unable to pay these heavy taxes and then more cruel things took place in villages that all sheep were looted."

... This is the situation of the Bulgarian people; but the government wants more, offering no aid... Tell me now, what should the people do to get rid of these severe pains and inhumane sufferings? I know that you will say: Eet us protest, rise and fight! But do you know that a struggle requires mental development. But our people are dull and besotted to the extreme. Only Constantinople rascals sermon that salvation has been locked in schools. Come and teach our people if you can! Many Bulgarian families have moved to Serbia just for a piece of bread and peaceful sleep. "... meanwhile, we cannot withhold to find out who are at fault in the hopeless wrong. So we may freely say that the main enemies of the Bulgarian people are Bulgarians themselves, i.e., the wealthy, our teachers, educators, priests, bishops, publicists, and Turkish officials in particular ... We must organize our people for beating our enemies mentally. ${ }^{13}$

This article also showed us why the Bulgarian National Movement originated from cultural revival rather than a political one. The long-last alien political power and assimilation had pulled down their ambition for being liberated by the people 
themselves; the only way was to awaken the people's spiritual sense of independence and to remind them of their brilliant cultural heritages.

\subsection{National Liberation: relying on the Great Powers or self-strengthening?}

At one time, the Bulgarian nationalists placed hopes on the reform of the Sublime Porte, but they were getting impatient. In the fiftieth issue of Danube Swan on September 13, 1861, Rakovski complained:

Nothing seems to have moved the Turks to act on the Hatti-Humayun ${ }^{14}$, not a note from Gorchakov, ...from the French, the Austrians... who warned that unless the Hatti-Humayun is realized, the existence of the Turkish kingdom is in danger. The people, oppressed to the utmost by Turkish atrocities, are beginning to think and to be convinced that from such notes and letters no help is coming. ${ }^{15}$

An article entitled -Gaze to the East" in the same issue described the state of the Sick Man of Europe, - - what can even the most outstanding doctor in the world do for one decrepit, gangrenous old man, attacked simultaneously by twenty illnesses?"

Losing their faith in the Sultan's ability to carry out reform, the Bulgarian nationalists tended to hope for European reaction which would concern any Bulgarian national attempt to win liberty from the Turks. Rakovski wrote in the 54th issue of Danube Swan on October 10, 1861, it is understood that when Europe sees a people who fight heroically with their tormentors for their sacred rights and freedom, and that they are worthy of her, ....she ${ }^{16}$ will not stand to allow such injustice, but will help the weaker as with the Greeks, when they were fighting for their liberty." Obviously, Rakovski was impressed by Great Powers' precedent 
intervention in the Balkan national issue represented by national revolt, at least by its efficacy.

However, Rakovski was not very confident in the philosophy of relying on the Great Powers to resolve the problems of the ruled Balkan nations, from which he vacillated to another philosophy, that is: for they themselves to decide the question and to become masters of their own homeland. They must all concentrate on one and only one path; when they have strengthened themselves then no one will be able to dispense with them at his will.",17

Another article published in Liberty demonstrated more clearly the controversy between these two philosophies:

We should not shed blood and sacrifice young strength to Bulgaria because Turkey itself is waning; we are its legitimate heirs," many diplomatic minds are saying and thinking that the nature is ready to throw roasted fowls from the heaven to their mouths. - $\$$ do not need insurrections, nor sacrifices, because Russia 's railways have not been ready," said those who learned to expect almost everything from foreign hands and to be fed in foreign kitchen. - Our people are not mature yet," said our leaders, expecting happy days. If you ask us, we may answer unhesitatingly that if everything keeps going in this way, our people will be mature only when they disappear from the world. ${ }^{18}$

Bulgaria's reliance on external forces for support and help was not confined to the Great Powers. The nationalists were aware that the hundred-percent way to achieve national liberation was to launch armed struggles; in addition, they considered various schemes which involved federation, confederation, or some other form of Balkan unity as an instrument for liberation. To them, the idea of some form of unified Balkan action or movement seemed to be more reliable than fighting alone 
or relying blindly on the Western Powers. Thus, the idea of Balkan union won a considerable number of supporters.

In an article entitled Balkan Nations Should Unify Their Own Strength", Karavelov appealed:

To liberate our countries from foreign yoke, we should closely unite our forces and mental abilities, just like one person ...Everyone of us understands that we have too many external enemies who will be defeated only when the Bulgarians, Romanians, Serbians (and Greeks?) closely unite our own forces, and only when we fight with the habits hidden in our national characters which could not be boasted with the development of education; in a word, we will insure that our interests are inextricably tied together. We cannot survive without each other - our enemies are so many, and we are so few in number. ${ }^{19}$

An article published in Independence on October 5, 1874 called on the South Slavs to bond themselves together:

A Croatian newspaper review presented a very long article dedicated to the South-Slav movements. This article, along with the last two correspondences of our Constantinople correspondent, made us talk about today's position and future events in the Balkans again. The author of the article above also sent an idea that the Greeks will never be the friends and allies of the South Slavs ... So our long-standing conviction becomes common among the South Slavs ... and Serbia is due to remove doubts appearing in recent years in the sphere of South Slavic union. ${ }^{20}$

Karavelov actively advocated establishing a Balkan federation or confederation for achieving both respective national independence and peaceful coexistence. The federation in his idea was comprised of Serbia (including Bosnia Herzegovina and Montenegro), Romania, Bulgarian (including Thrace and Macedonia), Albania, Greece (including Thessaly and Epirus), and city of Constantinople in freedom. In the framework of the federation, Bulgaria, Serbia and Romania would form a tight union with a common parliament, but their executive powers would be exercised 
respectively. Although the idea of Balkan federation was not realized, it exerted a positive impact upon Balkan national liberating movements.

\subsection{Ambiguous attitude toward Russia - hopeful and incredulous}

On July 21, 1872, the newspaper Liberty in Bulgarian issued in Bucharest published an article entitled If Russia comes as a liberator", saying that -Russia has started to look at the South Slavs in a different way only because he has made an agreement with Austria and because he hopes to achieve his long-standing plans on the Balkan Peninsula."21 The article called on the Balkan states to band themselves together, aiming at forcing the Russians to concentrate their forces on other regions: If Serbia and Romania gain strength and independence, and if Danube or South Slav Federation come into being, Russia is obliged to give up his dreams and turn all his attention to the Asian deserts." Furthermore, it gave examples to prove Russia's insincerity with the Balkans: The migration of Tatars in Turkey, the Russo-Turkish friendship, the trip of the prince Milan in Constantinople, etc, testified very clearly that Russia did not want well-being of the South Slavs at all."

If Russia comes to the Balkan Peninsula as liberator and savior, the Slavic brotherhood will be an accomplished fact; but as if she comes as a ruler and rude despotic power, before which everyone falls to his knees, then her successes will differ from the first case ... In a word, Slavic brotherhood will be realized only when every Slavic tribe is free and independent, when each Slav can protect the distinctions, manners and customs of his own tribe ... But we have already said that it will not be very soon, so the southern and western Slavs have to think about their present and protect their future from numerous Slavic enemies who have recently grown into an incredible figure. ${ }^{22}$ 
This indicates the national psychology of the Bulgarians - when Russia played a role of liberator and protector against Ottoman control, Bulgarian and Russian national myths went hand in hand. The Bulgarians willingly appealed to and accepted Russian military aid because of the common religious and humanistic principles. Once the goal of national liberation had been achieved, the Bulgarians would no longer want to be manipulated by Russia, either militarily or politically.

There was a time when the Bulgarians crossed arms, waiting for the Russian army to expel the Turks and to return to the people their rights and to give them liberty. In a word, waiting for God to come down from the Heaven and put roasted sparrows into their mouth. But year after year, the people were still suffering from all kinds of pains, with no help from anywhere. Under such circumstances, each Bulgarian man should understand that, firstly, every nation should work for itself, i.e. to make its efforts and then seek sympathy or assistance from others; secondly, liberty is being taken rather than given. Any almsgiving loses both its good and its value extremely soon. We have thousands of examples like this ${ }^{23}$.

As can be seen from this passage, the Bulgarians had placed much hope on Russia's help for national liberation, but they did not achieve the goal until then. The national revolutionists reminded the people that the given liberty" would lose its original value very soon, and thus awakened them to gain liberation through their own endeavors. This implied that Russia would reveal his real intentions and ambitions right after helping Bulgaria being liberated from the Ottoman Turkey.

Even though the Bulgarian elite seemd clear about Russia's ambition, Bulgaria, as an underprivileged nation without either government or forces of his own, needed the help of the Russian forces, and take advantage of the profitable situation caused by the military conflict between Russia and the Ottoman Turkey. This seemed the only way to realize national liberation and independence. Therefore, as early as April 
24, 1877, when the Tsar Alexander II of Russia declared war on the Ottomans, the Bulgarian Revolutionary Central Committee ${ }^{24}$ called on the Bulgarians to arm themselves, helping the Russian forces to face battles. In the course of the war in a few months, a volunteer corps and militia of nearly ten thousand were organized. They worked together with the Russian militaries, helping them in investigation, translation, medical service and food and ammunition delivery. More than that, they took part in the battles in Stara Zagora, Shipka, Rodopi, Dobrudja and etc, assisting the Russians against the Turkish army from the rear ${ }^{25}$.

During the Russo-Turkish war, the Bulgarian media still showed a wait-and-see attitude - both grateful, hopeful and incredulous, equivocal, which represented the fear of the potential detrimental consequence after winning the war.

On July 2, 1878, the newspaper Bulgarian published a article that expressed the dissatisfaction with the Powers' manipulating the fate of Bulgaria, meanwhile put pressure on Russia for his hesitation to seize Constantinople:

Who could we believe? Sources from Constantinople inform that due to some telegrams between Emperor Alexander and the Sultan, the Russians will not enter into Constantinople; on the other side, from Petersburg sources say that the Russian politics will consider the British attitude. From Constantinople telegraphed that the peace negotiations have begun in Edirne, but meanwhile, one telegraph in London refuted this, saying that negotiations were interrupted by the entry of the British fleet in the Bosphorus. From the different opinions hold by Constantinople and London we should have idea to what extent the intercommunications between these two friendly kingdoms are true ... The first disagreement between them is what Russia will obtain in his wars. We consider these disagreements something more than the occupancy and rule of Constantinople.

We have said many times that there will be no peace before the Russians enter Constantinople, and this is happening. Now we speak the same opinion again and we make the following conclusion: today's situation cannot keep going for a long time; Russians no doubt will capture Constantinople; the Sultan will be forced to give what 
he wants and British fleet will stand inactively in front of a palace like today except for special circumstances, watching wrathfully the winners arranging everything according to their own wishes. ${ }^{26}$

Another page of the same issue wrote about the suspicion over Russia's sincerity to Bulgaria, though it seemed more like having confidence in the Russians.

Who would think that our greatest patron and liberator will be inclined to do harm both Bulgaria and her communication with Russia? No, the Emperor Alexander would never allow this happening, and it is unfair that we fear of and doubt his sincerity. The Russian autocrat came for liberating and uniting us, rather than dividing us. ${ }^{27}$

The same tone could be sounded in the issue of 11th this month, which refuted the rumours against Russia's attempt in Bulgaria: We Bulgarian people did not lose any spark of hope to our great father and liberator, on whom we rest our future." 28

Two tones could be sensed from the above passages: first, there were different voices in the Bulgarian society on the role played by Russia, and the mission of Russia in Bulgaria was being challenged; second, the mainstream of the population were willing to believe the sincerity of Russia for liberating Bulgaria. Furthermore, the Bulgarian elite intended to please, as well as put pressure on the Russian policy makers through their trust and compliments. The word father" represented one side of the Bulgarian public opinion, being grateful for the help of Russia with worshiping psychology close to cult; nevertheless, the Bulgarian nation is a Slavic nation equal to the Russian both politically and culturally. In spite of the big difference in population and the difficult state of Bulgaria, the father-son" relationship as mentioned in the latter passage would cause the fear of Bulgarian nationalists, even antipathy and vigilance against Russia. Later events proved this. 


\subsection{After the Russo-Turkish War}

The Treaty of San Stefano, signed at the end of the Russo-Turkish war in 1877-1878, played a vital role in the evolution of the Bulgarian nationalism. In 1878, the Russian army won the war with the Turks with the enthusiastic help of newly-established Bulgarian troop opulchenie. Obstructed by Britain, Russia made treaty at San Stefano with the Turks. The Treaty of San Stefano created the so-called Greater Bulgaria. According to Article VI of the Treaty, Bulgaria was constituted an autonomous tributary Principality, with a Christian Government and a national militia ${ }^{29}$. Its boundaries covered a vast land by the Danube in the north, the Black Sea in the east and the Aegean in the $\operatorname{south}^{30}$ (See Figure 2-2). Although Salonika $^{31}$ was reserved for the Greeks, the treaty maximally satisfied the desires of Bulgarian nationalists. On March 12, Slavonic Brotherhood, a Bulgarian newspaper approved the way of the territorial settlements in the Treaty of San Stefano:

The boundaries of Bulgaria outlined in the Truce of Odrina ${ }^{32}$ are reasonable. These boundaries are close to what the Treaty of San Stefano determines. The first point in the Truce says: Bulgaria shall be established as an autonomous Principality within the boundaries, where the majority of the population is Bulgarians. Its boundaries in no case can be less than what was adopted by the Constantinople Congress $^{33}$. She will pay tax, and will have national Christian Government and local militia. The Ottoman army will no longer be located there." 34

Meanwhile, the Bulgarians expressed their expectation and hope towards the life after regaining liberation. As early as the first day after the signing of the Treaty, that is, on March 4, Newspaper Bulgarian published an article talking about the expectations and demands to them: 
What would be required from us in this case? All of us, either elders or younger shall exert all strength to develop one activity unheard of, to gather all the people in one mind to support the managers in their effort because we can count on them and expect improvement. We suggest obedience with patience, which means not to sting in unfavorable situation, nor to incite hatred. We will be spectators of injustices that can be easily fixed in a quiet way. With these things we will adopt self-governance and will gain experience that we are somewhat lacking.

Let our brothers tirelessly and unitedly work together because there is no more sweet thing than to say: We are free." 35

The word such as - bedience", patience", -spectators", etc, demonstrated the compliant character of the Bulgarians, which reflected also the longing and appreciation for liberty. Meanwhile, the Bulgarian nationalism showed its defensiveness rather than offensiveness.

The Treaty of San Stefano satisfied both Bulgaria's territorial claims and Russia's ambition in the Balkans. Article VII through IX of the Treaty prescribed the supreme rights of Russia in Bulgaria:

The introduction of the new system into Bulgaria, and the superintendence of its working, will be entrusted for two years to an Imperial Russian Commissioner. At the expiration of the first year after the introduction of the new system, and if an understanding on this subject has been established between Russia, the Sublime Porte, and the Cabinets of Europe, they can, if it is necessary, associate Special Delegates with the Imperial Russian Commissioner.

The Ottoman army will no longer remain in Bulgaria... Russian troops will occupy the country, and will give armed assistance to the Commissioner if necessary. This occupation will also be limited to a term approximating two years.

The strength of the Russian army of occupation to be composed of six divisions of infantry and two of cavalry, which will remain in Bulgaria after the withdrawal of Turkey by the Imperial army, shall not exceed 50,000 men. ${ }^{36}$

On the surface, Bulgaria was given an unprecedented territory; but in fact, Russia was to have actual control over the San Stefano Bulgaria. Through the Treaty of San Stefano, Russia's century-old dream of expelling the Turks from the Balkans 
was on the verge of success - grasping the key to the Straits, which were significant for Russia's strategy in Europe as it sealed off the Straits area from the European continent.

When the newspapers published at the time in Bulgaria were reviewed, it can be seen that articles talking about Russia's vested interests in the Treaty of San Stefano were more often citations from media of the third country like Britain, instead of expressing directly the author's attitude. A short essay entitled The Mission of the Conference" in Bulgarian on March 8 said:

Post promulgated a long article saying that there are two substantive issues, on which the proxies will negotiate. One is how Constantinople would be protected after the Sultan remained as a shadow, when the boundaries of modern Bulgaria would be subject to Russian decision? Second, what plans should be made, so that dependence on Russia would not replace an occupied Bulgaria. ${ }^{37}$

Although the worries about the future fate of the state under Russia-dependency were rarely mentioned in public media, from the few examples we could speculate that the Bulgarians' attitude towards this issue was somewhat obscure, and they were trying to evade the embarrassing question. After all, compared to the miserable life under the Ottoman domination, liberation was overwhelmingly important. Given the situation, Tsar Alexander, as the initiator of the San Stefano Bulgaria, was praised into a divine power: - Fo celebrate our happiness, our Kingdom! Long live our great liberator, Tsar Alexander!"38

On the other hand, Bulgarian media were filled with indignation at the claims of the European Powers to modify the Treaty. An article entitled - Our Enemies are so many" published in Newspaper Slavonic Brotherhood on March 12, 1878 denounced: 
In the time of Ottoman rule, the Bulgarian people could not have other enemies except his own rulers who exploited them morally and materially. By now, however, liberated from this slavery, they obtained both freedom and many new enemies. Or more clearly, enemies of the Slavdom aimed their poisonous arrows at Bulgaria ...

Today the diplomacy ${ }^{39}$ rejected the wider boundaries of Bulgaria in comparison with Bulgaria's existing territory, and forbad the right of Russia to work further for organizing our liberated homeland; Russia's selfishness looked to find satisfaction in the limited consequences of the success of Russian military forces ... And to drag the general wills of European peoples to comply with her values and intentions, she took great care to uncover the unchanged and obvious cause of the latest war, and to endow the war with purpose and meaning that she had not endow in the beginning, i.e. panslavism and conquest. For this intention, she annoyed our brothers with same faith, Romania and Greece, to drag these neighbors of our state into general diplomacy. Under this circumstance, the military coalition around Russia would paralyze... There would be, as far as we can judge, policy of the Anglo-Hebrews in London. $^{40}$

The grudge against the Powers showed the desire of the Bulgarians for the Treaty. The reasons are obvious, that is, the Treaty of San Stefano maximally satisfied the territorial requests of the Bulgaria nationalists who cherished the dream of realizing Great Bulgaria. Some Bulgarian contemporary scholars believed that the Great Bulgaria proposed by the Treaty was reasonable because nearly $80 \%$ residents living in Macedonia and Eastern Trace were Bulgarians ethnically. Therefore, the Treaty of San Stefano not only conformed to the cultural and historical rights of the Bulgarian nation since ancient times, but was also in line with basic moral and political fairness ${ }^{41}$. The Treaty of San Stefano created a mythic Great Bulgaria, rather than a real one. Directed by this dream, for realizing the national long-cherished wish, the Bulgarian politicians and nationalists pushed the country into the abyss of war-disasters several times in the hundred years.

However, the Treaty offended almost all countries concerning the region, 
including not only the European powers such as Austria and Britain, but also the other Balkan states. The Great Powers, especially Britain, feared the overwhelming territorial and strategic advantages in the Balkans after its defeat on the Ottoman Turkey, which would affect their strategic interests in the Peninsula and the Aegean region. Austria-Hungary was disappointed with the treaty as it failed to expand its influence in Bosnia-Herzegovina ${ }^{42}$. Alarmed by the preliminary enlarged Bulgaria and Russia's actual control over it, the Great Powers called a meeting to discuss the revision of the Treaty. As a result, the Treaty was never implemented, and was superseded by the Treaty of Berlin.

Only three months after the signing of the Treaty of San Stefano, the European Powers gathered in Berlin, and held an important meeting known as Congress of Berlin. The most important task of the Congress was to decide the fate of the Principality of Bulgaria established in the Treaty of San Stefano, though Bulgaria itself was excluded from participation in the talks at Russian insistence ${ }^{43}$. The Macedonian lands were given back to the Ottomans, which removed Russia's obstacle to Austrian expansion southward. As a result, Bulgaria was deprived of access to the Aegean Sea, which was in the interest of Britain. The remaining Bulgarian territories were divided into two parts, Bulgaria and Eastern Rumelia. Bulgaria, being an autonomous principality, was to be ruled by a prince elected by the Bulgarians, but still under Russian advisory commission and military occupation for nine months. Eastern Rumelia, in contrast, was an Ottoman prince again, and its administration was to be supervised by a joint European commission ${ }^{44}$. 
After the Treaty of Berlin came out, the Bulgarian people began a new round of struggle for full liberation and unification of the state. Since then, the restoration of the integrity of the San Stefan Bulgaria and efforts for a unified and indivisible Bulgaria became the long-cherished national wish of the Bulgarian nation ${ }^{45}$.

In response to the signing of the Treaty of Berlin, Bulgarian media reacted intensively. In July 1878 , the newspapers consecutively published articles on their front pages, condemning the Powers, particularly Britain, for their manipulation of the fate of Bulgaria:

We announce with great discontentment that the result of the Treaty of Berlin is one of the most deplorable things, and that is a bad sign for the future peace of the Eastern, because even the whole Europe has been turned into a theatre stage, where only a few persons named Điplomats" played with passions... The Berlin Congress obviously was unforgivable and full of malice European carnage", with the British ax remained bloody in the Bulgarian body, the body beaten by Turkish whip. ${ }^{46}$

The press was also dissatisfied with Russia's stance and actions in the Congress of Berlin, with the consistent way of expression:

Everyone who has followed the course of the Congress was shocked by the hurried decisions and concessions the Russian representatives made in favor of the British caprices... Some say that Russia made concessions because he is aware of his weakening in the latest war, and because he simply was afraid of Britain; others believe that this is a consequence of Russia's hostility to our liberty. It is true that Russia made heavy losses and a second war would be ruinous for him. They guess as well that Russia has a fear for Britain, which is funny because they themselves who say this do not believe their own words. On the other hand, we do not deny that the Russian diplomacy is more or less opposed to making unworthy losses for us, but the diplomacy is not so feeble-minded that it cannot understand that making such big concessions for the benefits of the UK is not in the interest of Russia. The Russian representatives made this decision, nothing more than to prove to Europe and the world that the undertaking of the Treaty of San Stefano is impartial, and any other treaty, whether the Berlin or not, would stay below the San Stefano in any regard.

Who can tell us to what extent the Treaty of Berlin will succeed and how healthy its foundations will be? Who can convince us that after five or ten years the 
Bulgarians will not take Dobrudja from Romania? Who can deny that after twenty years at most, Roumelian Bulgaria will reach out hands to her sister and fight against Turkey?

Yes, these and many other things will become true even before the Berlin Treaty is put into action. Therefore, perhaps the day will come when Russia can speak openly to his enemies and rivals: "My undertaking is made jointly and practically. Admit your fault!",47

The fate of Dobrudja as mentioned in this article experienced repeated repartitions and distributions after 1878. In 1923, the Bulgarian nationalists established a special organization named the "Internal Dobrudja Revolutionary Organization" to fight against the Romanian administration. The movement of regaining Dobrudja under the Romanian domination was regarded in Bulgaria as a liberation movement, although it was considered by the Romanian authorities as terrorism. The fate of Dobrudja will be discussed in-depth in the chapter for clarifying the endevours of the Bulgarian nationalists made in the course of regaining the region as a whole.

As for Rumelian Bulgarian, i.e. Eastern Rumelia, the Bulgarian nationalists struggled even more actively, and the movement was called the Unification of Bulgaria. Supported by the Bulgarian Knyaz Alexander I, the Bulgarian Secret Central Revolutionary Committee was actively popularizing the idea of unification by means of the press and public demonstrations in the year of 1884-1885. In the autumn of 1885, the Unification of Eastern Rumelia with the Principality Bulgaria was accomplished. The Bulgarians feel proud of this even today. and on September 6 each year, the Bulgarian people celebrate the Day of Unification. The issue of Dobrudja also will be discussed further in a special part of the main body with the 
help of the sources from press and public demonstrations.

The signing of the two treaties after Russo-Turkish War 1877-1878 - the Treaty of San Stefano and the Treaty of Berlin, was a turning point for Bulgaria and the Balkans. The Treaty of San Stefano showed a unilateral scheme of distributing the Turkish territory in the Balkans, which intensified the existent contradiction between Balkan states. Although by signing it, Russia had nothing more than aiming at a temporary rough draft to enable a final settlement with other Great Powers, the Bulgarians almost immediately regarded it as the central point of their foreign policy, leading to the disastrous Second Balkan War and Bulgaria's even more disastrous participation in WWI. In other words, the treaty offered Bulgaria a glorious dream and harsh reality. Hence, the day of signing the Treaty - March 3, has always been celebrated by the Bulgarians as a holiday. In 1990, with the decision of the Bulgarian parliament, the date was declared a national holiday. These acts showed the longing of the Bulgarian nationalists for a big Bulgaria, or the said San Stefan Bulgaria, from which the outline of the Myth of Bulgarian nationalism could be sketched out.

The Treaty of Berlin, however, intensified the national sentiments of the Bulgarians and other Balkan peoples. It satisfied the European Powers' purpose to weaken the influence of Russia in the Balkans, while changing the balance of power among the Balkan states. The partition of the Ottoman territories in the Balkans made the history of Balkan national egoism, a national egoism based on the consequences of the Balkan peninsula being divided by the Powers into their spheres of influence ${ }^{48}$. Many scholars specializing on the Balkans believe that the national problems were 
highlighted exactly from 1878. Prior to this, no one had called Balkan the powder keg of Europe", a phrase that became popular right after the Treaty of Berlin.

Finally, it should be noted that the Bulgarian press of the time rarely made lengthy complaint about either Turkish atrocities or authoritarian rule. On this matter, the first issue of Bulgarian Journal made a convincing explanation that they turned their attentions instead to the irregularities and criminal activities of the members of the [Ottoman] administration, be they cleric or secular men; most of our newspaper will have the goal of showing the people how to become conscious of their civic, state, church, and national rights; to show its means by which various evils can be avoided; ..."49 The text explained that this -rgan”, Bulgarian newspapers, would serve the tasks to this end since it would not be dependent on the whims of those who were loyal to the ruler.

\footnotetext{
1 Confessional communities in the Ottoman Empire. After Tanzimat reforms (1839-1876), the term was used for legally protected religious minority groups, similar to the way other countries use the word nation.

The millet system of Islamic law has been called an early example of pre-modern religious pluralism.

${ }_{2}^{2}$ Mari A. Firkatian: The Forest Traveler: Georgi Stoikov Rakovski and Bulgarian Nationalism, New York: Peter Lang, 1996, p. 8.

3 Danube Swan, September 22, 1861.

4 The Cretan Revolt (1866-1869) was an uprising against Ottoman rule, the third and largest in a series of Cretan revolts between the end of the Greek War of Independence in 1830 and the establishment of the independent Cretan State in 1898.

${ }^{5}$ Cited in The History of Bulgaria, vol. II, p. 447.

6 Nationality, June 1, 1869.

7 Ibid, June 8, 1869.

8 Ibid.

9 Nationality, June 31, 1869.

10 Bulgarian, July 16, 1878.

11 Agha, as a title for a civilian or military officer, was placed after the name of certain military functionaries in the Ottoman Empire.

12 Cited in The History of Bulgaria, Vol. II.

13 Liberty, August 5, 1872.

14 Hatti humayun is the dipomatics term for a document or handwritten note of an official nature composed by an Ottoman sultan.
} 
15 Danube Swan, September 13, 1861.

${ }^{16}$ Refers to Europe.

${ }^{17}$ Danube Swan, October 10, 1861.

${ }^{18}$ Liberty, August 5, 1872.

19 Liberty, July 1, 1871.

${ }^{20}$ Independence, October 5, 1874.

${ }^{21}$ Liberty, July 21, 1872.

22 Ibid.

${ }^{23}$ Independence, February 4, 1873.

${ }^{24}$ A Bulgarian revolutionary organisation founded in 1869 among the Bulgarian emigrant circles in Romania.

${ }^{25}$ Ivan Lazarov et al.: Short History of the Bulgarian Nation. Sofia: National Education, 1993, p.176.

${ }^{26}$ Bulgarian, July 2, 1878.

${ }^{27}$ Ibid.

${ }^{28}$ Bulgarian, July $11,1878$.

29 Thomas Erskine Holland: The European concert in the Eastern question: A Collection of Treaties and other Public Acts, The Clarendon Press, 1885, p. 338.

${ }^{30}$ See The Preliminary Treaty of Peace, signed at San Stefano, cited in The European concert in the Eastern question: A Collection of Treaties and other Public Acts, The Clarendon Press, 1885, 335-348.

31 Now the city is known as Thessalonica, the second-largest city in Greece. In 1235, Bulgarian Tsar Ivan Asen II vanquished Epirus, and therefore the city became the vassal territory of Bulgaria. After the death of Tsar Ivan Asen II, Bulgarian state weakened and in 1246, the city was annexed in the Empire of Nicaea. In this city were born Saints Cyril and Methodius, two brothers who devised the Glagolitic alphabet, used by Bulgarians and majority Slavs. Mainly for this reason, the Bulgarians admired to regain Salonika to achieve a kind of national dream.

32 Signed on January 19-31, 1878 between Russia and the Ottoman Turkey for ending the military activities in Russo-Turkish war (1877-1878).

33 Constantinople Conference (1876-1877) of the Great Powers was held in Constantinople (Istanbul) from December 1876 until January 1877. The Conference agreed on a substantial autonomy to take the form of two new Ottoman provinces established for the purpose: Eastern, with capital Tarnova, and Western, with capital Sofia. (-Correspondence respecting the Conference at Constantinople and the affairs of Turkey: 1876-1877”, Parliamentary Papers No 2, 1877, p. 340.)

${ }_{34}^{34}$ Slavonic Brotherhood, March 12, 1878.

${ }^{35}$ Bulgarian, March 4, 1876.

36 Thomas Erskine Holland: The European concert in the Eastern question: A Collection of Treaties and other Public Acts, 1885, p. 339-340.

${ }^{37}$ Bulgarian, March 8, 1878.

38 Ibid, March 4, 1878.

39 Here the diplomacy" refers to the diplomatic activities conducted by the European Powers surrounding the revision of the Treaty of San Stefano.

40 Slavonic Brotherhood, March 12, 1878.

${ }^{41}$ I. Bodjilov: History of Bulgaria, 1993, p. 403-404.

${ }^{42}$ For details, refer to The European concert in the Eastern question: A Collection of Treaties and other Public Acts, The Clarendon Press, 1885, 335-348.

${ }^{43}$ Stephen D. Krasner: Sovereignty: Organized Hypocrisy. Princeton University Press, 1999, p. 165.

${ }^{44}$ See Select Treaties and Documents to Illustrate the Development of the Modern European States-System, Oxford: Oxford University Press, 1915, 79-83.

${ }^{45}$ Scientific Centre for Bulgarian National Strategy: Bulgaria in the 21th Century-Bulgarian National Doctrine. Vol. I. Sofia, 1997, p. 75.

${ }_{46}^{46}$ Bulgarian, July 2, 1878.

${ }^{47}$ Ibid, July 6,1878 .

${ }^{48}$ Cited in Ma Xipu, The History of Bulgaria, 2011, p. 107.

${ }^{49}$ Bulgarian Journal, No. 1, June 26, 1857. 


\section{CHAPTER 4 LANGUAGE AS A STIMULUS FOR}

\section{BULGARIAN NATIONALISM}

Language is a central feature of human identity. When we hear someone speak, we immediately make guesses about gender, education level, age, profession, and place of origin. Beyond this individual matter, a language is a powerful symbol of national and ethnic identity ${ }^{1}$.

We have to admit that the national strategies of a state, along with its foreign policy are easily to be modified by the likes and dislikes of policymakers. In contrast to this, however, the evolution of language shows us relatively static data of the development of a nation because it basically does not change with the wishes of certain individual or minority. Thus we may state that the slow evolution of language tells us the inherent psychology trends of a nation.

If someone asks the question what is language, the answer which naturally comes to our mind would be: language is a tool for communication, or a way of self-expression. This represents the elementary functions of language, while the role of language is by no means limited to this. Wilhelm von Humboldt defined language by stressing its subjective feature: Eanguage is, as it were, the external manifestation of the minds of people. Their language is their soul, and their soul is their language"2 Given the definition of Humboldt, can we develop this statement in a broad sense: national language is the soul of a nation, and the soul of the nation is national language? 
Many intellectuals have given explicit answers to this inference. The theory of ethnic nationalism as it was developed by Herder held that humanity was divided into national groups, and that these nations were differentiated in profound ways and that their distinctiveness dated from the beginning of time. Each culture was moulded by the particular experience of the group. The language spoken by the group caused it to conceptualize the world in a certain way that was different from speakers of other languages. Ethnic nationalists thus believed that nations are a natural phenomenon whose linguistic and cultural cohesion are derived from a common past and whose destiny is to be a single political unit ${ }^{3}$.

In much the same as Spolsky's doctrine mentioned above, Brass presented the concept of a pool of symbols" that expresses the internal values of a community or a people, as a tool for mobilization or nationality-formation. He called the nationalist movements the striving to achieve multi-symbol congruence among a group of people defined initially in terms of a single criterion."4 The symbols are mainly linguistic and religious. In the process of nationality-formation, or myth construction" in a struggle against opponents, he argued, values are affixed to symbols of language or religious identity, depending on the social reality of that community. Further, since the linguistic, religious, historical, and cultural traits of a nation or community may be employed as symbols, a full-blown and coherent myth may ultimately develop" to promote a sense of nationalism ${ }^{5}$.

Known as an English historian, Sir Lewis Bernstein Namier (1888-1960) supported national self-determination during WWI, which was based on the 
assumption that national autonomy or independence would lead to fairer social order. Namier contended that the nationalisms that entered the political arena in 1848 and lasted during the next one hundred years were primarily linguistic ${ }^{6} . \mathrm{He}$ advocated that the German nationality is linguistic and racial', rather than political and territorial. It finds its final expression in the doctrine of the Volksdeutsche which claims that anyone of the German race and language owes allegiance, first and foremost, to his German Fatherland ${ }^{7}$. For the countless ties to the Central and Eastern Europe, his doctrine on the relations between language and nationalism exerted significant influence upon varying degrees the Balkan nationalism. In this region, before national independence the nations were usually defined by the national languages; after the foundation of the nation-states ${ }^{8}$, languages were used to enhance national unity and solidarity ${ }^{9}$.

George W. White tried another way of investigation, comparing between Western European nationalism and nationalism in Central and Eastern Europe in the categories of Enlightenment and Romanticism. White characterized nationalism in Western Europe as the nationalist ideal in the context of Enlightenment philosophy, which stresses rationalism and individual rights. By reordering political control over territories to create a number of small states, nationalism in Western European helped to ensure the rights of individuals and redefined imperial territories as national ones. Nationalism in Central and Eastern Europe, in contrast, was attributed to the scope of Romanticism, which implied the redrawing of boundaries according to the distribution of nations, supposedly defined by language and religion"10 ${ }^{\text {. Romantics, }}$ 
according to White, promoted the use of native, vernacular languages, a sharp contrast to Enlightenment philosophy, which valued universal languages of Latin and Greek. For nationalism in Central and Eastern Europe, he pointed out, Romanticism represents a different spatial ordering, i.e. nationalists defined the national territory on the basis of the spatial distribution of language speakers. He believed that the South Slavic nations, including Serbs and Bulgarians, used language and religion to define their respective national identities and not vice versa ${ }^{11}$. Prior to the rise of nationalism, language use and religious affiliation were not so significant to the formation of identity among the peoples of the Balkans. With the rise of nationalism, however, separate and distinct languages began to grow and develop with the respective political organization of space. On the basis of that, modern languages were codified and cultivated in a similar manner as the states respectively came into being. However, languages, as means of mapping out the spatial distribution of nations, had limitations because many individuals did not actually speak their true national languages due to complex historical reasons. Also due to this, the national identity of the Balkans has been intertwined with language issues, creating an inextricable situation.

The academic discourses have clarified the relations between language and nations, as well as why language can be used for constructing national identity and nationalism. But if we come to the case of Bulgaria, we have to trace back to the beginning of the Bulgarian National Revival to explore the pragmatic approach.

\subsection{To eliminate the effects of the Greek language}


Specific objectives characterized the national revival period in the Balkan Peninsula and independence from Ottoman domination was the ultimate goal. For the Bulgarians, the insistence on using Bulgarian as their only language of communication and the schooling of the population in their own tongue was of enormous importance ${ }^{12}$.

The Cyrillic script was developed in the First Bulgarian Empire during the $10^{\text {th }}$ century at the Preslav Literary School ${ }^{13}$ because Boris I of Bulgaria desired Bulgarians to have their own writing system. Since then, the Saints Cyril and Methodius and their disciples were dedicated to translating the Bible and other Ancient Greek ecclesiastical texts into Old Church Slavonic ${ }^{14}$ for the Christianisation of the Slavic peoples ${ }^{15}$.

After the fall of Constantinople to the Ottomans in 1543, Bulgaria ceased to exist as an independent country, so did the Bulgarian Orthodox Church. The vast majority of Church leaders were executed, and then it was fully under the ecclesiastical jurisdiction of the Patriarch of Constantinople restored by the conquering Islamic Ottoman ruler, Sultan Mehmed II, who wished to establish his dynasty as the direct and legitimate heirs of the Eastern Roman Emperors. The Patriarch implemented the Millet ${ }^{16}$ system, which granted a number of civil and judicial functions to the Patriarch of Constantinople. At the beginning of the Ottoman rule, the higher Bulgarian church clerics were replaced by Greeks, and thus the Bulgarian population was under dvojnoto robstvo, double yoke - political by the Ottomans and cultural by the Greek clergy ${ }^{17}$. Since then, the Old Bulgarian language also ceased to be the language of public life and official literature, and its use in liturgy was limited and replaced by Greek. At the end of the 18th and the 
beginning of the 19th century, the clergy of Constantinople Patriarch opened numerous schools with all-round Greek language curriculum and nearly banned the Bulgarian liturgy.

The influence of Greek language was not limited merely to the churches - it spread into the commercial and educational sphere as well. In the Bulgarian society at the time, speakers and writers of Greek were identified with high social recognition and prestige because they were well-educated. A quote from Marcia MacDermott's History of Bulgaria, 1393-1885 shows this picture:

Greek cell schools ${ }^{18}$ had long existed all over Bulgaria wherever there were Greek colonies. These schools were not much different from the Bulgarian cell schools, but they were dangerous centers of Greek influence in Bulgaria, because of the economic advantages of knowing Greek, which was the lingua franca of trade in the Balkans, and because of the misplaced snobbishness of certain wealthy Bulgars who considered it eultured" and -educated" to speak Greek and live like Greeks. ${ }^{19}$

Putting the comment on Greek influence in Bulgaria aside, the quote from MacDermott reflects the fact that knowing Greek became synonymous with dignity, wealth, literacy and privilege in Bulgarian society. That is why Borislav Borisov refers to the Greek language before the Bulgarian national revival as the tanguage of the cultural invader" 20 , meaning that the Bulgarian nation was facing the danger of linguistic assimilation by Greek. Under the circumstance, the major issue for the national enlighteners at the beginning of the National Revival was to protect the rights of using the Bulgarian language, to indicate the needs of speaking, reading and learning their mother tongue to the Bulgarians ${ }^{21}$.

The Bulgarian enlighteners tried to use language as their weapon to fight Greek 
and get rid of its influences. Thus they called for the opening of schools in Bulgarian and the struggle for an autonomous Bulgarian church. As a national revival occurred during the $19^{\text {th }}$ century, a modern Bulgarian literary language gradually emerged. It drew greatly on Church Slavonic Bulgarian and to some extent on literary Russian.

Paisii Hilendarski articulated in what has become code-text for Bulgarian nationalism - Slavonic-Bulgarian History, stimulated the Bulgarians to prize their own history and learn the Bulgarian language:

There are those who do not care to know about their own Bulgarian people and turn to foreign ways and foreign tongue; and they do not care for their own Bulgarian language but learn to read and speak Greek and are ashamed to call themselves Bulgarians. O, you senseless fool! Why are you ashamed to call yourself Bulgarian and do not read and speak your own language? Or had the Bulgarians no kingdom and state? ... In the entire Slavic race the Bulgarians have had the greatest glory, they first called themselves tsars, they first had a patriarch, they first became Christians, and they ruled over the largest territory... Here, you say, the Greeks are wiser and more cultivated, and the Bulgarians are simple and stupid, and have no refined speech; therefore, it is better to become part of the Greeks. But look, you senseless, there are many more people wiser and more glorious than the Greeks. Has any Greek abandoned his tongue and learning and people? ... You, Bulgarian, do not be fooled, but know your people and language, and learn your language! ${ }^{22}$

This quotation more or less signifies the purpose of the author who spoke about the danger of Bulgarians falling victim to the Hellenization policies of the Greek clergy.

Analysing from the title of this work (Slavonic-Bulgarian History, another translation is The History of Slavonic-Bulgarian), the view of Hilendarski to identify the Bulgarians as part of Slavs was clear. As mentioned in the Preface, the Bulgarians descended mainly from the three tribal groups (Thracians, Slavs and Bulgars). From the Thracians (the local residents during the Roman rule) certain cultural elements 
were taken ${ }^{23}$. From the Bulgars the ethnogenesis and the early statehood were inherited (with the establishment of the First Bulgarian state led by Khan Asparukh). The Slavs $^{24}$ who arrived in the Balkans during and after their southward expansion towards the Balkans during the 7 th-8th century, gradually outnumbered and assimilated the residents living in the present-day Bulgaria by their culture and language ${ }^{25}$. This identification partly stemmed from the language spoken by the local residents, and also became an instrument of the people to distinguish Self from Others.

The text of Slavonic-Bulgarian History was an enlightening address to all Bulgarians, not only the literate, but also the illiterate who could only listen to the text read aloud by others ${ }^{26}$. In the $18^{\text {th }}$ century, when there was no Bulgarian national written language for expressing the concepts and ideas different from traditional way of thinking, writing in simple language for the mass was still difficult. In spite of this, Hilendarski made it possible based on Damaskin ${ }^{27}$ literature and Church Slavonic language, thus began the secularization of the Bulgarian literature.

Hilendarski was the first modern Bulgarian scholar who consciously raised the notion that language serves as an expression of national consiousness ${ }^{28}$. Without departing substantially from the commonly used Damaskin and Church Slavonic language, he advocated that the nature of the literary language was to be simplified for common Bulgarians. This idea of Hilendarski summarized the trends of socio-economic development in Bulgarian lands at the time, and therefore should be regarded as the first clear sign of the national revival and of the historical and cultural 
process from the late 18 th century.

Many scholars like B. Tsonev ${ }^{29}$ believed that Hilendarski and his History exerted influence largely in the ideological perspective, pushing the national processes forward. In the sphere of language, however, his contribution was that he encouraged the Bulgarians to read and write in their own laguage rather than in Greek, a deed with instructive meaning. Meanwhile, along with the other leading figures of the early Bulgarian National Revival (Sophronii Vrachanski ${ }^{30}$, Yoakim Karchovski ${ }^{31}$, Kiril Peychinovich ${ }^{32}$ ), Hilendarski indicated a right road for the construction of the Bulgarian language, which was characterized by maintaining the literary tradition, limiting the literary features in quantitative and functional terms in favor of the characteristics of folk speech, normalizing the language of literature and limiting the use of orientalist words in the literary language ${ }^{33}$.

\subsection{Dialects versus Church Slavonic}

The Bulgarian literary language went through a long and bumpy path of development and construction after Paisii Hilendarski. In the first stage ${ }^{34}$ of this course, the debate was basically focused on the relationship between the language features of Church Slavonic (written, traditional) and dialects ${ }^{35}$ (vernacular, spoken), in practice, namely to establish the criterion of the modern literary language.

It is necessary to explain these two concepts here. Church Slavonic originated as a literate language when the missionary Cyril devised an alphabet for the spoken language of the Slavs in Great Moravia in the 9th century. Cyril and Methodius used 
the alphabet to translate liturgical books when preaching Orthodox Christianity to the Slavs of Moravia. The original form was called Glagolitic, which was later refined into the Cyrillic alphabet by the disciples of the two brothers.

The spoken Bulgarian was mainly split into two broad dialect areas, whose divergence occurred at some point during the Middle Ages. They were Western dialects, which was called frard speech" in terms of pronunciation, and Eastern dialects with soft sounds.

With the development of a national educational movement in the second quarter of the 19th century, three literary schools emerged with efforts to explain theoretically the language practice of the time: the Modern Bulgarian school based on the vernacular, with proponents Peter Beron, Ivan Bogorov and Vasil Aprilov; the Slavonic-Bulgarian school stressing on the medieval linguistic legacy, represented by Neofit Rilski; and the Church Slavonic school emphazing the language used by the Church and advocated by Khristaki Pavlovich, Constantine Fotinov and others. ${ }^{36}$ Each of the three schools could not completely exclude the influence of Church Slavonic in the construction of the modern literary language. The difference between them was that they adopted it in various degree and forms.

Supporters of Church Slavonic school took the tradition position, trying to put Church Slavonic at the heart of Bulgarian. They insisted on preserving not only the vocabulary, but also the phonetic and morphological features of the language in the Bulgarian literary practice. For Fotinov, the language in Church Slavonic books was the language of Cyril and Methodius, and of the old Bulgarians. The principle of the 
school was explicit, that was, to respect and keep the Bulgarian literary heritage. Furthermore, from utilitarian and practical perspective, they had seen in Church Slavonic (they often called it - $९$ ld Bulgarian") the readiness for being constructed and stylistic richness, which would not encroach on the time and energy of the reviving Bulgarian nation when it sought new linguistic resources ${ }^{37}$.

The Modern Bulgarian school held the opposing view. Its most prominent representative Peter Beron was the first to develop the major principle of the Bulgarian language stated by Hilendarski (but unfulfilled due to historical difficulties at dawn of the Bulgarian literay language $)^{38}$. If the founder of the modern literary language was Hilendarski and his work Slavonic-Bulgarian History, Fish Primer ${ }^{39}$ (1824) by Peter Beron, was the first work written entirely or predominantly in Bulgarian vernacular, a language with few Slavonic elements ${ }^{40}$. With the Bulgarian vernacular language character, Fish Primer opened a new page in the history of the Bulgarian language, paving a broader path for the construction of modern Bulgarian. On the basis of this language conception, the first grammar of Bulgarian language was accomplished by Ivan Bogorov in $1844^{41}$.

The Modern Bulgarian school recognized the place of the vernacular in terms of grammatical system, pronunciation and vocabulary, meanwhile enriched the literary language with an abundance of Slavonic and Russian sources. Representatives of this school diligently defended the people's right to write in speakable language". Therefore, after the publication of Fish Primer, the most significant feature of the Bulgarian literary language in the second quarter of the $19^{\text {th }}$ century was the 
emergence of a large number of spoken (dialectal) elements and characteristics in it. Although these elements were mostly stiff in written form, the character of the literary language was significantly transformed in favor of the people's speaking and reading. Church Slavonic forms, words and graphics were retained for long in literary practice, but in the second half of the $19^{\text {th }}$ century, they were proved to be bleak even for the most ardent defenders. Gradually, the example of Beron and his Primer attracted more followers, supporting his thesis on the criterion of the literary language.

The school of Slavonic Bulgarian was often described as a compromise, a result of the struggle between the first two schools. The leader of this school was Neofit Rilski who made the first popular translation of the Bible entirely in the modern Bulgarian language (not a mixture between Church Slavonic and vernacular elements) ${ }^{42}$. Theoretical views of this school were elucidated in the lengthy Philological forenotice" of Neofit's Bulgarian Grammar (1835), in which Neofit established his conception of the Bulgarian literay language, or more precisely, the national character of the literary language. The starting point of this conception was also based on the Bulgarian vernacular, the same as that of the Modern Bulgarian school, which showed a consensus among the majority of the Bulgarian public on the nature of the modern Bulgarian language. Differences between the two schools were the ways they suggested to build the literary language. Supporters of the Modern Bulgarian school were satisfied with the declaration that literary language should follow the language of the people (most often refering to their own native speaking); 
Slavonic Bulgarian aimed to offer a concrete way of the language construction. Its contribution was primarily in promoting the idea of a nationwide criterion of the literary language, which would be achieved after removing or overcoming the differences between dialects. Neofit and his adherents offered to take into account all lexical, phonetic and gramatical features of the Bulgarian spoken language common to all Bulgarian dialects. In the case that the oneness of speakings was unachievable, it would be found in Old Bulgarian (i.e. Church Slavonic) ${ }^{43}$ language. Given this, the idea of this school was actually a variety of the Bulgarian (or modern Bulgarian) language, because it accepted the living Bulgarian and its literary basis, giving secondary role (function) to Church Slavonic. Admittedly, the Slavonic Bulgarian school broadened the horizon of the modern view of Bulgarian literay language in general.

By the middle of the 19th century, the Modern Bulgarian school acquired an unconditional preponderance after a long struggle between the three literary schools. The outcome was the most democratic solution - the legitimization of the vernacular. This can be explained by the major influence of the merchant and artisan circles in organizing the modern Bulgarian educational network, as well as by the strong interest in folklore, especially intensive during the 1840 s, and it was influenced by developments both in Germany and in Russia. ${ }^{44}$

The fixed criterion of the literary language based on the vernacular adapted to the needs of the then constructed awareness for the nationwide spiritual and political unity; in return, it served as a booster of national consciousness. The then existing 
vernacular, however, did not satisfy the demand for unity. Given that, what followed was another important question - the overcoming of the dialectal differences. The increasingly strengthened needs for a uniformed national language and the polymorphic nature of the literary language stimulated the spiritual potential of the nation to solve this contradiction by creating conditions and prerequisites for overcoming the polymorph. The transformation of the Bulgarian literary language in the third quarter of the 19th century left a crucial mark - Extralinguistic context that lacked an independent Bulgarian state with authoritative administrative and cultural center, which was able to organize, guide and lead the establishment of a national literary language. The absence of such a center in turn motivated discussion and democracy in the struggle to choose the basis dialect, and that either literaries or publicists were given complete freedom to discuss publicly any proposal on this important linguistic issue. In fact such democracy in linguistic discussion started early in the second quarter of the 19th century, when the basis of the criterion of literary language was being discussed. In Philological Forenotice" of Bulgarian Grammar in 1835, Rilski argued that the best way to resolve the dispute and the unanswered questions of the language reformation was to expose all perceptions and proposals to public discussions ${ }^{45}$.

There was a heated debate on the choice of the basis dialect in the Bulgarian press during the 1850-1870s. Roughly speaking, two major viewpoints emerged: first, the creation of the Bulgarian literary language be on a polydialectal basis, i.e. the formation of a common language that would include characteristics of all possible 
dialects; and second, which was shared by the greater part of the contemporary literary figures, the creation of the Bulgarian literary language be on a monodialectal basis $^{46}$.

Which dialect would conform best to the future literary Bulgarian? A general consensus in answering this question came down to the purity of the language as the main criterion. All national figures connected this question with the national character of the literary language and the consolidation of the Bulgarian nation.

\subsection{From language purity to purism}

The use of loanwords is usually a natural phenomenon in the life of a language, and likewise, no people live in isolation from other nations and develop their culture only based on its traditions. Cultural interaction between peoples is expressed in the mutual relationship between their languages.

The penetration of foreign words in a language may happen under various circumstances: 1 . In the cultural and economic interaction between nations without territorial mixing. In this case, the borrowing of words happens mainly in a literary way and partly through persons who have mastered the language of the corresponding nation. Loanwords usually first penetrate the speech of the intelligentsia, and then spread more widely. Uncritical imitation and low cognition to native language are the main reasons for the spread of loanwords. 2. In language contact of the population (of two nationalities) with spatial mixing. In this case, bilingualism within the community would be inevitable, particularly in popular 
speech. In literary language, however, only a fraction of foreign words remain.

Coming to the Bulgarian case, one of the key issues in the development of the Bulgarian national language was the question of proper treatment of foreign elements in it. The notion of language purity was very popular in the Bulgarian public world of the time. Language purity was based on the idea that the dialectal diversity was a result of an aberration, i.e. the development of Bulgarians and the Bulgarian culture under a double repressive influence: the Turkish and the Greek ${ }^{47}$. The Bulgarian dialects were influenced by Turkish, which was the official language of the Ottoman Empire, in the form of the Ottoman Turkish language, mostly lexically. Many of the numerous loanwords from Turkish (and from Arabian and Persian via Turkish) were adopted into Bulgarian during the long period of Ottoman rule.

What did purity mean for the then existing Bulgarian after the five-century foreign rule? It was perceived by all as the lack of foreign words and other linguistic elements (mainly Turkish and Greek) in the language ${ }^{48}$. But the question of language purity was normally associated with the literary language. In a broader sense, the struggle for purity of language also covered the fight against the use of slangs.

It was a natural choice for the Bulgarians that the language should fight against foreign elements when they were unnecessary by nature, and when foreign elements were many enough to interfere with the healthy development of the language, and to twist the national identity and dignity of the people. Hence, the preservation of the Bulgarian-language-in-the-making from interference of foreign elements became an important public issue of Bulgaria, for which the educators and linguists in the third 
quarter of the 19th century made great efforts. Generally, many of the loanwords from Turkish and other Balkan languages were replaced by the native terms, while the words inheritated from the Church Slavonic (and to some extent literary Russian, which had preserved many lexical items from Church Slavonic) remained in the Bulgarian. This also represented a key point in the principles of forming the Modern Bulgarian literary language, that is, to purify the language by replacing Turkish and Greek loanwords with words from the vernacular and from Church Slavonic ${ }^{49}$. By mid-century the Church Slavonic as a lexical pool gave way to Russia, which exerted the strongest lexical influence in the immediate pre- and post-liberation period ${ }^{50}$.

In this course, the loanwords were roughly divided into two types: one that contributed (or had contributed) to the enrichment of language and were embedded (or would be possibly deployed in the future) in nationwide or professional practice; others were those that were useless and even harmful to constructing the language (as they had their very accurate matches in native language), as well as those hard to be absorbed by the broader community. The first type of foreign words were called zaemki (borrowing words), and the second - chuzhdici (foreign words). For instance, words from foreign origin such as physics, philosophy, mathematics, grammar, materialism, socialism, communism, constitution, democracy, Republic, university, Minister, party and many others, were cultural borrowings in Bulgarian, against which it was pointless and unjustified to fight ${ }^{51}$. Of course, the exact distinction between borrowings and foreigns in many cases was difficult to make. The struggle for the 
purity of the national language was against the use and penetration of useless elements of foreign origins. When this fight had the character of an organized movement, it was called purism".

Many writers and public figures of the time believed that the peasant language, among all others, was less contaminated with loanwords. Among them, Vasil Aprilov, a prominent representative of the Modern Bulgarian school, was one of the most steadfast advocators. He argued, In my opinion, our language would be spoken in a purer form, where it is less mixed with other languages. By the way, it is purer in the villages than in the towns because the former are inhabited only by Bulgarians, whereas the latter have Ottomans and Greeks." ${ }^{, 52}$

In the struggle to preserve the purity of Bulgarian during the National Revival, Ivan Bogorov was the greatest defender. Although his notion was extreme to a certain degree, he had significant contributions to preserving the national character of Bulgarian language before the liberation and a few years after that ${ }^{53}$. He dedicated his whole life to the formation and development of the native language, regarding it as a key driver for the construction and rise of the Bulgarian people as a nation ${ }^{54}$.

Bogorov accurately realized the importance of mother tongue in the cause of national revival. Therefore, he endeavored to implement his ideal to -stand firmly by their language and their faith", for which he called to all his fellow countrymen in the first issue of newspaper Bulgarian Eagle ${ }^{55}$ (1846). And then he elaborated his idea in Tsarigradski Newspaper $^{56}$ that the concerns with language was the most significant cause for the mental and moral development of the Bulgarian nation ${ }^{57}$. Bogorov owed 
his orientation to the dialects (or folk speech) to his perception that the people's needs for education were related with the basis of the literary language, because he believed that there was no shorter route to enlighten the people than the native language.

Early in his first articles - original and translated: General geography for children"(1843), First Bulgarian grammar"(1844) and newspapers which he wrote and edited, Bogorov stood by the positions of the Modern Bulgarian school, supporting the vernacular language to serve as the basis of the forming norms of the uniform literary language.

As a defender of linguistic purism, in his attempts to counter Greek and Russian influence on Bulgarian, Bogorov introduced a number of rare dialectal words and neologisms to the literary language. He fought for decades against the use of foreign words in the language, expecially against Greek and Russian words. In perceiving the features of the Bulgarian language, particularly in the phonetic form of many words, Bogorov went further than his predecessor and his contemporaries. He almost restored the Bulgarian accent (or Bulgarian phonetic form) of words, in which he replaced $\rightarrow-0$-" with pure Bulgarian form $\rightarrow-\mathbf{-}-"$. This principle was implemented in a number of words, for instance, дълг, мъж, мъка, Съд, Сън, тъкмо, whose original form had been долг, муж, мука, суд, сон, токмо, etc. In the same way he transformed Russian loanwords as создание, сообщение, состояние, восточен, состовлява, etc, which were Bulgarianized as съзнание, съобщение, състояние, въсточен, съставлява, etc. ${ }^{58}$ 
When he could not find the accurate and ideal expression in the vernacular, Bogorov created words by himself. In the first book he translated - Mathematical Geography (1842), he showed himself as a neologist on terminology. But this effort, from its beginning, damaged the route of moderate linguistic purism as a numbers of these words were unclear to readers ${ }^{59}$. In increasingly more cases, Bogorov was criticized, ironized and even isolated. Many of his neologisms were not accepted in the language because their original forms had been accepted by the users. In spite of this, a large number of words proposed by Bogorov made their way into the modern Bulgarian vocabulary. When we talk about the contributions of Bogorov as a builder of the Bulgarian literary language and advocate of the preservation of the national essence, it is necessary to bear in mind that his contributions should be looked in two directions:

- $\quad$ in the activities of Bogorov in constructing the literary language in the first half of the 19th century based on the vernacular and its further enrichment at different levels, and

in the fight for the prevention and reduction of already-formed literary language from foreign influences, particularly in the second half of the century.

Even though we pay more attention to his defence of the purity of Bulgarian in this dissertation, the common view about Bogorov and his contributions in Bulgarian linguistics is that the achievement of Bogorov in the first direction is of more significance for the area. In either case, however, his philological pursuits were 
absolutely clear that he devoted himself to the construction of a pure native language with as many as possible Bulgarian national features.

Alexander Teodorov-Balan was another linguist who engaged in purifying the Bulgarian language for more that seventy years. In many of his papers in various journals and newspapers, he pursued to clear up unnecessary foreign words in the Bulgarian literary language, and meanwhile, with the very language of his works, he showed how to carry out the struggle against influence of foreign languages. He enriched the language with dialectal words, at the meantime replacing loanwords by creating neologisms on the basis of his knowledge of the laws of word-building. In this sense, A. T.-Balan also went to extremes, which he recognized in his later years. In his speech at the meeting of his 95th anniversary, he avowed: In the recent decade, I saw my extremes and slowly denied them. But I did not reject my opinion, from which I established my specific language and syllable." ${ }^{60}$ It should be noted that he successfully introduced a few dozen words in the literary language, such as възглед (opinion), гледище (perspective), общувам (communicate), предимство (advantage), предходен (transitional), становище (attitude), украса (decoration), усет (sense), etc. A number of foreign words were replaced by the following words: религиовен (взгляд in Russian, religious), гледна точка (точка зрения in Russian, point of view), деятелност (activity), екскурзия (trip), курорт (resort), предшестваш (preceded) and so on. In many cases, we see perfectly Bulgarianized forms (replacements for Russian, Czech and Serbo-Croatian matches), using traditional Bulgarian words to express the new 
content (усет for instance), and so forth. Some phrases like въз основа на (on the basis of), съгласно с (according to), тъй че (so that), were also introduced by A. T.-Balan.

In the nationalist theory of Johann Gottlieb Fichte, national identity is seen as depending on the purity of a nation's language. When the Bulgarian language appeared as the soul of what was Bulgarian, any displacement of the line between the native and the adopted or foreign elements in the language would disturb the identity of the nation as well ${ }^{61}$. When Bulgaria was still in the stage of the awakening of national consciousness, language was a unifying factor that enabled the people to defend their cultural independence, and then achieving the national political ends. Since the construction of Bulgarian modern literary language happened in the national revival, the aspiration of linguistic purists for purifying their national language to-be appeared as a rational choice, with which they intended to highlight the national features. The struggle gradually grew into a real movement with a number of Bulgarianized words and neologisms entering practical use. Although the efforts of the purists were somewhat extreme, as a pulbic event, their struggle for the purity of the Bulgarian language always exhibited a sober moderation.

\subsection{The place of Russian in the construction of the Modern Bulgarian language}

Although its dimension is hard to determine, the linguistic affinity of Slavic peoples was undoubtedly a very important fact in their history. The great closeness 
between modern Slavic languages was of great importance to the mutual interaction of Slavic peoples. The relationship between Bulgarian and Russian language is a case in point.

Old Church Slavonic (OCS), as the first Slavic literary language, was created by Cyril and Methodius for their mission of standardizing the language, and was used in translating the Bible and other Ancient Greek ecclesiastical texts as part of the Christianisation of the Slavic peoples ${ }^{62}$. It played a vital role in the history of the Slavic languages and served as a basis and model for later Church Slavonic traditions.

OCS spread to principalities of the Kievan Rus` in about 10th century, while retaining characteristically South Slavic lingusitc features. Later texts written there began to take on characteristics of the local Slavic vernacular (the spoken dialects of the Old East Slavic language), and OCS had diversified into a regional variety. With the spread of OCS throughout Kievan Rus, the vernacular absorbed a large number of loanwords and calques from Church Slavonic ${ }^{63}$, gradually shaping the Russian literary language. In the words of Russian linguist Victor V. Vinogradov, the influence of OSC accelerated and facilitated the process of the formation of Old Russian state language... It gave the Russian literary language diversity and broad stylistic variations. It (OCS) increased its (Russian) immeasurable wealth of expressive means."

The homology between Russian and Bulgarian facilitated the interaction between the two languages. Much later, during the Bulgarian National Revival, the 
Russian language, in turn, influenced the shaping of the Modern Bulgarian national literary language. The Ottoman rule interrupted old Bulgarian literary traditions, and since then, Bulgarian language developed mainly on the basis of national speeches. In this course, Russian language, due to its proximity to Bulgarian, introduced a large number of new concepts to the social and cultural life of Bulgaria, and thus became the major source of enrichment to Bulgarian national lexica ${ }^{65}$. And importantly, in many cases, not only individual words, but also the types of word-building were adopted in Bulgarian, which retained their productivity in later Bulgarian ${ }^{66}$.

At the time, the Bulgarian language accepted some Russisan vocabulary, in which some words originated from Old Church Slavonic were returned" in the newly built Bulgarian literary language. Here it is necessary to explain where the returned" words came from. Based on Slavic dialects and the Glagolitic alphabet, OCS was created and used to translate religious literature by Cyril and Methodius. For the reason explained above, pupils of the two apostles settled in Bulgaria with the support of Boris I, teaching at two Bulgarian literary schools in Preslav ${ }^{67}$ and Ohrid ${ }^{68}$. Therefore, the language, in its Bulgarian dialects, spread to other Southeastern and Eastern European Slavic territories, including principalities of the Kievan Rus. So linguists, particularly Bulgarian linguists, preferred to the expression of returned words" to reflect the mutual influence between Russian and Bulgarian.

The enrichment of the Bulgarian literary language during the National Revival, when there was no specific major changes in production and technology, occurred mainly in the phenomena of social and cultural life, and therefore, in the field of 
abstract notions. In connection with the introduction and development of secular education, the foundations of scientific, political and cultural terms were placed in Bulgarian language. Bulgarian teachers, textbook authors, publicists and writers used a large number of Church Slavonic and Russian words that were completely clear, accessible and natural to all Bulgarians. Thus a variety of words emerged in Bulgarian - verbs like наблюдавам (observe), старая се (endeavor), уважавам (respect), заявявам (declare), преодолявам (overcome), преподавам (teach)...; nouns as разписка (receipt), доклад (report), данни (data), задача (task), обстановка (environment), обстоятелство (circumstance), хазаин (landlord)...; adjectives such as усърден (diligent), сложен (complicated), способен (capable), опасен (dangerous), необходим (required)...; adverbs like непременно (necessarily), даже (even), вероятно (possibly) and many more. It was a long and complicated process, in which Bulgarian digested and assimilated the borrowings in different routes and on various conceptual and phonetic levels ${ }^{69}$. It should be noted that the influence of the Russian language on Bulgarian focused mainly on literary rather than oral area, which left space for selecting fully necessary words for Bulgarian ${ }^{70}$.

Comparing the vocabulary of the Bulgarian literary language with that of the national speech, it could be noticed firstly that the literary one possesses a rich reserve of words referring to abstract concepts related to both the fortunes of public life and all fields of knowledge and culture. These terms and words were added into the Bulgarian vocabulary within a very short time with the help of the Russian. 
The Bulgarian introduced from the Russian not only single words, but some ways of word-building. The new cultural influence from Russia in the mid-19th century brought to the Bulgarian the suffix - ниe" in building gerunds ${ }^{71}$. The gerunds with suffix -ние" initially appeared as literary variety of Bulgarian, and gradually their formal and semantic differentiation from that with Bulgarian suffix $-\mathrm{He}$ " became apparently. Therefore, Ivan Vazov pointed out that the Bulgarian gerunds were - не" (not - ние"), and should be retained in the literary ${ }^{72}$. As a result, there are many homeotic gerunds with two suffixes ${ }^{73}$ in the modern language. Generally speaking, -ние" gerunds mostly express the abstract meaning of a phenomenon or specific objects, differing from $\rightarrow$ He" gerunds which contain clear sense of verbal, i.e. the meaning of action in its process. Take затъмнение and затъмняване for instance, the former stresses the state of dimness, while the latter emphasizes the process of dimming-out. The phenomenon of bi-gerund" in Bulgarian is unique among the Slavic languages. Moreover, it is worthy to noted that the - Hиe" gerunds in the Russian attestedly originated from OCS.

Through the medium of Russian an abundance of international cultural terminology, formed mainly from Greek and Latin elements, penetrated Bulgarian. In the word-building of nouns, a number of basic types with specific suffixes were highlited: -изъм, for example варваризъм (barbarism), деспотизъм (despotism), цинизъм (cynicism), дуализъм (dualism); -ция, конституция (constitution), революция (revolution), цивилизация (civilization), прокламация (proclamation); -ор, редактор (redactor), професор 
(professor), автор (author); -ист, капиталист (capitalist), журналист (journalist), публицист (publicist), специалист (specialist), and the adjectives corresponding to them ${ }^{74}$. These words not only brought Bulgarian new terms, which the language had never dealt with before, but also, importantly, introduced to Bulgaria the universal European values and modern ideologies implied in those words.

Besides its language, Russia, as an empire, also exerted profound impact upon the development and enrichment of Bulgarian. As discussed above, Russia's influence helped the language to be freed in a short time from Turkishness, which was replaced by new cultural words of Russian (or OCS) origin and international cultural terminology adopted in the Russian. Benio Tsonev said, even though somewhat exaggerated, - ur language was formed by Russian. For many concepts, for which we had no words and forms, writers take them from Russian. Of course, our language was enriched with many words that we had the Bulgarian varieties, but our writers are not aware of them. Given the russisms ${ }^{75}$, we will by no means forget the great contribution of Russian literature. Because we adopted many cultural concepts through Russian books, being acquainted with Russian and European thought - in a word, the national intelligence developed in a short time, and this is a very important contribution." 76

During the national liberation movement, journalism and literature were developed at an unprecedented rate in Bulgaria. In the works and reports of Lyuben Karavelov, Pencho Slaveikov, Hristo Botev and other masters of speech, Russian 
linguistic influence obtained authoritative form and direction.

In contrast with his political hostility to Russia, Karavelov preferred literary lexical form in his articles on politics, i.e., his literary lexical elements mainly came from the Russian language and Russian literary sources. He was opposed to Bulgarian purism proposed by Ivan Bogorov, and insisted that language should develop naturally without excessive interference of grammarians and linguists who created words according to their beliefs. He criticized Bogorov's magazine Knigovishte za prochitane (1874), The goal of Mr. Bogorov is to expound, to develop and to refine Bulgarian language. The language in this magazine is pure Bulgarian, but no learned or unlearned Bulgarian will understand but Mr. Bogorov himself.",77

Slaveikov affirmed Russian influence on Bulgarian because he believed that the Russian loanwords were not foreign to the structure of Bulgarian and therefore were easily absorbed in the language of literature. He strongly objected to Bogorov`s critique on him for the use of borrowings from the Russian such as ръководство (leadership). In an article Slaveikov retorted, The ignorant Bulgarians indeed do not say ръководство, but they say ръка (hand) and водя (lead) ${ }^{78}$, and they use many words with suffix -ство. Therefore we believed that there will be no Bulgarian who does not catch the meaning оғръководство and then we do not see sufficient reason for removing the word." ${ }^{, 79}$

Botev inherited Karavelov's positive attitude towards the use of Russian loanwords, and he also accepted loanwords from other European languages going 
ahead.

According to B. Tsonev (1912), the influence of Russian began with the introduction of Russian church books. In fact, these books were Russian not by language but by printing place. The language used in these books was not Russian but Church Slavonic, in which some Russian phonetic features and specificities of certain words were recognized and accepted. As Andreichin (1977) pointed out, the real Russian influence should be found when Bulgarian started to be enriched with new lexicon directly from Russian.

Undoubtedly, the role of Russian, preserving OCS language tradition in the form of Church Slavonic, was in a sense a mediator between Old and Modern Bulgarian. Church Slavonic largely reinforced the closeness between the two related languages. The linguistic influence of Russian was part of the general cultural influence of the Russian socio-political, literary, historical and grammatical thought. The influence of Russian culture, due to particular closeness in language and historical experience with Bulgarian culture, created favorable conditions to accelerate spiritual development of the Bulgarian society. The linguistic influence was lasting and fruitful, which was conditioned by centuries of cultural cooperation and interaction between the two peoples; it also played a significant role in constructing the new Bulgarian literary language ${ }^{80}$. Furthermore, it is not exaggerated to affirm that with the help of the Russian language, the Bulgarian national figures obtained the instrument to educate and enlighten its people, laying the foundation for achieving their national goal. 
To sum up, the most significant tendencies in the development of Bulgarian literary language in the $19^{\text {th }}$ were as follows:

- $\quad$ to limit and eliminate the impact of Greek (as well as orientalism) in order to preserve the Slavic features and the national identity of the Bulgarian language;

- $\quad$ to establish the basis (criteria) of the Bulgarian literary language on the Bulgaria vernacular (dialectal) language rather than Church Slavonic, even though the traditional elements of the latter were still retained to a certain degree;

- $\quad$ to purify the language by substituting the loanwords (from Turkish and Greek ones to Russian ones) with words from the vernacular to highlight the national characteristics of the language.

These linguistic efforts were conducted in steps and phrases, and the role of Church Slavonic and Russian was transferred from replacer to replaced (weapon for defending the Slavicness in the beginning, the object of being purified afterwards), which reflected the Bulgarians` national aspirations for creating a purer new Bulgarian language with fewer foreign elements. It was a natural phenomenon that the Bulgarians fought against foreign elements that were no longer necessary in practice. They aimed to keep a healthy development of the language, rather than being interfered too much by any foreign language, Slavic or non-Slavic. By doing so, the national identity and dignity of the people would be preserved in a perennial form. Hence, many of the loanwords from Turkish and other Balkan loans were replaced by 
native terms. However, words borrowed from Russian remained in the language not only because they were Bulgarianized in form, but also because the Russian loanwords introduced and spread modern European values and cultures in Bulgaria. In this respect the history of the Russian and Bulgarian language presents a particularly clear example of fruitful development and enrichment through beneficial assistance.

However, until 1878, despite the obvious aspirations of Bulgarian writers towards a united literary practice, a diversity was retained, to be explained mostly by the absence of a single political and cultural center, as well as common and obligatory norms. The signing of the San-Stefano Treaty followed the frontiers of the dioceses of the Bulgarian exarchate, which was considered to conform most closely to the natural ethnic (i.e. linguistic and religious) boundaries of the Bulgarian nation $^{81}$.

In general, the Bulgarian language, in its course of development, contacted with neighboring non-Slavic languages of the Balkans and changed profoundly. The changes distinguish the development of morphology and syntax in Bulgarian from that of other Slavic languages. Moreover, during the five-century Ottoman rule, some Turkish, Persian and Arabic words were borrowed in Bulgarian. Therefore, to adapt to the national reviving movement, the construction of a modern Bulgarian language became especially necessary and imminent. Although the standardization of the language did not complete until the Liberation of Bulgarian in 1878 because of the absence of a nation-state with a strong centralized government and the threat of 
denationalization by foreign cultures, the language served as a unifying factor of national identity, enabling the Bulgarians to defend their national rights. Importantly, it drew attention of the masses, who were deprived of rights of education, reading their history and the glorious past with their own language. In this respect, the standardization also served as ideology, propaganda, and education.

\footnotetext{
${ }^{1}$ B. Spolsky: -Secondlanguage learning", Handbook of language and ethnic identity, edited by J. Fishman, Oxford: Oxford University Press, 1999, p. 181.

${ }^{2}$ W. Humboldt: Linguistic Variability and Intellectual Development. Coral Gables, Miami: University of Miami Press, 1971, p. 24.

${ }^{3}$ Sue Wright: Language Policy and Language Planning, New York: Palgrave Macmillan, 2004, p. 32-33.

${ }^{4}$ P. Brass: Language, Religion and Politics in North India. Cambridge: Cambridge University Press, 1974, p. 410.

5 Ibid, p. 412.

${ }^{6}$ Lewis B. Namier: Vanished Supremacies: Essays on European History, 1812-1918. New York and Evanston: The Academy Library Harper \& Row, Publishers, 1963, p. 31.

${ }^{7}$ Ibid, p. 34.

8 - Mition-state" is a concept reverse to -State-nation" (Sue Wright: Language Policy and Language Planning, New York: Palgrave Macmillan, 2004, p. 32.)

${ }^{9}$ Lewis B. Namier: Vanished Supremacies: Essays on European History, 1812-1918, 1963, p. 34.

${ }^{10}$ G. W. White: Nationalism and Territory: Constructing Group Identity in Southeastern Europe, Lanham: Rowman \& Littlefield Publishers, 2000, p. 8.

${ }^{11}$ Ibid, p. 179.

${ }^{12}$ Mari A. Firkatian: The Forest Traveler: Georgi Stoikov Rakovski and Bulgarian Nationalism, 1996, p. 8 .

13 The Preslav Literary School, in Bulgarian Преславска книжовна школа, was the first literary
} school in the medieval Bulgaria, established by Boris I in 886 in Pliska, and moved to the new capital Preslav in 893.

${ }^{14}$ Also known as $\bigoplus l d$ Bulgarian" in Bulgaria. The language was the first Slavic literary language. It serves as a basis and model for later Church Slavonic traditions, being used by some Eastern Orthodox churches (including in Romania up to about 1845) as a liturgical language to this day.

${ }^{15}$ Adrian Hastings: The construction of nationhood: ethnicity, religion, and nationalism, Cambridge: Cambridge University Press, 1997, p. 126. The activity of the brothers Constantine (later renamed Cyril) and Methodius, aristocratic Greek priests who were sent from Constantinople."

${ }_{16}$ Millet is a term for the confessional communities in the Ottoman Empire. It refers to the separate legal courts pertaining to personal law" under which communities were allowed to rule themselves under their own system. Christian community was one of them.

${ }^{17}$ About the -double yoke" during the Ottoman rule, the scholars have various points-of-view recently. The typical attitude of the earlier historiography of Bulgaria, represented by Marcia MacDermott's History of Bulgaria, 1393-1885 believed that the portrayal of $19^{\text {th }}$ century Greek cultural influence forming a threat to the emerging Bulgarian national consciousness; while some scholars such as Detrez discusses the common Greek Orthodox identity in the Balkans before the national awakenings, seeing the myth of the double yoke as an anachronistic projection of modern day Balkan states onto the past - a projection that disregards the relative novelty of an ethnicity-based nation state (Detrez, Raymond. 2008. Ezik i literatura v romejskata" obštnost. In Stanisław Gajda (ed.), Tożsamość a Język w Perspektywie Slawistycznej, 152. Opole: Instytut Filologii Polskiej 
Uniwersytetu Opolskiego). Although the debate on this issue has never ceased, the traditional views like the former above still dominate the main-stream discourse.

${ }^{18}$ Cell schools, most often located within monasteries, offered rudimentary primary education with a curriculum of mostly religious content (Crampton, 2007, p. 49).

19 Marcia MacDermott: A History of Bulgaria, 1393-1885, Allen and Unwin, 1962, p. 118.

${ }^{20}$ Borislav Borisov: The Language Circumstance and Language Policy in Bulgarian and Czekh in National Revival, Bulgarian Speech. 15(3), 2009, p. 59-66.

${ }_{21}^{21}$ Cited in History of Bulgarian Modern Language. 1989. p. 19.

${ }^{22}$ Hilendarski: Slavonic-Bulgarian History, 2006, p. 41-42.

23 Many Thracian survivals have been detected in the sphere of Bulgarian national costume and folk tradition." David Marshall Lang: The Bulgarians: from pagan times to the Ottoman conquest. Westview Press, 1976, p. 27.

${ }^{24}$ Here refers to the Early Slavs.

${ }^{25}$ Between the sixth and seventh centuries, large parts of Europe came to be controlled by Slavs, a process less understood and documented than that of the Germanic ethnogenesis in the west. Yet the effects of Slavicization were far more profound" (Geary, Patrick: Myth of Nations. The Medieval Origins of Europe, Prinston Paperbacks, 2003, p. 144).

The remainder of the native population and the Bulgars gradually became absorbed by them, adopting a South Slav language" (L. Ivanov: Essential History of Bulgaria in Seven Pages. Sofia, 2007).

${ }^{26}$ This could be sensed in the title of Preface For history readers and listeners", and the form of address in the book - Readers and listeners of Bulgarian nation".

${ }^{27}$ Damaskins were chronicle files of Church liturgical books. Damaskins gradually became ecclesiastical collections of edifying sermons and biographies. They appeared at the end of the $16^{\text {th }}$ century in the western Bulgarian lands and survived until the middle of the $19^{\text {th }}$ century. Most of damaskins were written in simple, accessible language for ordinary people. The Damaskin literature thus was accepted as a crucial ingredient of fore-Bulgarian national literature.

28 This view owes to B. Angelov in his article Paisii Hilendarski and the development of our literary language in $18-19^{\text {th }}$ century" (published in journal Slavist. 13-22, 1985). Hilendarski had a number of predecessors and contemporaries who largely expressed similar ideas and probably affected Hilendarski. Their literary activity and creativity shaped the cultural environment for the going-well of subsequent revival processes.

${ }_{29}$ B. Tsonev: History of Bulgarian Language, Vol. I, Sofia, 1919, pp. 80-94.

30 Saint Sophronius of Vratsa (1739-1813) was a Bulgarian cleric and one of the leading figures of the early Bulgarian National Revival. His only printed work, Nedelnik, had historical importance in initiating book printing in modern Bulgarian and establishing the Bulgarian vernacular as the literary language.

31 Yoakim Karchovski (1750-1820) was a Bulgarian priest, teacher, writer and an important figure of the Bulgarian National Revival. In his writings, he self identified as Bulgarian. Because his place of birth is in today's Macedonia, he is also thought to have laid the foundation of the Macedonian literary tradition. He devoted his life to the cause of education and worked for the establishment of a literary language comprehensive for the common people. His books were among the first printed Bulgarian books written in modern Bulgarian language after Nedelnik of Sophronii Vrachanski.

${ }^{32}$ Kiril Peychinovich (1770-1865) was a cleric, writer and enlightener, one of the first supporters of the use of modern Bulgarian in literature, and one of the early figures of the Bulgarian National Revival.

33 These principles are considered as the base of the modern Bulgarian. That is why the first national enlighteners are always elevated into divines although they did not involve in the work on the structure and norms of the language.

${ }^{34}$ From Paisii to Beron, $1820-1830$ s.

35 Dialectal language here refers to the variety of language that is a characteristic of a particular group of the language's speakers (Oxford English dictionary).

${ }^{36}$ Lyubomir Andreichin: The role of Church-Slavonic language in the construction of modern Bulgarian literary language", Textbook on History of the Bulgarian Literary Language. Sofia, 1979, p. 33.

${ }^{37}$ History of Bulgarian Modern Language, 1989, p. 90-91 . 
${ }^{38}$ Lyubomir Andreichin: From the History of our Language Development, Sofia: National Education, 1986, p. 54)

${ }^{39}$ A correct translate of the book's title is Primer with Various Instructions. It was a Bulgarian schoolbook and the first Bulgarian encyclopedia (Todorov, Nikolai, 1968, Bulgaria: historical and geographical outline, Sofia, p. 263). This was, in real sense, a tool book for children to learn reading and writing. The primer consists of ten sections: Forword, Primer, Prayers, Good advice, Smart responses, Fables, Various stories, Physical tales and Arithmetics, and the remaining sections are collection of famous events from ancient history, studies on plants and animals and mathematical science. Some of the animals are illustrated in a compendium sention. The primer earned its nickname, Fish Primer, since one of these illustrations, a whale, appeared on the back of the original edition.

${ }^{40}$ Lyubomir Andreichin: From the History of our Language Development, 1986, p.173-184.

${ }^{41}$ The work was entitled First Bulgarian Grammar" (Ньрвичка българска граматика" in Bulgarian).

${ }_{42}$ Georgi Genov: American Elias Riggs and his contribution to the Bulgarian National Revival. Historical Archives. Sofia, Issue 9-10, November 2000-May 2001 (in Bulgarian).

43 The Bulgarian linguistis call Old Church Slavonic -Old Bulgarian” („Старобългарски” in Bulgarian). In the middle of the $19^{\text {th }}$ century, August Schleicher, Martin Hatay and Léopold Gaytler saw that linguistic features of the fist Slavic literary works were identical to the features of the Bulgarian language. They introduced the term - Đld Bulgarian", which were taken by the Bulgarian entirely at home. It serves as a basis and model for later Church Slavonic traditions.

${ }^{44}$ Thomas Henninger. Balkanische Lexik im Schrifttum der Bulgarischen Viedergeburt, Neuried: Hieronymus, 1987, p. 49. For a comprehensive survey of the Bulgarian cultural revival and the influence of European enlightenment ideas on it, see Iliya Konev: Bulgarian Revival and Education, Vol. I, Sofia: BAN, 1983. Although not dealing directly with the Bulgarians but confined to the population of the Habsburg Empire, the work of Holm Sundhaussen, Der Einfluss der Herderschen Ideen aufdie Nationsbildung bei den Völkern der Habsburger Monarchie. München: R. O;dembourg Verlag, 1973 is the best study on the influence of Herder's ideas on the formation of an ethnic and national consciousness among the Slavs. it recognizes the immense influence of Herder's philosophy but warns that this influence should not be treated as a formative element outside the historical context, but rather as a model adapted to the needs and interests of the rising national ideologies. (This note is made by Todorova in her thesis - Eanguage in the Construction of Ethnicity and Nationalism: The Bulgarian Case".)

45 Cited in History of Modern Bulgarian Literary Language, 1989, p. 165.

${ }^{46}$ Cited in Maria Todorova: Language in the Construction of Ethnicity and Nationalism: The Bulgarian Case. Nationalities Affairs. 28, 2006. p. 15.

${ }^{47}$ G. Venedictov: Criteria of Renaissance Writers in Choosing the Dialectal Basis for the Bulgarian Literary language, Modern Language History Studies in the Nineteenth Century, Sofia, 1979, p. 15.

${ }_{48}$ Cited in Maria Todorova: Language in the Construction of Ethnicity and Nationalism: The Bulgarian Case, 2006, p. 15.

49 It remains to be pointed out that Church Slavonic as a major lexical source of Bulgarian, was not comparable with the vernacular (dialects) as the basis of the language.

${ }^{50}$ Maria Todorova: Language in the Construction of Ethnicity and Nationalism: The Bulgarian Case, 2006, p. 15

${ }^{51}$ Lyubomir Andreichin: From the History of our Language Development, 1986.

(http://www.promacedonia.org/la/index.html, accessed on Aug. 22, 2013.)

52 G. Venedictov: -Eriteria of Renaissance Writers in Choosing the Dialectal Basis for the Bulgarian Literary language", 1979, p. 16.

${ }^{53}$ Lyubomir Andreichin: From the History of our Language Development, 1986. (http://www.promacedonia.org/la/index.html, accessed on Aug. 25, 2013.)

${ }_{55}$ The History of Modern Bulgarian Literary Language (1989) appraised so.

55 The first Bulgarian informational and educational paper (Ivan Nikolov Raoev: Encyclopedia of Bulgarian National Revival Literature, Abagar, 1996, p. 121-122). It was released in Leipzig in three issues on the following dates, April 20, September 20, 1846 and January 1, 1847. The founder and editor was Ivan Bogorov. The language of the newspaper was close to the spoken vernacular during the National Revival.

${ }^{56}$ Also translated as Tsarigradski Week. 
${ }_{57}^{57}$ Bogorov: Subject of the Bulgarian Language, Tsarigradski Newspaper, Issue 456, Nov. 19, 1859.

58 Andreichin, L.: An important moment in the development of the modern Bulgarian literary language, Reports of Bulgarian Language Institute, 1968, 16, p. 517-520.

59 No clarification in bracket follows the neologisms.

${ }^{60}$ Cited in Bulgarian Language, IV, 1954/4, p. 308.

${ }^{61}$ This view owes to David Martyn when he analyzes the relationship between the purity of German and national identity in his paper -Borrowed Fatherland: Nationalism and Language Purism in Fichte's Addresses to the German Nation" (Germanic Review 72.4 , 1997, p. 303-315), which can be used also to explain the Bulgarian case.

62 Alexander P. Kazhdan: The Oxford Dictionary of Byzantium, New York: Oxford University Press, 1991, p. 507.

${ }^{63}$ Evolved from OCS. The local varieties of OCS are collectively know as the Church Slavonic language (Boris Gasparov, 2010, Speech, Memory, and Meaning: Intertextuality in Everyday

Language, Walter de Gruyter, 2010, p. 185.).

${ }^{64}$ Vinogradov, V. V. (1945). Russian Language (in Russian). Moscow. p. 36-37.

${ }^{65}$ Lyubomir Andreichin: From the History of our Language Development, 1986.

(http://www.promacedonia.org/la/index.html, accessed on Aug. 31, 2013.)

${ }^{66}$ Ibid.

${ }^{67}$ The Preslav Literary School was the first literary school in the medieval Bulgaria, established on the order of Boris I of First Bulgarian state in 886 in Pliska, and moved to the new capital Preslav in 893. Until the capture and burning by the Byzantines, the School was the most important literary and cultural center of Bulgaria and all Slavs, where Cyrillic was used as the official alphabet.

${ }^{68}$ The school was established in Ohrid (nowadays Macedonia) in 886 by Saint Clement for the same purpose simultaneously or shortly after the establishment of the Preslav one.

${ }^{69}$ Some Russian words and forms, against which there were equivalent Bulgarian words, were also introduced during the process.

${ }^{70}$ Lyubomir Andreichin: From the History of our Language Development, 1986.

(http://www.promacedonia.org/la/index.html, accessed on Aug. 31, 2013.)

${ }^{71}$ The original Bulgarian gerunds end in $\rightarrow$ He"

${ }^{72}$ Ivan Vazov: In the depths of the Rodopi, Collection of Folklore, Science and Literature, Vol. 8, 1892 , issue 2, p. 11.

${ }^{73}$ The two noun forms from one verb.

${ }^{74}$ In both of the two works - From the History of our Language Development (1977) and History of Modern Bulgarian Literary Language (1989), the authors clarified this in detail.

75 Русизъм in Bulgarian, refers to borrowing word from the Russian in other languages. In addition to this, this is also a slang term for a nationalist ideology justifying the Russian superiority over other nations.

${ }_{76}$ B. Tsonev: History of Bulgarian Language, Vol. II, Sofia, p. 344-345.

${ }_{77}^{7 n}$ Independence, 1874.

78 Ръководство is a compound noun composed of ръка (hand) and водя (lead), and ends with suffix - Ство.

${ }^{79}$ Cited in the History of Modern Bulgarian Literary Language (1989), p. 231.

${ }^{80}$ Rumyana Bavlova: Bulgarian-Russian and Russian-Bulgarian Linguistic Ties (in Russian), Sofia: National Education Press, 1979, p. 143-144.

${ }^{81}$ Maria Todorova: Language in the Construction of Ethnicity and Nationalism: The Bulgarian Case, 2006. p. 16. 


\section{CHAPTER 5 IVAN VAZOV'S UNDER THE YOKE -}

\section{NARRATING THE TIME}

Literature, based on factual information, reflects the various experiences, ideas, passions of ordinary people in their daily life, which helps us to investigate the values and manners of the society in a given period. Under the Yoke (1894) by Ivan Vazov is celebrated as a romance of Bulgarian liberty". The subtitle of the novel is From the Life of the Bulgarians on the Eve of the Liberation. Set against the background of the tragic April Uprising in 1876, it is an extended examination of Bulgarian character and the national awakening. Reading this powerful and historical novel enables one to discover the clues about the Bulgarian nation-building process and the formation of the Bulgarian nationalist discourse - the hatred against Turkish tyranny.

\subsection{The author and the work}

Ivan Vazov, the most distinguished writer in the history of modern Bulgarian, was born in Sopot (Balkan valley), a large Southern Bulgarian village in what was later known as Eastern Rumelia in 1850. He studied in Sopot and Kalofer with Botio Petkov, the father of Hristo Botev, and worked together with him. His literary interests were inspired and formed during this period mainly under the influence of French writers such as Victor Hugo. From 1870 to 1872 , Vazov, like so many 
educated Bulgarians of the time, resided in Romania, where he became involved with Bulgarian revolutionary circles. In 1875 he returned to Sopot and joined the revolutionary committee. But after the uprising of 1876, he emigrated again to Romania for safety, and joined the Bulgarian Revolutionary Committee at Bucharest. The three years that followed saw the publication of three volumes of his lyrical poetry, The Banner and the Guzla, The Sorrows of Bulgaria, The Deliverance, describing the progressive story of Bulgarian liberation. He returned in 1878, when Bulgaria regained its independence as a result of the Russo-Turkish War, and wrote the famous Epic of the Forgotten. Then Vazov moved to Plovdiv, the capital of the ephemeral autonomous principality of Eastern Rumelia, a principality that was united with the Bulgarian principality in 1885 , and worked as a member of the Permanent Committee of the Provincial Assembly. This was also the period when some of his most important literary works were published. In 1886, under the regime of Stefan Stambolov, dissatisfied with the turn taken by affairs in the peninsula after the abdication of Prince Alexander of Battenberg, Vazov left for Odessa, where he wrote his novel Under the Yoke (1889), which gained him international fame. After the fall of the Stambolov regime he returned to Bulgaria and lived in Sofia until the end of his life.

Vazov was considered the Hiving patriarch of Bulgarian literature". He was the main mediator between the romanticism of the National Revival and the institutionalization of the national ideology in the modern state. He was self-consciuos of the symbolic value of his literary work and reacted as a $\forall$ oice of 
the people" to all important historical events in the first half-century of the existence of the independent Bulgarian state ${ }^{1}$. Vazov's work extended to as far as all genres of the Bulgarian literature during his lifetime - poetry, prose, travel sketches, essays and plays, contribution to the formation of the Bulgarian nationalist discourse and must-reads for the textbooks in Bulgarian schooling system even until today.

For more than 50 years, Ivan Vazov was the most highly regarded figure in Bulgarian literature. He wrote compelling works to glorify Bulgaria's national reawakening and to articulate the ideas of the past. His view of the Bulgarian national character had an enormous impact, and to this day his works remain an invaluable treasure of Bulgarian literary history.

Naturally, there is a lack of critiques since his first published work. Dr. Krastyo Krastev criticized Vazov for his storytelling in purely external technique with shallow psychological analysis ${ }^{2}$, holding that If short story could be written to some success without great psychological deepening, the writing of a novel is not the case... If the author does not know how to plant his character in deeper psychological and ideological thoughts, the novel might just be a collection of 'interesting' adventures and amazing coincidences. Vazov`s novels acturally are things alike, and therefore, their importance is mainly in ethnology instead of artistry."3 More often, Vazov`s works were denounced as high-toned" and propagandistic because the his characters are mostly portrayed as hero of effect, rather than hero of action".

Regardless of praise or censure, Vazov's literary creation established the measure of Bulgarian national and cultural identity, forming the key literary 
paradigms" of native Bulgarian - language, history and memory, nature, art, individual and society ${ }^{5}$. The interpretation of Vazov and his works also points to the theme of national self-knowledge and the construction of Bulgarian national space, in which the novel Under the Yoke occupies an unshakable position in the course of seeking the steadiness and fluidity of the national being ${ }^{6}$.

Under the Yoke creates an epic fictional representation of the April Uprising - a crucial episode in modern Bulgarian history. Boicho Ognyanov, a Bulgarian revolutionary imprisoned in Anatolia escapes and comes back to Bulgaria, to the town of Bela Cherkva (White Church) in the Balkan valley. There he is integrated gradually into the life of the community, aiming to lead the organization of the national revolution. Eventually, the uprising breaks out before the due date because of betrayal, which results in a catastrophe: the leaders of the movement perish, and at the end of the novel so do Ognyanov and his beloved Rada.

The novel commemorates the April Uprising of 1876, the culmination of the Bulgarian revolutionary movement, by transforming this dramatic historical event into a national myth. Along with the writer's earlier Epic of the Forgotten that glorifies the leaders of the uprising and the people who rose in revolt, and the famous Notes on the Bulgarian revolt 1870-1876: Narrative of Eyewitness by Zahari Stoyanov $^{7}$, Under the Yoke opened the way to the canonization of the uprising as a sacrificial founding event. These three texts served as a paragon of the national ideology, in which the myth of national martyrdom in the April Uprising acquired a constitutive function ${ }^{8}$. Stoyanov regarded the Uprising as a major identity-building 
event, saying that We possess no other more glorious past that characterizes us as people"9. As a major identity-building event, the Uprising also became a bone of contention of different ideologies. In spite of some dissenting views, the mainstream interpretation remained the one promoted by Vazov and Stoyanov, which considered the event as a quintessential emanation of the national self (heroism and martyrdom $)^{10}$.

Chapter VII of Under the Yoke - A nation intoxicated" embodies the emanation of the national self". It is an attempt to devise a canon of national revival", starting with the cultural nationalism initiated by Paisii Hilendarski's Slavonic-Bulgarian History, and culminating in the armed April uprising. The chapter depicts revolutionary enthusiasm at its climax. The whole nation emerges as a homogeneous, organic, ecstatic and sacrificial body, in difference in social strata disappeared, effaced by the force of the common -madness": the will to be free, or to autonomous $^{11}$.

Naturally, there was considerable disagreement about Vazov's Under the Yoke, one of the most controversial works in Bulgarian literature in its more than 110-year life. After the first wave of ecstatic reviews on the novel, when literary critics such as Krastyo Krastev (Vazov's literary enemy in the subsequent years) compared the novel with The Iliad by Homer, a wave of mixed critical remarks followed. It is worthy to note that the criticisms were mainly focused on the artistic expression of the novel ${ }^{12}$. Very few critics challenged the authority of this work in its contribution 
to the formation of Bulgarian national identity, even though it is always seen as a \#ationalistic propaganda".

Until today, Under the Yoke also enjoys a high popularity among Bulgarian readers. In 2009, this novel ranked first in the list of the most widely read and loved books in Bulgaria.

\subsection{Air of Bulgaria}

From the life of the Bulgarians on the eve of Liberation", the subtitle of Under the Yoke leads us to closer to the very essence of the work, that is, the ordinary Bulgarian life in the grand historical background. Despite the presence of a central storyline of romantic adventure related to the protagonist, another artistic object could always be sensed- the pure Bulgarian lifestyle, the mentality and historical destinies of the people. At this point, the adventure of the romantic knight of the national revolution, Boicho Ognyanov, is merely a bright leading thread, which helps to explore more deeply the living and realistic image of the Bulgarian community and to instill national pathos of the time ${ }^{13}$. Owing to this, the novel is always defined as the most-Bulgarian book", -air of Bulgaria", -encyclopedia of national life" and so forth.

As is mentioned above, Under the Yoke was created mostly in the year of 1887-1888 in Odessa, where Ivan Vazov found refuge after being expelled from Bulgaria. Ifelt much grief and pain for losing my homeland," the author said in the preface to the fifth edition of his work in 1920, - My mind, my heart, my soul were 
constantly flying towards him. When the inspiration to write this novel came to me, I breathed again the air of Bulgaria."14

Air of Bulgaria" - this is actually the most accurate definition of the artistic atmosphere of the novel given by the author himself. Without refreshing touch to the homeland, the whole spirit of Vazov would lose vitality. He was involved in his novel, an escape from deep nostalgia. But the spirit of nostalgia was just the emotional impetus which the author did not express directly in the work. It was an organic expression of his inner life and historical experience, crystallization of unforgettable memories of pathetic days of his youth.

At the very beginning of the novel, presented is a scene with the most characteristic Bulgarian family life during the years of slavery. Vazov describes a set of habits in a typical Bulgarian patriarchal family in Chapter I A visitor" - dinner in the yard with a complete circle of children", peculiar upbringing by the everyday and festive religious custom, love and trust in the air of the family, and so on. The author defines it as a kind of super value that keeps the traditional Bulgarian virtues ${ }^{15}$. Chorbadji Marco is the head of the family, symbolizing the typical Bulgarian honest, well-judged, respectful to Christian values, progressive and patriotic. His wife is the typical Christian wife - humble and obedient, devoted to her husband, carrying the responsibilities of raising and educating children.

Vazov fills the daily round with historical flavor to convey the historical specificity of the Bulgarian living custom. Unlike the description of living traditions in the literary works of other contemporary writers ${ }^{16}$, which manifests spiritual 
pursuance by illustrating the costume the character wears, Vazov discovers the spiritual essence of the era and the bright human characters growing on the soil of a particular lifestyle by depicting the everyday life of the people. Moreover, Vazov has an extraordinary aptness to record history by some credible living evidences, customs and even the practical daily life of a bygone time. Of course, due to his his sense of artist, he adds artistic function to the most typical ethnographic details. A typical case of this is the image of Marko's living room, in which a memoir-chronicle of Bulgarian life is unfolded before the reader's eyes:

The guest-chamber into which they entered was a small room, but bright and airy. It was furnished and ornamented in the unassuming and original manner which even now holds sway in some of our provincial towns. The floor was covered with bright carpets, and the two divans with scarlet rugs, all home made. Against one of the walls stood an iron stove, which was lighted only in winter, but was not taken away in summer, as being one of the ornaments of the room. Opposite to it, on the eikonostasis, where a light burned continually, were nailed eikons, over which hung sacred prints from Mount Athos, a pious gift from pilgrims. The eikons were very old paintings, which made them all the more precious to Grandmother Ivanitsa, as old arms are to collectors. One of them, of great antiquity, enjoyed the most reverential attention of the old lady, who asserted with pride that it had been painted by her great-grandfather. Father Hajji Arseni, who had accomplished the miraculous work of art with his feet - an assertion no one ever ventured to controvert, so confidently did she make it. Behind the eikonostasis was fastened a bunch of dried cornflowers, which had been sprinkled with holy water, and a willow branch from the decorations of last Palm Sunday. The presence of these in a house was an infallible preservative of health and prosperity. Round the walls ran shelves filled with porcelain dishes and cups - the inevitable decoration of every house worthy of respect - and the comers were furnished with triangular brackets on which stood flower-vases. Chibouks, as an article of use, had long since gone out of fashion, but these were ranged against the wall, with their yellow amber mouthpieces and inlaid bowls. Marko, for old tradition's sake, kept one chibouk for his private use.The wall opposite the windows played the important part of picture-gallery. In all, it contained six lithographs, in gilt frames, brought from Wallachia. Their strange selection bore witness to the easy-going taste of the time in matters artistic. Some represented scenes from the internal wars of Germany- one was a picture of Abdul-Mejid on horseback, with his suite. The next portrayed episodes of the Crimean War: the battle of the Alma, of Eupatoria, the raising of the siege of Silistria in 1852. The last picture of all 
represented the Russian generals in the war, all depicted down to the knees only. Pope Stavri asserted that their legs had been cut off by the Enghsh cannon, and on the strength of this Grandmother Ivanitsa always called them the martyrs". Who has been touching the martyrs?" She would ask angrily of the children. (21-22)

Underneath this long detailed description of the furnishings in Marko's living room, a number of connotations are implied. First, the Bulgarian household has firm belief, and the members are all most pious and self-disciplined Orthodox Christians. They strictly preserve the Orthodox tenets in their domestic life: the light burned continually on the eikonostasis ${ }^{17}$, the place where the sacred pictures or eikons are placed against the wall; the old-painting eikons, particularly the one painted by the grandfather; the dried cornflowers sprinkled with holy water and the willow branch from the last Palm Sunday... All these represent the anchorage of the family's faith, bringing health and prosperity at the same time. It is well known that icons are important in the Orthodox spiritual life. In both churches and Orthodox households, icons are put in their proper place. In Orthodox homes, the eastern corner of a centrally located room is always dedicated to the display of icons, which features at least one vigil lamp hanging before it, religiously and perpetually kept burning by the members of the family. The icon veneration represents a peculiar aspect of the Eastern Orthodox ethos, which can be properly and authentically understood within the context of that ethos and of the civilization that created it and its unique identity" ${ }^{\prime 1}$. It is conceivable that how the unique -symbol" of Orthodox Christian helps the Bulgarian household preserve firmly their religious identity during foreign dominance. Faith, as a basic Christian postulate, is an important spiritual support in hard life, giving the people hope and uniting them in one. Bulgarian" is synonymous 
with righteous Christian" ${ }^{\prime 19}$. The pious faith reminds each family members of their national properties of being Bulgarian, strengthening the sense of national belonging. Historically, belonging to the Christian Church was the first national identifier of the Bulgarians, which distinguished them from other ethnic groups in the Ottoman Empire, and it was also a sign of their unity in the spiritual term.

Second, the author's love for all things Russian is noticeably apparent in this description. When it comes to the wall opposite to the window with six lithographs, Vazov (might be Marko) compares it to Ermitazh ${ }^{20}$, which refers to the State Hermitage Museum of Russia ${ }^{21}$. This analogy is not very appropriate, but it seems that the author does not really hope to give an exact analogy; rather, his main purpose is to show his preference and admiration for Russia ${ }^{22}$.

The great historical conflicts of the time stand at the center of the novel - the pathetic moments of extreme peril for the nation, which ends with the heroic April Uprising. However, the author does not pay much attention to the depiction of the conflicts, rather, he gave a good picture of everyday life in the context of the great historical change. Vazov shows exactly how the April Uprising goes through the spiritual world of ordinary, peaceful Bulgarians and outlines the historical track in the national consciousness ${ }^{23}$.

In the compositional scheme of the novel, the author works on some life discriptions, which are seemingly irrelevant and have no essential function with the adventure plot. The famous drama performance of Suffering Genevieve" is a good illustration. 
The drama Suffering Genevieve", which was to be given that evening at the boys' school in the city, is probably unknown to the youth of the present generation, according to the Vazov. But he gives a specific introduction of the drama, and a more specific description of the ardent reaction of the local population to the performance. He sees the drama, which had acquired the most extensive polularity and enchanted the whole population of the day ${ }^{24}$, as a part of the tradition life in the city:

This naive and moving conception has at various times brought tears to the cheeks of every old woman and young bride in Bulgaria. At the time the scene of this story is laid, every one knew the plot, and many had the whole play by heart. This is why the forthcoming representation had caused such excitement among the townspeople. It was impatiently awaited as a great event, which would be a pleasant change in the monotonous life of Bela Cherkva. Everybody was looking forward to it. The richer housewives had got out their best finery, the poorer had sold their yarn in the market and at once invested the proceeds in tickets, instead of making their usual purchases of salt or soap. Nothing but the theatricals was talked of at family and social gatherings (91).

The seeming overreaction to this faive" drama helps illustrate the inner essence of the Bulgarians at the time - treasuring their habits, their preferences and trying to keep them in the life of being enslaved. Watching the performance is a way to release their pent-up feelings. Including but not limited to this, all of the traditional memories repose their national feelings, keeping their specialties of being Bulgarians.

Of course, the depiction of living scenes aims not merely at introducing the Bulgarian life style, it always leads the reader to some scenes transcending life itself. The author easily interweaves descriptions of daily life with preach suited to the era. In the episode of the show Suffering Genevieve", the author, on the one hand, narrates the gathering audience with different levels of education and taste, their various reactions to the performance of individual role, displaying the diversity of 
aesthetic, cultural and language preferences in the pre-Liberated time.

In the same chapter The Theatricals", the author narrates the comments of the audience, to which he keeps a kind-ironic intonation, laughing at the tears trickling down the women's and even some of the men's faces. But when the action touches the main patriotic fervor, the author narrator immediately speaks explicitly of unambiguous words with pathos, which proves his deep connection with the feelings of the characters in the sublime moments:

But after the first two stanzas of the song had been gone through, suddenly on the stage broke out the revolutionary song :

Blaze forth, fond love of fatherland.

Till 'gainst the Turk arrayed we stand!

The sound fell like a thunderbolt upon the audience. At first only one voice had begun, one by one the whole troupe joined in, and it spread gradually till the entire audience took it up. A sudden and patriotic enthusiasm filled all those present. The bold and stirring air spread like some unseen wave, filled the hall, passed the threshold, and was wafted abroad into the night: it overcame every other sound, and sent a hot and fiery emotion through the blood. Its powerful notes awoke a new chord in the audience. Every one who knew the song sang it in chorus - men and women. It drew all hearts with it, united the actors and the audieuce, and rose to heaven like a prayer (98).

That brings us to very special, overlapping rhythms - seemingly peaceful and habital everyday life on the one hand, national spiritual fervor of the reviving era on the other. Both survive in the body of Bulgarians - the former takes the form of living normality, while the latter is hidden in the mind of everyone and will be released when required.

The picturesque description of the Bulgarians' everyday life is Vazov's way to seek for a sense of national belonging, by which he helps the ordinary people to cherish their national properties and rediscover the national selfness under the foreign tyranny. 
The picture of domestic life of the Bulgarians drawn by the author, has an authentic link to the spiritual life of the people, in which the foundation of patriarchal moral and spiritual revival that has overtaken the soul of everyone could be sensed. The depiction of Bulgarian daily life blends with that of the spiritual world in harmony. In the courtyard of Marko, in Ganko's cafe, in every possible place the people manifest their spiritual pursuit.

One of the most significant spiritual pursuits is to educate children and youths how to become a worthy Bulgarian. Vazov emphasizes the importance of knowledge for the formation of the Bulgarian national consciousness through Marko's emphasis on secular education and the people's thirst for knowledge.

Thanks to the wisdom and progressive thinking of Marko, he finances the local education and requests the children to receive education. He has a dim notion that it will be favorable for his nation, although he has a very limited understanding on the educational cause itself:

For though he had but little education himself, he loved learning and the learned. He was one of those numerous patriots whose eager zeal for the new educational movement has in so short a time filled Bulgaria with schools. He had but a dim notion of the practical benefit likely to accrue to a nation then consisting almost exclusively of farm labourers, artisans, and merchants... he understood in his heart that some secret force lay hidden in learning which would change the world (2).

The thirst and craving for science, wisdom and knowledge is so pervasive among the people that the annual examination" attracts the entire community. The old come to enjoy what youths have learnt, ensuring the opportunities of the new generation. For the young this exam is a playing field for justifying the assigned hopes on them, and for educators it is a proof that the seeds sowed will bear lush 
fruit.

The theme of education appears many times throughout the novel. Chorbadji Marko, unlike other characters, is not a devotee of revolution. He believes in the cause, risking his life for it on several occasions and even donates his cherry tree to the artillery effort, but he does not immerse himself in the cause as Ognyanov and Sokolov does. His support for both education and the revolution is intended as an example to the people. Vazov hopes that all of his readers, even the most ordinary of them, will follow this example and support sciences and education, on which the hope of the nation is pinned.

Another example of support for education is a more subtle one. Ognyanov, who serves as an example of the ideal revolutionary, takes the job of schoolteacher in Bela Cherkva. Rada, Ognyanov‘s beloved and the feminine Bulgarian ideal, also works as a teacher at a girl's school. By giving these characters occupations in education, Vazov is emphasizing education's role in the revolution and ascribing great prestige to educators.

Along with the general knowledge, the author definitely expresses his attention to history, expecially the history related to the Bulgarians, which serves as a mandatory part of school education. In the annual examination, the subject to be tested is the abridged history of Bulgaria. The three questions mentioned explicitly are all without exception related to the glorious past of Bulgaria:

Which Bulgarian Tsar introduced Christianity among us - made us Christians? Who invented the Bulgarian alphabet? 
Which Tsar it was that freed the Bulgarians from the Greek yoke?(61-62)

Both the writer and the educator in the novel intend to draw people's attention to the brilliant history of Bulgaria. The respect to history is to look for the national belongings, as well as to find the basis of national identification. For the people enslaved, this is a direct and effective approach to awakening the national consciousness and ambition.

\subsection{An emanation of the national Self - heroism and slavishness}

In Vazov's novel, Bulgarian heroes Ognyanov and Stomatov recapitulate the ideas and themes of the Bulgarian Nationalist Revival Movement in graphic form as they valiantly and violently seek to defend the Bulgarian national homeland against the Turks ${ }^{25}$. Ognyanov, the protagonist of the novel, is portrayed as a nearly ideal image of the time - a national hero, a fanatic patriot and a loyal servant of his homeland. The character creation embodies to a large extent the ideal self-image of the Bulgarians - the sparkling national features inherited from the folkloric tradition, particularly the so-called heroic rebellion songs of Hajduk ${ }^{26}$, for liberating the long-suffering people from foreign tyranny. The national Self is chiefly based on the desire to preserve the national values associated with the term Bulgarian" and patriotism". The formation and consolidation of such personal models is firstly oriented to heroism and national resistance against foreign domination, and then to the willingness of self-sacrifice for the national goal. 
Many examples in the novel represent the readiness for heroism, although some of them take a modest and subtle form. In Chapter I, when Grandma Ivanitsa terrifies the kids with the Turks, the little Peter replies, Ah! Grandma, when I and brother Vassili and brother Georgi grow up, we'll take our scythes and kill all the Turks (4)." Despite the marked naivety, what these words reveal is not merely getting over the fear of the Turks, but looming in the national mentality readiness for fighting. This readiness has not yet been fully realized among the entire population, and thus it is often expressed through the words of the children or drunkards in literal and figurative sense. Vazov connects this model of drunkard with the intoxication of patriotic ideals, and with the madness of Bezportev in Chapter -Marko's prayer”:

Hurrah! Marko! Hurrah for you and for Bulgaria! And all her brave sons! ... I'm as drunk as I can be - that's so - but I know what I'm about. Yes, I'm a true Bulgarian. I see the sufferings of the nation - that's why I say, We've had enough slavery and drunkenness: we'd better die than go on like this." They may say: You're as drunk as a Russian sapojnik" (cobbler). Whoever says that is a traitor. My heart is sore for Bulgaria, that poor slave of the Turks. All we want is our rights - the rights of humanity. We seek not fame nor riches, we seek not land nor wives."27 But you may say people do get married, how about that? Well, I answer, that's the way of the world. If the word's given tomorrow: Forward, march, set fire to your houses, and off we go to the Balkan! A man who's afraid of the birds doesn't sow millet - you know what I mean! Long live all patriots like you - I'd kiss their hands and their feet... Why, I'm as drunk as a - as a . . . It's love for my country that makes me drunk. The hour's nigh. I'm alive today - but tomorrow I may be dust-ashes-nothing. It's a fool of a world, and that's the truth. And whoever dies for the nation will live for ever and ever. Hooray! Long live Bulgaria! (197-198)

The words and behavior of the drunken Bezportev are expressive. Once again they are situated amid a domestic scene - wedding dance Khoro ${ }^{28}$ that marks not only the Bulgarian national property, but also the direct allusion to the Uprising, in which heroism will be the only measure of patriotism. To reveal that idea of his, the author depicts the drunk Bezportev from the perspective of Chorbadji Marko: 
On his pale, elongated and bony face, with its red moustache and twinkling grey eyes, was depicted a certain wild glee and excitement produced by intoxication (197).

This part of the novel is not written by accident. It conveys to a large degree the authentic moods of ordinary Bulgarians, identifying the patriotic feelings with drunkenness and intoxication of ideals related to the freedom of their homeland. The pursuit of the heroism rapidly turns the people (men and women, old and young, rich and poor) into -a nation intoxicated":

They listened, they swallowed thirstily every word of that life-imspiring speech, even as the parched throat does the refreshing draught. In response to the appeal, $\mathrm{Be}$ ready, we must die!" the church gave its pope, the school its teacher, the field its ploughman, the mother her son. The idea struck its roots everywhere with invincible force - it spread over all alike - over Balkan and valley, over the hut of the poor shepherd and the cell of the monk. Even the Chorbajis, who formed a close caste opposed to all national development, even these fell under the sway of the idea with which every brain was on fire (201).

Here the author, turning to the events of 1876 , depicts revolutionary enthusiasm at its climax. The whole nation emerges as a homogeneous, organic, ecstatic and sacrificial body, in which the different social strata have disappeared, effaced by the force of the common madness": the will to freedom, or to autonomous national existence. The metaphor of madness" represents the epitome of the ideological pathos of the novel ${ }^{29}$, as well as a release of the Bulgarian national Self.

If heroism emerges without being accompanied by loyalty to the noble national cause, it would be futile. Loyalty is one of the qualities most highly praised by Vazov. Ognyanov and his beloved Rada, and Sokolov all exhibit supreme devotion to the cause of national liberation. At the end of the novel, all three characters willingly die for the cause, with Ognyanov and Sokolov both saving enough bullets to ensure they will not be taken alive. They accept their fate voluntarily, the recently reconciled 
Rada and Ognyanov content to die with each other, which represents fidelity to love. The importance of fidelity to love in the relationship between Rada and Ognyanov is also meaningful in that it represents Ognyanov's ideas of loyalty. At the first hint of infidelity on Rada's part, with only the slightest evidence backing it up, Ognyanov cruelly scorns her. This emphasizes the value Ognyanov, and by extension, Vazov, places on loyalty. The loyalty to love and to national cause make them choose self-sacrifice as another form of existance, more mental and spiritual.

However, the national self image in the work of Vazov is by no means unitary; rather, it always shows the multidimensional, sometimes contradictory quality. The story of Under the Yoke is determined by the nature of the historical event described the preparation, the outbreak and suppression of the April Uprising. In this sense, the novel is a story about how the obedient are transformed into rebels, and their metamorphosis again into over lowly loyalists of the Sultan. Therefore, the movement of the public spirit of the time is uneven, non-linear. It has its various phases - the meeting of the people of Bela Cherkva with Ognyanov, mass revolutional enthusiasm, the stifled insurrection, returning to the slavish fear positive and negative moral tracks. The basic romantic motives play an important role in building the dynamic public image, that is, motive about madness, sight and honor. The semantic threads set by the motives are perfectly consistent:

philistine rationality - rebellious madness - coming around; historical blindness - patriotic sight - new blindness; slave dishonor - revolutionary honor - new dishonor. 
To clarify this question, it is necessary to study the interaction (conflict and cohesion) between the revolutionary apostle and the community, in particular, the ideological role of the engine of change (Ognyanov) and the reception of the community of Bela Cherkva. Early in Chapter I A visitor"of the First Part, the complicated dual character of the national mentality is highlighted. The initial episode introduces the traditional view of life, as discussed above. Markov's home symbolizes the Bulgaria on the eve of preparing for the outbreak of the April Uprising. On the one hand, the political interests of the householder (cult of Russia and the ancient history of Bulgaria, hatred for the Turks) suggest that the Bulgarian home catches the smell of national revival. On the other hand, however, both spatial and spiritual isolation of the home (high walls around the house, the actual fear of the Turks, conservative habits at home) indicate that ordinary Bulgarians have not had the idea of resistance, obeying the rules of tradition and foreign yoke.

The sudden appearance of the -escaped convict" stimulates the awakening of the untraditional image of Bulgarians. The meeting of Marko and Ivan Klalich (the original name of Ognyanov) represents the meeting of two value systems (familiar and social), and of two psychologies (reconciliation with slavery and revolutionary intransigence).

Then the resisting instinct of the people is awakened. The masses, stirred by Ognyanov, are intoxicated with the coming revolt. But things go downhill soon afterwards. If the living conditions of Bela Cherkva's residents prior to the meeting represent tolerance and respect to tradition of the local Bulgarians, the comportments 
of the majority after the abortion of the April Uprising reflect their obedience and compromise. For the tolerant character, Vazov's comments on the life in Silistria are well on mark:

Where the arena of political and scientific activity is closely barred, where the desire of rapid enrichment finds no stimulant, and far-reaching ambition has no scope for its development, the community squanders its energy on the trivial and personal cares of its daily life, and seeks relief and recreation in simple and easily obtainable material enjoyment... An enslaved nation has a philosophy of its own which reconciles it to its lot. When a man is irretrievably ruined, he often puts a bullet through his head or ends his life in some equally rapid and decisive manner. But a nation, however hopeless its bondage, never ends its own existence; it eats, drinks, begets children (70).

The lack of spiritual claims and political participance enable the people to forget the state of virtual slavery. It is also worthwhile to note that right under this ciucumstance, the Bulgarians saved their faith, custom and many other national properties, and consequently preserved their full nationality. While we breathe, there is hope", this is concept of existance which makes the nation enduring and long-lived.

But when the Uprising is stamped out in a few days, what the masses do reflects the weakness of the national character, which the writer accuses indignantly:

To every sheepfold and Bulgarian hut strict instructions had been given not to afford hospitality to any suspicious-looking wayfarer. The Bulgarians did even more: they pursued all such and hastened to inform the patrol; indeed, their zeal often went so far that they finished off with a bullet some wounded or half-starved insurgent. A fortnight before, these same shepherds had welcomed the apostles as the dearest of guests (253).

The most gloomy, but natural offspring of the ill-fated revolution is cowardice, egoism and treachery everywhere in the town. Uncle Marko, the generous contributor of a cherry-tree cannon, becomes the victim of some treachery; so was Kandoff. Interestingly, two small figures express their warmness and humanity in contrast with 
the overwhelming public egoism. One of them is Milka Todorichkina, an unaccepted slut (in vulgar eyes), who gives harbor to Doctor Sokolov, showing her negation of selfishness. The other one is Mouncho, a harmless idiot. He is the only man who ventures to protest when he sees Ognyanov's head hung on a pole. These two seemingly marginal figures represent the real and pure quality of the nation behind the mask of either enthusiasm or cowardice. This is the only hope that the writer placed on the masses after the disastrous failure of the Uprising. For him, cowardice and treachery are not the essence of the national Self; rather, the true Self is smothered by the despotic power of the Turks and presented by the obedient character. In other words, the evil Self is merely a product of being enslaved by the evil Other, behind which the true Self appears indistinctly.

The ideal national Self image (heroist, represented by Ognyanov) and the tractable, docile image (obedient masses of Bela Cherkva) coexist in the novel, alternatively dominating the people's mind. Both have their own value. For the former it is needless to say; for the latter, the protagonist Ognyanov gives a meaningful explanation: It's a sign of our existence, at least. No one troubles about the dead - only the living have a right to life (292).

\subsection{The two Others in the work}

In the novel, Bulgarian heroes Ognyanov and Stomatov recapitulate the ideas and themes of the Bulgarian National Revival movement as they valiantly and violently seek to defend the Bulgarian homeland against the Turks with the help of 
the Russians. Turks and Russians, the two non-Bulgarian image are portrayed as two Others, towards whom the Bulgarians take totally opposite attitudes.

For the Bulgarian residents in Bela Cherkva, Turks are \#nequivocally cruel, if not bestial, alien interloper(s), occupying and preying on essentially Bulgarian“ cultural and material belongings." 30 The first emergence of The Turks" in the novel happens in the words of Grandma Ivannitsa, when she rocks gently the youngest child in her arms for sleeping. In the dialogue between Ivanitsa and his son Marko, a clear Turkish image is presented:

Hush, darling, hush, or the Turks will come and carry you off,"... - Mother," he (Marko) said, why do you always terrify them with the Turks? You'll only make cowards of them." Well, well, that's my way," said the grandmother. Why shouldn't I? Aren't the Turks terrible enough? I've seen em now for over sixty years, and they'll be just the same when I die." Ah! Grandma," said little Petr, when I and brother Vassili and brother Ghiorghi grow up, we'll take our scythes and kill all the Turks." Won't you leave a single one of them, dear?" (4)

This is a completely natural way to express the national hatred towards the Turks, who are identified with the Big bad wolf" image in fairy tales. The terrible Turks can make children obey their parents and grandparents, as well as harboring this animosity in their whole life. Fear and hatred of the Turks are passed down from the old generations to the young, becoming a tradition of the Bulgarians of the time.

There is no groundless animosity. Early in Chapter Two The Storm", the barbarian image of the hostile Other becomes deeply ingrained in reader's mind. The two armed Turks, bloodthirsty Yemeksiz Pehlivan and his companion, nearly brutally rape the thirteen-year-old girl Marika in front of her father, but for the rescue of Kralich (Ognyanov). The Turks are portrayed as greedy and evil - -almost colourless eyes twinkled with evil cunning", with a face of bestial expression, in which the 
lowest animal instincts and ferocity were apparent", -east eager glances at the sleeping girl" (11-12). In this episode, the names of the two perpetrators are seldom mentioned, being almost replaced by the Turks". The brutality of the Turks is portrayed to the utmost, which reflects the evil image of the Turkish Other in the eyes of the Bulgarians.

The most direct expression of the hatred to the Turks is the way of Mouncho, who goes to the two Turks' burial place every day, stone in hand, to fling at the grave of the Turks so much so that quite a heap had by this time been raised there (89)."

In addition to this, the manner in which Vazov portrays the villainous Turks provides a vital contrast with the good Bulgarians. The Turkish bey ${ }^{31}$ is depicted as a ridiculous, indulgent and indolent fool. The first instance of this is when it is revealed that Sokolov has been having an affair with the bey`s wife. By making the bey a cuckold, Vazov portrays him as impotent. Later, the bey is made out to be a buffoon when, after the schoolmasters' production, the people burst out into revolutionary song in front of him and he is none the wiser. Another example of comic incompetence on the part of the bey is when he and Stefchov attempt to translate a revolutionary letter. The image of the guy overly proud of his false interpretation is vividly revealed in pages. A final example of the bey's incompetence is that he is unable to gather any evidence about the revolutionary activities himself. He is forced to get his information from the traitorous Bulgarian Stefchov. The comic and incompetent Turkish governor satisfies the Bulgarians' mentality of Turkish-phobia, 
forming a complete Enemy Other in their mind.

In contrast to the Turkish image, the Russian Other is pursued and admire in this novel. Great expectation that warm the heart of Bulgarians has to do with Russia. For Chorbadji Marko it is no doubt that freedom will only come from there. In the same episode that Grandma Ivanitsa frightens children for sleeping with the Turks", Marko hurriedly changes the conversation to Russia: tell us something about Russia... Why, something about Ivan the Cruel, or Bonaparte when he burned Moscow, or - (5)". The preference to the story of the greatness of Russia delivers unconcealed joy to Marko, who cherishes sweet hopes in his mind that the moment of liberation (thanks to the assistance of the Russians) will come in the not too distant future. That is the gist of this work, as Edmund Gosse pointed out in his introduction, The whole story is the chronicle of one of those abortive attempts which were made throughout Bulgaria and Roumelia forty years ago, under the hope of help from Russia, to throw off the intolerable Turkish yoke of tyranny"32.

The favor for Russia finds extreme embodiment in the harmless idiot Mouncho. It is he who, unobserved, witnesses the burial of the two Turks killed by Ognyanov. For this reason, Mouncho idolizes Ognyanov and identifies him as Russian" -for him, heroic acts are all conducted by Russians:

At that moment Mouncho had stealthily approached; he stopped and fixed his eyes on Ognianoff $\mathrm{f}^{33}$. A strange smile played over his idiot's countenance. In that look, bereft of reason, could be read the mingled affection, fear, and surprise which Boicho $^{34}$ had awakened in his mind. Years before he had cursed Mohammad before an on-bashi ${ }^{35}$, who had beaten him till he lay senseless on the ground. From that time his obscured conscience had retained only one feeling, one thought - a terrible, demoniacal hatred of the Turks. He happened to witness the slaughter of the two ruffians in the mill and their burial afterwards, and had conceived an unbounded 
admiration and reverence for Ognianoff. This feeling amounted almost to worship. He called him the Russian for some inexplicable reason. The first night he had been terribly scared by confronting him on the verandah, but he had since become accustomed to Ognianoff's frequent visits to the monastery. He seemed fascinated by him - could not take his eyes off him, and regarded him as his protector. Whenever the servants teased him he would threaten them with the Russian. - - shall tell the Russian to kill you too," drawing his fingers across his throat. But nobody understood what he meant by these words, fortunately... (86).

The hatred toward the Turks and the love for the Russians are synchronously portrayed in this episode. Meanwhile, the writer comes straight to the point, explaining that the hatred has its root in the beat" of the Turks, while the love is for the protector". The images of both Others have been established in the mind of Mouncho, behind whom stands the Bulgarian nation. The mad behaviors of Mouncho are associated with the key metaphor in the novel - madness, embodied in the protest against the atrocities of the Turks, and the deep reverence for the victims:

When he (Mouncho) recognised the head of his beloved Russian", his eyes flashed with a fierce unreasoning rage, and he broke out into a colossal and appalling blasphemy against Mohammed.

They hanged him by the butcher's shop.

The idiot was the only man who had ventured to protest (301).

Vazov is good at expressing real and simple thoughts of the public through the words of the naive. Mouncho is a good example; another is Subka, the little daughter of Chorbadji Micho. She, in the annual examination, unintentionally, speaks out the innermost thoughts and feelings of ordinary Bulgarian:

Subka, can you tell me what Tsar it was that freed the Bulgarians from the Greek yoke?"

The Bulgarians were freed from the Turkish yoke by...", the child began erroneously.

No, no, Subka," cried her father. You're to tell us by what Tsar they were freed from the Greek yoke. We all know what Tsar is to free us from the Turkish yoke."

Chorbaji Micho's simple remark caused much laughter in the audience.

Subka cried eagerly: The Bulgarians were freed from the Greek yoke by Tsar Asen, but they will be freed from the Turkish yoke by Tsar Alexander of Russia." 
She had misunderstood her father's words.

Hatred of Turkish rule and expectation of Russia's salvation always go together in stark contrast. Each conscientious Bulgarian entertains the contradistinctive feeling, so that the ones, who are not good at disguise, blurt it out.

Another two examples of Russophilism are more subtle. One is concealed beneath the name of the characters. Chorbadji Marko Ivanov, portrayed as a good Bulgarian who finances the revolution with a cherry-tree canon and is sold out by traitors and arrested, and Ivan Kralich (the original name of Boicho Ognyanov) are integrated in patriotic activities. Not limited to this, their naming also highlights some integration. Marko Ivanov and Ivan Kralich are intertwined that the former's last name coincides with the latter's first name, and the name Ivan" implies the faith in Russia because in Bulgarian folk memory Dyado Ivan (Grandpa Ivan) is synonymous with Russia. The naming of the two positive characters shows the gratitude for Alexander the Liberator ${ }^{36}$ because of his victory in the Russo-Turkish War (1877-1878), thanks to which Bulgaria gained autonomy.

For the other subtle example, we should go back to the wall with six lithographs in Marko's house - Ermitazh, which refers to the State Hermitage Museum of Russia. For Marko, everything about Russia is gracious and worthy of being cherished. The paintings hung on the wall portray episodes of the Crimean War, among which the picture on the Siege of Silistra in $1852^{37}$ is worthwhile to be noted. This picture wears an inscription inaccurate in Wallachian - Resboiul Silistriei (Battle of Silistra), which has been corrected by someone wise with a translation in Bulgarian - Razboia in Silistria (Robbery of Silistra). The 
battle of Silistra was fought in 968 between the armies of Bulgaria and Kievan Rus and resulted in Rus' victory, whereas the Siege of Silistra took place during the Crimean War between Russia and the Ottoman Empire and ended in Russia's retreat forced by diplomatic pressure and the threat of military action by the Austrians. The change of one word in the inscription signifies the preference of the painting-owner, that is, he admires Russia's fight againt Turkey, avoiding any mentioning of the conflict between Bulgaria and Russia. And the last picture, which represented the Russian generals in the war, is an expression of Russophillism in a more obvious way. The way Grandma Ivanitsa calls the Russian generals - martyrs", and her pains-taking protection of this picture show the extensive respect of the ordinary Bulgarian people to Russia and its army. Another message, more latent and covert underneath the words, is Pope Stavri's assertion that the generals` legs had been cut off by the English cannon, which discloses the hostility of the Bulgarians to Britain due to its military aid to the Ottoman Turks. Contradictions between Ourselves and Enemies are deep-seated in the people's mind, taking for granted blames on their enemy and the friends of their enemy.

It is to be observed that the people in Bela Cherkva, despite placing hopes on Russia, are very conscious that they, the Bulgarians themselves, are the creator of the national destiny. When the people keep arguing on the question of who will be the terminator of the Turkish tyranny, the majority believe it will be Grandpa Ivan". While Chorbadji Micho, an enthusiastic Russophil, concludes: As I say, I think we will go ahead, and he (Grandpa Ivan) will follow us with sword and mace, until to St. 
Sofia!"38

The Other image of the Turks and that of the Russians run throughout the novel, without which the plot could not have gone further. The expressions of national sentiments -repressed or heated, pessimistic or optimistic, are closely associated with them. They help the Bulgarians to construct the Self' by identifying the -enemy Other" and friend Other".

To sum up, Under the Yoke shows the entire cosmos of the Bulgarian people, formulating their everyday-life views, describing philosophy of the enslaved people that reconciles them with the life. In this work, we see a nation with tolerance and defensiveness on one side, with heroism and passion on the other. Admittedly, flexibility and fickleness are not excluded. Essentially, by describing the numerous meetings and conversations, the theatrical in which various social groups participate and the home decorations, Vazov has shown us that milieu in which the everyday life run and in which the sturdy, constructive optimism of the Bulgarian spirit ripened, grew luxuriantly and dominated ${ }^{39}$.

In Under the Yoke, Ivan Vazov portrays the nation living under political, economic and social servitude for nearly five centuries. Still, the Bulgarians tenaciously clung to their cultural heritage - they have not lost their Slavic language, customs and traditions, nor their rich folklore - the dance and myth; nor have they forgotten their glorious past; nor importantly, have they given up their Orthodox Christian faith which preserves themselves from being assimilated by the Turks. They respect rather than abandon their traditions, treasuring their belonging to the 
lowly -aste" of the giaours", as the Turks called the Christians. Thus, they stand out and keep their nationality during the long Ottoman yoke.

In his novel Under the Yoke, Vazov utilizes themes of resisting the Ottoman yoke to construct the image of the non-Bulgarian Other as Muslim-Turkish. As Maria Todorova points out that Vazov's novel is evidence of the emerging interpretation of the Ottoman legacy which holds to the incompatibility between Christianity and Islam, as well as the that between the essentially nomadic civilization of the newcomers and the old urban and settled agrarian civilizations of the Balkans and the Near East (Todorova 1996, 46-47). It is obviously shown in the novel that the Bulgarians harbor a bitter hatred for the Turks in the mind. They eat, drink, truckle to the Turkish tyranny, but the hatred permeates the blood of everyone, old or young, wealthy or impoverished. This hatred is embodied in the intoxicated reactions to the upcoming revolt, but most importantly, in the conversations of everyday-life, in the education of children, and in the first reactions to terrible happenings. For example, when Kralich (Ognyanov), the stranger visitor, escapes to Marko's house and hides himself in darkness, Marko's first reaction is to cock his pistol, and cry loudly in Turkish,

Đon't stir, or else you're a dead man." He waited a moment with his finger on the trigger.

Gospodin ${ }^{40}$ Marko," whispered a voice.

Who's there?" asked Marko in Bulgarian.

Đon't be afraid; it's a friend." ...

Who are you?" asked Marko suspiciously as he lowered his pistol.

Marko shouts in Turkish at the intruder, cocking pistol at the same time. But hearing the Bulgarian makes him disarmed. Marko's instinctive action in this episode 
identifies both Self” and -ther". People‘s identities are marked by the language they use. Along with the faith mark, language serves the purpose of identifying Other and Self.

Vazov's attitude towards the other - ther" is much more friendly. The people in the novel talk about Russia in a tone of worship, decorate their houses with paintings depicting the events in Russian history, and regard the Russians as the saviour of Bulgaria. Even in the mind of the idiot and little girls, Russia takes the role of heroic and invincible liberator. This almost instinctive reaction indicates that the Bulgarians identify the Russians as friend, brother in common faith and similar culture. The deep mental dependence on Russia does not only come from the ethnic and cultural links between the two peoples; another crucial point is that, Russia is constantly at war with Turkey. Expecting the aid from the one who is fighting against the Enemy is undoubtedly logical for the people enslaved. These perceptions play an important role in the formation of the Bulgarian national identity and consolidation of the nation, not only in the literary work, but in real history.

Unfortunately, both Vazov and the Bulgarian people portrayed in his work developed a tendency to subordinate to the will and help of stronger nations, particularly that of Russia. The consequence of this voluntary subordination did not emerge until Bulgaria regained national autonomy.

\footnotetext{
${ }^{1}$ Discourses of Collective Identity in Central and Southeast Europe (1770-1945): National Romanticism - The Formation of National Movements, Budapest: Central European University Press,
} 
2006, p. 87.

2 See Krastyo Krastev: On Ivan Vazov, Bulgarian Criticism on Ivan Vazov, Sofia: Bulrarian Writer, 1988, p. 25-37.

${ }^{3}$ Cited in Elana's interview with Krastev on Aug. 17, 1905.

http://www.slovo.bg/showwork.php3?AuID=308\&WorkID=11389\&Level=2, accessed on Oct. 5, 2013.

${ }^{4}$ Criticism on Under the Yoke by Dr. V. Baldjiev, Sofia, 1896, http://litclub.com/library/kritika/baljiev/index.htm, March of 2003.

5 Malina Tonova: Myth of the heroic HOME in the novel Under the Yoke", Bulgarian Language and Literature (electronic version), 2005, No. 1, http://liternet.bg/publish11/m tonova/mitologizaciia.htm, accessed on Sep. 21, 2013.

${ }^{6}$ Ibid.

7 The author himself was a member of the leadership of April Uprising.

${ }^{8}$ Discourses of Collective Identity in Central and Southeast Europe (1770-1945): National

Romanticism - The Formation of National Movements, 2006, p. 88.

9 Zahari Stoyanov: Preface, Bulgarian revolt 1870-1876: Narrative of Eyewitness.

http://www.slovo.bg/showwork.php3?AuID=149\&WorkID=3866\&Level=3, accessed on Oct. 3, 2013.

${ }_{10}$ Discourses of Collective Identity in Central and Southeast Europe (1770-1945): National

Romanticism - The Formation of National Movements, 2006, p. 89.

${ }^{11}$ Ibid.

12 Dr. Vassil Baldjiev made comments alike in his book Criticism on Under the Yoke (1896). Such comments can be found in The Ideology of the Nation: Speeches on Vazov (1994) by Inna Peleva, the article Under the Yoke - Metalanguage Fluctuation" published in journal Literature (No. 1, 1994).

${ }^{13}$ Milena Tsaneva: On National Epic Under the Yoke: Genre and Compositional Characteristics and the Ideological and Emotional Pathos, http://myschoolbel.info/Temil1_Vazov.html, accessed on Sep. 23, 2013.

${ }_{15}$ Ivan Vazov: Collected Works, Vol. XII, Sofia: Bulgarian writer, 1956, p. 16.

15 Under the Yoke - Encyclopedia of the Bulgarian Life in the National Revival", Bulgarian

Language and Literature, www.myschoolbel.info, accessed on Sep. 22, 2013.

16 As Todor Влайков ‘s novel Grandfather’s Honorable Grandson (1889).

${ }^{17}$ Also know as feon".

18 This explanation on Orthodox eikonographia owes to Hieromonk [now Bishop] Auxentios in his presentation to a graduate seminar in advanced iconography at the Graduate Theological Union, Berkeley, in the spring semester 1987. http://orthodoxinfo.com/general/orth icon.aspx, accessed on Sept. 26, 2013.

19 In another work of Ivan Vazov Bulgarian, the author makes the statement.

20 The English translation of 1912 by William Heinemann (London) translates the word by its general meaning, neglecting the connotation which the Bulgarian word conveys. In contrast to this, the Chinese translation of 1982 by People's Literature Publishing House (Beijing) makes improvement, which gives the transliteration with a footnote for explaining what it refers to.

${ }^{21}$ This is a museum of art and culture in Saint Petersburg. It was founded in 1764 by Catherine the Great and has been open to the public since 1852 .

${ }^{22}$ A detailed interpretation on Ermitazh will follow in the section The two Others in the work" of this chapter.

${ }^{23}$ Milena Tsaneva: On National Epic Under the Yoke: Genre and Compositional Characteristics and the Ideological and Emotional Pathos, http://myschoolbel.info/Temil1 Vazov.html, accessed on Sep. 23, 2013.

${ }^{24}$ The author's words. See Under the Yoke, p. 90.

${ }^{25}$ Spencer S. Stith: A Comparative Study of Post-Ottoman Political Influences on Bulgarian National Identity Construction and Conflict, 2008, p. 40.

26

27 These are the first two lines of a patriotic song by M. Stamboloff, the famous Prime Minister of

Bulgaria. - The translator's note.

${ }^{28}$ The national dance of Bulgaria.

29 Discourses of Collective Identity in Central and Southeast Europe (1770-1945): National Romanticism - The Formation of National Movements, Budapest: Central European University Press, 
2006, p. 89.

${ }^{30}$ Mary Neuburger: The Orient Within: Muslim Minorities and the Negotiation of Nationhood in Modern Bulgaria. Ithaca, NY: Cornell University Press, 2004, p. 38.

31 This is a title for chieftain in the Ottoman Turkey, traditionally applied to the provincial governors or the leaders of small trible groups.

32 Edmund Gosse: Introduction, Under the Yoke, London: William Heinemann, 1912, p. v.

33 Another translation of - Đgnyanov".

${ }^{34}$ The firstname of Ognyanov.

35 Lit. decurion, a corporal of Zapties (police).

36 Alexander II of Russia, he became known as Alexander the Liberatore for his most important achievement of the emancipation of serfs in 1861. In Bulgaria, this label was associated mostly with his victory in the Russo-Turkish War 1877-1878.

${ }^{37}$ The Siege of Silistra took place during the Danube campaign of the Crimean War in 1854. The author of this novel might get this fact wrong.

${ }^{38}$ For unknown reason, the translator of the English version (1912) missed some chapters of the original, including this chapter - In Ganko's Cafe". This paragraph is quoted from the original Bulgarian version (1956), translated by the author.

39 Peter Dinekov: Foreword to Under the Yoke, 2003.

${ }^{40}$ Gospodin is Mr. in Bulgarian. 


\section{CHAPTER 6 SUMMARY AND CONCLUSION}

Nationalism, in a widely accepted sense, is referred to as a theory of political legitimacy" or as an endeavor to endow culture with its own political roof." most prominent manifestation is the search for a national identity, which -derives from the fact that nationalism locates the source of individual identity within a people, which is seen as the bearer of sovereignty, the central object of loyalty, and the basis of collective solidarity." ${ }^{2}$ In the previous chapters, I have proved that Bulgarian national identity is not fixed or resistant to change, but fluid. It changes according to how the people (particularly the national elites) evaluate the domestic and international circumstances at certain time and place.

\subsection{The fluidity of Bulgarian national identity}

Prior to the Crimean War, Bulgarian national liberation movement focused mainly in the cultural area peacefully. During this period, the Bulgarian bourgeois rose and created the unique Bulgarian national culture. Their national activists promoted the ideals of the Orthodox faith, the Bulgarian language and the Slavic origin, regarding them as the true and only determinants of their national identity. All these characterized the national revival at that time and independence from Ottoman domination was the ultimate goal. Among these cultural needs, the insistence on 
using Bulgarian as their only language in communication and schooling was of enormous importance. The establishment of an autonomous Bulgarian church free from the Greek ecclesiastical domination was perhaps a goal of even greater importance and weight ${ }^{3}$. The Bulgarian Orthodox clergyman Paisii Hilendarski, in his Slavonic-Bulgarian History, educated his countrymen to use their own language and get to know their history. His most famous sentence -Why are you ashamed to call yourself Bulgarian and why do not you read and speak in your own language" stimulated and strengthened the Bulgarian national consciousness and instilled the minds of the Bulgarians with self-confidence and national pride ${ }^{5}$, which enabled the Bulgarians to differentiate themselves from other ethnic groups in the region, rather than being Hellenized and Turkized. As Todorova interprets the Ottoman legacy in the Balkans, @ttoman becomes synonymous with Islamic or Turkish (and to a lesser extent Arabic and Persian) influences in different spheres, usually subsumed under the heading Oriental elements." ${ }^{6}$ They also bonded with the neighboring Balkan populations and formed a relationship based on shared beliefs and particularly experiences of being dominated by the Turks - their common -enemy" Other.

It is important to recall the historical background of the five-century Ottoman rule over the land that encompassed contemporary Bulgaria. The Ottoman legacy provided the core identity building blocks which were utilized by successive nationalist campaigns to pursue their deliberate agendas of either homogenization or heterogeneity within the Bulgarian geographic territory. The leaders of the Bulgarian national revival movement started the homogenization ball rolling by rejecting the 
non-Bulgarian identity to further their political goals of autonomy, which was achieved in 1878 .

During the process of active opposition to the foreign Ottoman domination throughout the territory, the Bulgarians highly promoted their common faith, culture and language origin with the Russians and the Balkan Slavs, identifying them as Friends due to their common goal of paralyzing the declining Ottoman Empire. This manifested the proposition of the Bulgarian national identification at that time, i.e., the perception of homogeneity or alikeness. Such proposition helped the Bulgarians to define their nation and regard the ones like themselves as friends. The homogeneity mattered in forming the collective identity ${ }^{7}$. More importantly, the common fate of the Balkan people, constituted by the third party - the Ottoman Empire, was the objective condition for the formation of the collective identity of the Bulgarians. As Wendt illustrates the cases where an aggressor threatens the survival of two states simultaneously, it is natural for the defenders to share the common fate and work together on the principle that the enemy of my enemy is my friend". The Turkish tyranny, unwittingly, created the objective condition for forming a Balkan We among the conquered Balkan nations.

At the same time, Russia was identified by the Bulgarians as big brother" or father" because of its cultural closeness with Bulgaria and its political and military influence in the region. As in Ivan Vazov's work Under the Yoke, the Russians were called -Grandpa Ivan", which transcended the sense of friend". For the Bulgarians, Russia was a powerful reliance in their noble national cause. 
By identifying the Ottomans as the enemy Other and the Russians and other Balkan Slavs as the friends Others, the Bulgarians initially constructed their national identity, defining themselves as a member of the Balkan Slavs and enjoying common faith and culture with Russia and other Slavic ethnic groups and common goal of overthrowing the Ottoman tyranny. Influenced by this identification, the leaders of national revolutions confirmed their political demands according to their national interests. They participated in the liberation movements of other Balkan peoples, attempted to force the Ottoman Porte to enact further reforms while initiating secret negotiations among the Balkan nations, especially the Serbs, for the creation of a Balkan federation $^{8}$.

Admittedly, the imagined national identity strengthened the national consciousness and confidence of the Bulgarians, orienting themselves in the resistance against the Turks. But the national interests and political claims established consequently suffered difficulties of execution. Each of Bulgaria's neighbors had made substantial gains toward the realization of their respective national goals and saw Bulgaria as a rival in their territorial and other aspirations ${ }^{9}$. And for the Bulgarian national elites, Russia was a highly suspect object due to its strategic ambition in the Balkan region. As Wendt explains, homogenization is not a sufficient condition for collective identity formation ${ }^{10}$, nor is interdependence or common fate. What is worse, as these factors increase, the actors become more vulnerable to each other and thus have more objective reason for insecurity... At the limit this means assuming the worst about others lest trusting them gets you stabbed in the back, but 
even states who think in terms of probabilities rather than worst-case possibilities will tend to discount the long-term benefits of cooperation, minimize their dependency on others, and worry about relative gains - all of which make it difficult to engage in the prosocial practices necessary to forge collective identities"11. The distrust prevented the Balkan nations who faced a common threat from working together, permitting the Ottoman conquerors to divide and rule them. Meanwhile, motivated by the fear of being exploited by Russia and the distrust of Russia's self-restraint, the Bulgarian national elites began to redefine the boundaries of Self and Other, and the structure changed accordingly. From the responses of journalisms, the Bulgarian elites, Georgi Rakovski, Lyuben Karavelov and etc., carefully restrained their trust in Russia for fear of falling into the bondage of Russia after overthrowing the Ottoman rule. If we judge from the linguistic aspect, the distrust and even hostility to Russia became more apparent. The claims for purifying the language by substituting the loanwords from the Russian with words from the vernacular highlighted the restrained trust of the Bulgarian nationalists in Russia and Russian values.

After the Crimean War, the revival process swept the Bulgarian area rapidly. The newly-formed Bulgarian nation expressed its historical demands and created its political ideas in the resistance against the Ottoman rule. Many national revolutionaries maintained the union of Balkan Christians because of the weakness of the inner strength. Moreover, due to the common fate which linked the Balkan peoples for centuries, Bulgarian national activists participated in Serbian and Greek 
uprisings. For them, all nations and countries against Turkey were friends of Bulgaria. Another reason why the Bulgarian nationalists preferred to allying with the Balkans was that Bulgaria's self-armed action was still impossible in this period. But against their will, the Bulgarian nationalists were viewed for the most part as convenient tools in the common cause to overthrow the Ottoman hegemony over the Peninsula. The Bulgarians found it difficult to unite all parties on the issue of national liberation. Throughout the early nineteenth century there were individuals participating in foreign liberation uprisings initiated by their neighbors, but no group or movement emerged which had the support of a significant number of its compatriots ${ }^{12}$.

Baffled by the Balkan nationalisms, the structure of the Bulgarian national identification began to change. The political idea of advancing the Bulgarian liberation movement turned to be independent revolutionary action instead of forming a confederation of the Balkan countries. Therefore, the friends in the Balkans became rivals, with whom the Bulgarian nationalists competed for the support of the Great Powers.

The failure of the April Uprising prickled the Bulgarians. They doubted the capability to liberate the nation by their own strength. To achieve its national ends, Bulgaria needed patrons with lasting strength. With this in mind, the Bulgarians participated in the military actions with the Russian army in the course of Russo-Turkish War 1877-1878.

Here we need to distinguish the resort of Bulgaria to Russia in the late 1870s from its reliance on the Slavic groups in the early stage of the National Revival. In 
the early stage, when the Bulgarian national identity was not completely formed, the reliance on the external Slavic and Orthodox groups represented a sense of kinship. While in the late 1870 s, the Bulgarians with a consolidated national identity chose to use the possible forces to achieve their national goal. Taking the international and domestic situation into account, particularly after the unsuccessful April Uprising, the Bulgarian national activists had to resort to the Russians who could also benefit from the liberation of Bulgaria. In this case, the concern of the Bulgarians was whether the liberation would be accomplished, rather than who the liberator would be.

As a result of the Russo-Turkish War 1877-1878, the national autonomy brought to the Bulgarians immeasurable joy; meanwhile, they felt frustrated by the outcome of the Russo-Turkish War which failed to settle the Bulgarian Question according to the historical and national needs of the Bulgarian community. The decision of the Treaty of Berlin against Bulgaria fragmented the newly formed nation into parts, retarding the process of its further consolidation and fueling the appetite of the Great Powers to compete for interests in the country ${ }^{13}$. More tragically, instead of creating a democratic republic, Bulgaria was converted into a vassal principality, a toy in the hands of the Great Powers.

Another political and psychological consequence of the Treaty of Berlin was the discontent in the Bulgarian community to Russia for the lost territories and Russia's actural control over Bulgaria ${ }^{14}$. The bourgeois elites, who stood out in the nation turned to different Great Powers to achieve as many national interests as possible and try to restrain the influence of Russia upon the newly established Bulgarian state at 
the same time. But, in fact, they were made use of by the big powers in competing to control the Balkan region. Keeping distance with Russia made the structure change again - Russia was no longer identified as a constantly reliable friend" and protector" of Bulgaria; on the contrary, it became a suspicious and even dangerous manipulator who was a potential enemy of the Bulgarian nation, as Lyuben Karavelov believed. This tendency among the Bulgarian nationalists became evident in the serious breach against Russia during the reign of Alexander of Battenberg (1879-1886). Alexander, as a young prince of modern Bulgaria after the emancipation, unified the Bulgarian nation against Russian domination and succeeded in solidifying the national sentiment ${ }^{15}$.

The structural change impelled the Bulgarian to reestablish their national identity. The Slavonic properties, which were highlighted in the early stage of the National Revival, increasingly gave way to a Bulgarian identity. In other words, when the Slavonic-Bulgarian identity was consolidated and helped the nation to achieve, if partly, their national interests, the nationalists began to seek the uniqueness of the Bulgarian nation and try to avoid being over-tied to the Slavic friend-Others.

The redefinition of the national identity could be substantiated in the linguistic efforts in the given time. In order to create a purer new Bulgarian language with fewer foreign elements, the Bulgarian purists fought against those elements which were no longer necessary in practice. They aimed to keep a healthy development of the language, rather than being interfered too much by any foreign language. The 
loanwords from foreign languages, including Slavic, had to be replaced by the native terms. As a result, the Church Slavonic language and its successor - the Russian were transformed from the weapon of defending the Slavicness into a factor hindering the language development.

From both the journalistic and linguistic aspects at that time, we have enough reason to claim that the Bulgarians restrained their trust in the Russian because of their fear of being exploited. I have examined the ambivalent attitude of the Bulgarian towards the Russian in the previous chapters, but I would like to quote again the words from Wendt to elaborate the cause of this attitude. Wendt views that at the limit this means assuming the worst about others lest trusting them gets you stabbed in the back, but even states who think in terms of probabilities rather than worst-case possibilities will tend to discount the long-term benefits of cooperation, minimize their dependency on others, and worry about relative gains"16. Wendt's analysis gives an excellent explanation to the interrelationship between Bulgaria and Russia - a small Balkan state and a Great Power.

\subsection{The identity of Russia in Bulgarian nationalism}

Russia's special and complicated identity represented in the Bulgarian Question played an irreplaceable role in the development of nationalism of the latter. Between the Bulgarian and the Russian, there was a bond of friendship due to the shared national properties; more importantly, Russia was also the enemy of the Ottoman Turkey because they constantly competed for territories. Therefore, as we see in the 
early stages of the Bulgarian National Revival, Russia's involvement, in either the cultural or the political area, helped the enslaved Bulgarian to construct the national identity and establish their nationhood. With the exposure of Russia's ambitions for the Balkan region, the Bulgarian national elites began to restrain their trust in and the reliance on Russia for fear of being engulfed. The positive role of Russia in the mind of the Bulgarians was replaced by the potential danger of Russia, physically and psychologically. The solution to the problem of trust is external constraint by a third party $^{17}$. Bulgaria, in this case, resorted to other Great Powers which were strong enough to constrain the influence of Russia in the Balkan region. This might after all be accepted as a good solution. But the danger of the Bulgarian nationalism laid much in over-esteeming the influence of the Great Powers. In other words, the Bulgarian national elites overlooked the exploration of the domestic potential in the solution of the Bulgarian Question.

It is reasonable here to assume this is a fatal flaw of the Bulgarian nationalism. The national activists always preferred depending on certain Great Power or bloc of Great Powers to achieve some of their national interests and demands. Such dependency came partly from the lack of self-control due to the long-term Ottoman suppression. After a probe into the history of the Bulgarian nationalism, I believe that the dependency was a grave consequence of the unsuccessful April Uprising. Historians are used to highlighting the enormous importance of the uprising in enhancing the national liberating consciousness; moreover, they see the uprising as a motivator of the Ottoman collapse due to the publicity of the Turkish atrocities. 
Despite the positive aspect of the Uprising, its failure gave a severe blow to the rising national confidence of the Bulgarian who thought that their strength and their arms would be enough to guarantee the liberation and security of the nation. The April Uprising went against the revolutionary principle of Vasil Levski who had come to the most accurate and complete conclusions about the character, strategy and tactics of the national revolution. According to him, the Bulgarian revolution could have been accomplished only if the uprising was nationwide, organized and technically equipped well, and only if the internal strength was strong enough to destroy the military power of the Empire and to neutralize the Balkan nationalism. In addition to this, he also believed that the Bulgarian revolution might utilize external help only when the liberation movement was independent and less vulnerable to foreign manipulation $^{18}$. But in practice, the leaders rushed into the uprising without any careful plan, resulting in a disastrous defeat. Despite of this painful experience in their struggle, the national elites, in the actions thereafter, made less effort to overcome the weakness of the Bulgarian revolution - inadequate preparation and betrayal but turned to the Great Power for help instead. It can be seen from the adjustment of the revolutionary tactics after the April Uprising that the confidence crisis in the self-liberating strength led the Bulgarian liberation movement to complete reliance on the external forces. The danger laid not in making use of the external strength to try to find a solution to the Bulgarian Question, but in forming a kind of national mentality that the Bulgarian are impotent to rescue their own nation at stake. 
The lack of confidence in seizing the fate of Self led Bulgaria to national catastrophes in many cases. In World War I, the government of Vasil Radoslavov aligned Bulgaria with Germany and Austria-Hungary against Russia and their fellow Orthodox Christians (Serbia, Greece and Romania). During the first year of the $\mathrm{WWI}^{19}$, Bulgaria maintained neutrality trying to find out which of the two opposing sides could offer to settle its problem of territories lost to the other Balkan states in the Balkan Wars. At the same time the Central Powers were very generous of promises: if Bulgaria chose to participate on their side, it would receive all the territories it wanted, including the bonus land which it had never claimed. By resorting to the Central Powers, Bulgaria became an ally of the Ottoman, Bulgaria's traditional enemy. In the case of WWII, likewise, hoping for the territorial gains without shedding a drop of blood, the Bulgarian government led by Bogdan Filov declared neutrality upon the outbreak of the War. The successful recovery of Southern Dobrudja ${ }^{20}$ in 1940 with the approval of all Great Powers fostered an illusion that the territorial problem could be solved without direct involvement in the War. Unlike the case in the WWI, the ruling circle seemed determined this time to observe which of the two sides would satisfy Bulgaria's territorial claims to the greatest degree. But as what had happened before, the Bulgarian were seemingly forced to join the fascist bloc in order to avoid the war with Germany and restore all of the lost territories. But when the war picture changed with the Germans failing to take Moscow at the end of 1941, the Bulgarian political circle abandoned the Axis and joined the Allies. 
Of course, we have to admit that it was the specific geopolitical position of Bulgaria that made everyone of the Great Powers force it to join the war. That was an objective factor. The subjective judgments made by the Bulgarian authority, in each case, determined the nation's fate. The Bulgarian political parties, simple associations of groups of people, lacked in principle and had the only aim to climb to Power so as to participate in sharing the spoils of war. The choice of succumbing to the stronger nations, unfortunately, brought to Bulgaria a fact that it was doomed to be utilized by new exploiters.

As a Great Power, to which the Bulgarian national elites often went, Russia played dual roles in the formation of the Bulgarian national identity and the consolidation of the Bulgarian nationalism. I would like to utilize the two opposing attitudes towards Russia after the Liberation of Bulgaria in 1878 to articulate its dual roles upon the Bulgarian nationalism.

The Treaty of San Stefano came about due to the Russian efforts. Paying gratitude to this, the majority of the Bulgarian viewed Russia not just as a Great Power but also as a liberator. In the following decades, the Bulgarian and their political leaders gradually divided into Russophile" and Russophobe" groups. The Russophile defended the idea that the Bulgarian should be forever grateful to the Russian for the liberation. The Russophobe were of the opinion that Russia had been pursuing nothing but its own imperial interests and accused it of unwillingness to protect the Bulgarian interests against the other Great Powers ${ }^{21}$.

The Russophile advocated the positive role of Russia in the Bulgarian 
nationalism. Both the ideology of Slavdom and Russia's support to the Bulgarian national liberation movement were of significance in the awakening of the Bulgarian national consciousness, the consolidation of the nation and the accomplishment of the national autonomy. In the aspect of culture, Russia enlightened the Bulgarian elites with translated books, lingusitic loanwords and education of the emigrates; at the same time, the common Orthodox faith, the Cyrillic alphabet and the Slavic traditions helped to construct the Bulgarian national identity, turning Russia into a big brother" or even father" of Bulgaria. From the perspect of politics, despite of Russia's selfish strategic consideration, it indeed played the role as a supporter, protector and liberator in the course of Bulgaria's fighting againt the Turkish rule. The strong evidence for this is the Liberation of Bulgaria in 1878 which was one of the achievements of the Russo-Turkish War 1877-1878.

The Russophobe‘s idea reflects the negative value of Russia's influence. Driven by their own political and diplomatic interests, Russia's Balkan strategy often showed contradictions on different issues of the Balkan, which was always counterproductive. Also due to Russia's inconsistent and indecisive diplomacy to the Balkan states, the conflicts among the Balkan nations were exacerbating, particularly on the issues related to the territorial division, which was a hidden danger to the subsequent ethnic contradictions. For Bulgaria, the egoistic Russia in the Balkan region was a great threat because the national needs of Bulgaria would always in danger of being sacrificed in the framework of Russia's broader strategy for the region. For fear of being wholly submerged by or sacrificed to the -big brother", Bulgaria was always 
ready to turn against its erstwhile fiberator". Looking up the historical materials and publications, we can see that the Bulgarians were often in an ambivalent state that they doubted the original intention of Russia's helping activities, and whether Russia would restrain itself as a liberator. This reflected two sides of the Russo-Bulgarian relationship - interdependent and homogeneous on one side, sensitive and vulnerable on the other. The ambivalent state created a sense of uncertainty and insecurity in Bulgarian nationalism.

\subsection{Is nationalism good or bad for Bulgaria?}

Then, is nationalism exactly good or bad for Bulgaria? This question is not at all simple. As I mentioned before, Hans Kohn, in his The Idea of Nation (1945), made the distinction between Western and Eastern nationalism, believing that If the Western nationalist idea - at least in its idealized form - stressed universalism, rationality, and self-transcendence, the Eastern stressed particular national identities,

an emotional connection to history, and development rather than transcendence."22 This distinction perpetuates notions of Western and Eastern nationalism and good" and bad"/-evil" nationalism.

Kohn's dichotomy approach is an attempt to separate the good nationalism from the bad by using geographical criteria. But when we probe into the Bulgarian nationalism, we find this dichotomy is fallacious and misleading for it disregarded the historical criteria and the true nature of nationalism in the aspect of both politics and culture. The differences in history have also divided nationalism within this 
geography. In the West, there were established legal codes, civil rights and other factors which served to unite those who shared these values into one group. While in the East, these values were still undeveloped since most of the Eastern (European) nations were still under the foreign rule without national autonomy. So when it became necessary to unite the masses on the path towards modernization, the national elites needed to resort to what they had already shared - language, tradition, religion, customs, etc. The uneven development of history put the West and the East in two social phases. The former pursued civil rights, the latter national rights. In spite of the different forms of nationalism, we have to admit that the nature of the Western and Eastern nationalism is equal in value. That is to say, when the elites of a nation realized that they were at disadvantage and needed to make progress in order to be made equal in the new civilization heralded by modernity ${ }^{23}$, nationalism got into the act.

The exercise of nationalism is the assertion of the political sovereignty of a community in the form of a nation-state. As Gellner pointed out, there is a relative congruence of a political unit and a high culture where a certain kind of homogeneity is necessary for a cohesive nation-state ${ }^{24}$. In the Bulgarian case, nationalism, in practice, was a long journey towards the Bulgarian nationhood and in the pursuit of the establishment of a Bulgarian nation-state. In other words, nationalism was used by the Bulgarian intellectual awakeners as a vehicle for mobilizing the mass, and thus nationalizing them. This process witnessed the birth of a new, reviving culture through education and inherited characteristics. From the perspective, nationalism, 
the road of the Bulgarians to modernity for the establishment of a nation-state, is one of the symbols of modernity ${ }^{25}$. This is what Kohn failed to recognize by leaving out the positive factor of the Eastern nationalism in his approach.

We, therefore, have to go beyond the distinction of good" and bad" to understand the nationalism in many aspects and different stages of development. Nationalism is not inherently good" or bad", or in other words, nationalism itself does not have either positive or negative value. Its value changes with the change of the context. As is shown above in the comparison of the Bulgarian nationalism and the Ottoman legacy, nationalism is assumed to be positive. But in the years after Bulgaria's Liberation in 1878, the Bulgarian nationalism had mixed effects, which is hardly to be defined simply as a positive or negative thing.

The nation's major international interest after its liberation, for those in the nationalist movement, was to recover the real Bulgaria" by the Treaty of San Stefano. As was mentioned above in Chapter One, the Great Powers were heavily involved in shaping the geographic boundaries of Bulgaria, regardless of its ethnic composition, and redrafted the San Stefano borders to the Treaty of Berlin borders. The partition of territories in the Balkan region by the Great Powers led to a wave of discontent in Bulgaria. The new Bulgarian state entered into life with a ready-made program of seeing their territories taken away and a burning sense of injustice given by the great powers ${ }^{26}$. Although this nation's interests were never met in the decades between Ottoman rule and Communist regime, it did not prevent the nationalists from seeking to get back the tost land" and recover Bulgaria's territory to what it looked 
like according to the Treaty of San Stefano.

The Bulgarian nationalists' claiming of territories involved the nation into the overwhelming trend among the Balkans - irredentism. The explanation for this usually was that most of the borders of the Balkan region were carved out by the treaties after the wars, and thus many Balkan states presented irredentist ideas to their neighbors. The irredentist expectation for restoring the so-called San Stefano territories led Bulgaria to the disastrous Second Balkan War ${ }^{27}$ and even World War $\mathrm{I}^{28}$, which was more devastating.

In a word, the Bulgarian nationalism played different roles in different historical periods. The emerging nineteenth-century nationalism liberated the nation from the Ottoman domination, which is a great embodiment of the good" aspect of the nationalism. While in the following phases, Bulgaria's call for national unification and irredentism cannot be simply categorized as bad" or fegative" nationalism. The Great Powers, for their own interests, made use of the then national and religious conflicts in the Balkan region to provoke fights among the ethnic groups, disintegrate the Balkan nationalist movement and redraft repeatedly the borders of the Balkan states. Bulgaira was one of the hapless victims of this exploitation. The attempts of the powers for competing in the Balkan region made the Balkan nationalism more complicated.

The Bulgarian case is especially relevant to understand the national identity construction in the Balkan region while keeping the possibility for various religions, languages, and ethnic groups to coexist peacefully in a heterogeneous environment. 
The Balkan nationalism, likewise, not only covers the Balkan region, but also involves a number of Great Powers in different periods. This is the uniqueness and heart of the Balkan nationalism.

In the Western conception, nationalism is a disease that afflicts the less developed nations. However, nationalism is not only an ideology leading to atrocities, xenophobia, and war; but also a fundamental aspect of the society, both domestic and international. I would call nationalism a process that defines, creates, and expresses the essential loyalty to the nation, and view the term nationalism in a neutral sense. As Herb and Kaplan say, while this process can take extreme forms and lead to violent aggression and the extermination of others, nationalism can also be benign and form the basis for peaceful coexistence"29.

\footnotetext{
${ }^{1}$ Ernest Gellner: Nations and Nationalism, Oxford: Basil Blackwell, 1984, p. 43.

${ }^{2}$ Liah Greenfeld: Nationalism, Five Roads to Modernity, Cambridge: Harvard University Press, 1992, p. 3.

Firkatian: The Forest Traveler: Georgi Stoikov Rakovski and Bulgarian Nationalism, 1996, p. 8.

${ }^{4}$ Paisii Hilendarski: Slavonic-Bulgarian History, Sofia: Damyan Yakov, 2006.

5 Tibor Iván Berend: History Derailed: Central and Eastern Europe in the Long Nineteenth Century, University of California Press, 2003, p. 76.

${ }^{6}$ Maria Todorova: Imagining the Balkans, New York, Oxford: Oxford University Press, 1997, p. 162-163.

${ }^{7}$ For Wendt, collective identity of a state means internalization of the Other in the Self to an extent where the Other and the Self are one (Refer to Wendt: Social Construction of International Society, Cambridge Studies in International Relations, Cambridge University Press, 2003, p. 305-306).

${ }^{8}$ D. K. Kosev: Russia, France and Bulgarian Liberation Movement 1860-1869, Sofia: BAN, 1978, p. 5 .

${ }_{9}$ Firkatian: The Forest Traveler: Georgi Stoikov Rakovski and Bulgarian Nationalism, 1996, p. 11.

${ }^{10}$ Wendt: Social Theory of International Politics, p.355.

11 Ibid, p. 348.

${ }^{12}$ Firkatian: The Forest Traveler: Georgi Stoikov Rakovski and Bulgarian Nationalism, 1996, p. 11.

${ }^{13}$ Georgieva \& Genchev: History of Bulgaria XV-XIX, 2006, p. 551.

${ }_{14}$ Evidence for this discontent will be found in Chapter IV, in which the public response to the Treaty of Berlin is to be interpreted.

15 Jelavich: Tsarist Russia and Balkan Nationalism: Russian Influence in the Internal Affairs of Bulgaria and Serbia, 1879-1886, 1958, p. 276.

16 Wendt: Social Theory of International Politics, 1999, p. 348.

${ }^{17}$ Ibid, p. 358.
} 
${ }_{18}^{18}$ Georgieva \& Genchev: History of Bulgaria XV-XIX, 2006, p. 537.

${ }^{19}$ I use Crampton's A Concise History of Bulgaria as the main secondary source to sketch the major events of the two World Wars.

${ }^{20}$ Southern Dobrudja became part of Romania since 1913 as a consequence of the Second Balkan War.

${ }^{21}$ This overview owes to Antonina Zhelyazkova in Part Bulgaria" of Nations and Nationalism: A Global Historical Overview. Vol. 2, edited by Herb, Guntram H., Kaplan, David H., 2008.

${ }^{22}$ See the summary of the classification in the Preface.

23 John Plamenatz: Fwo types of Nationalism" in Eugene Kamenka, ed. Nationalism: The Nature and Evolution of An Idea, Canberra, Australian National University Press, 1975.

${ }^{24}$ Ernes Gellner: Nations and Nationalism, Ithaca: Cornell University Press, p. 1.

${ }^{25}$ Barker defines modernity as a post-traditional, post-medieval historical period, one marked by the move from feudalism (or agrarianism) toward capitalism, industrialization, secularization, rationalization, the nation-state and its constituent institutions and forms of surveillance (Chris Barker: Cultural Studies: Theory and Practice, London: Sage, 2005, p. 444).

${ }^{26}$ R. J. Crampton: A Concise History of Bulgaria, Cambridge: Cambridge University Press, 2005, p. 85.

27 In the Second Balkan War in 1913, Bulgaria attached its erstwhile allies in the First Balkan War for its discontent with the partition of the spoils.

${ }^{28}$ In the aftermath of the Balkan Wars Bulgaria turned against Russia and joined the alliance of German Empire and Austria-Hungary in WWI, even though this meant becoming an ally of the Ottomans, Bulgaria's traditional enemy.

${ }^{29}$ Herb and Kaplan: Preface, Nations and Nationalism: A Global Historical Overview, Vol. 1, p. xi. 


\section{REFERENCES}

Aleksic, Tatjana. Ed. (2007) Mythistory and Narratives of the Nation in the Balkans. Newcastle: Combridge Scholars Publishing.

Alons, Gerry C. Predicting a State's Foreign Policy: State Preferences between Domestic and International Constraints". Foreign Policy Analysis. Vol. 3, No. 3, 2007. pp. 211-232.

Anderson, Benedict. (1983/1991) Imagined Communities: Reflections on the Origins and Spread of Nationalism. 1st and revised editions. London and New York: Verso.

Andreichin, Lyubomir. (1979) The role of Church-Slavonic language in the construction of modern Bulgarian literary language". Textbook on History of the Bulgarian Literary Language. Sofia.

---. (1986) From the History of our Language Development. Sofia: National Education. (Андрейчин, Л. 1986. Из историята на намето езиково строителство. София: Народна просвета.) http://www.promacedonia.org/la/index.html

---. (1968) An important moment in the development of the modern Bulgarian literary language”. Reports of Bulgarian Language Institute, 1968, 16, p. 517-520.

Angelov, B. Paisii Hilendarski and the Development of our Literary Language in the $18-19^{\text {th }}$ Century". Slavist. 1985. pp. 13-22.

Aretov, Nikolai. (2001) Bulgarian Revival and Europe. Sofia: Kralitsa Mab. (Аретов, Николай. 2001. Българското възраждане и Европа. София: Кралица Маб.)

Arnaudov, M. ed. (1952) Archive of G. S. Rakovski. Letters and Manuscripts of Rakovski I. Sofia: BAN. (Арнаудов, М. 1952. Архив на Георги Раковски.Писма и ръкописи на Раковски I. София: БАН.)

Atanosov, Bogdan. (2005) fntroduction to Under the Yoke". (Translated by 
Marguerite Alexieva, Theodora Atanasova). Sofia: PAX Publishing.

Atkinson, Carol. (2006) -Constructivist Implications of Material Power: Military Engagement and the Socialization of States, 1972-2000”. International Studies Quarterly. Vol. 50, No. 3, 2006. pp. 509-537.

Baldjiev, V. (1896) Criticism on "Under the Yoke”. Sofia: (Балджиев, В. 1896. Критика върху „Под игото”. .Sofia: Централна печатница на П. Калъчев.) http://litclub.com/library/kritika/baljiev/index.htm

Banac, Ivo. (1984) The national question in Yugoslavia: Origins, history, politics. Ithaca, N.Y.: Cornell University Press.

Barker, Chris. (2005) Cultural Studies: Theory and Practice. London: Sage.

Barnard, F. M. (1965). Herder's Social and Political Thought: from Enlightenment to Nationalism. Oxford: Clarendon Press.

Berberoglu, Berch. (2004). Nationalism and Ethnic Conflict: Class, State, and Nation in the Age of Globalization. Lanham, Boulder, New York, Toronto, Oxford: Rowman \& Littlefield Publishers, INC.

Berend, Tibor Iván. (2003) History Derailed: Central and Eastern Europe in the Long Nineteenth Century. University of California Press.

Billig, Michael. (1995) Banal Nationalism. Thousand Oaks, CA: Sage Publications.

Bodjilov, I. et al. (1993) History of Bulgaria. Sofia: Hristo Botev. (Божилов, И. и др. 1993. История на България. София: Христо Ботев.)

Bogorov, Ivan. (1859) -Subject of the Bulgarian language". Tsarigradski Newspaper.

Borisov, Borislav. (2009) The Language Circumstance and Language Policy in Bulgarian and Czekh in National Revival”. Bulgarian Speech. 15(3). pp. 59-66.

Bozdagloglu, Yucel. (2007) - Constructivism and Identity Formation: An Interactive Approach". Review of International Law and Politics. Vol. 3. No. 11, 2007. pp. 121-144.

Brass, P. (1974) Language, Religion and Politics in North India. Cambridge: Cambridge University Press.

Brehony, Kevin J. and Rassol, Naz. Ed. (1999) Nationalisms Old and New. New York: St. Martin's Press, INC.

Breuilly, John. (1993) Nationalism and the State. Chicago: University of Chicago 
Press.

Brown, David. (1998) Why is the Nation-State so Vulnerable to Ethnic Nationalism?". Nations and Nationalism. vol.4, no.1, 1998.

---. (2000) Contemporary Nationalism: Cicic, ethnocultural and multicultural politics. London and New York: Routledge.

Brubaker, Rogers. (1996) Nationalism Reframed. New York: Cambridge University Press.

---. (1998) -Myths and Misconceptions in the Study of Nationalism". in John A. Hall (ed.,) The State of the Nation. Cambridge: Cambridge University Press.

Calhoun, C. (1997) Nationalism. Minneapolis: University of Minnesota Press.

Cohler, A. M. (1970) Rousseau and Nationalism. New York: Basic Books, Inc.

Comrie, Bernard and Corbett, Greville G. (1993) The Slavonic Languages, London and New York: Routledge.

Copeland, Dale C. (2000) The Constructivist Challenge to Structural Realism". International Security. Vol. 25, No. 2, Fall 2000. pp. 187-212.

Crampton, R. J. (2005) A Concise History of Bulgaria. Cambridge: Cambridge University Press.

Dimitrov-Rudar, Peter. (2001) In Search of the Truth - About the Detachment of Hadji Dimitar and Stefan Karadjata. Sofia: Pensoft. (Петьр, Димитров-Рудар. 2001. В търсене на истината - за четата на Хаджи Димитьр и Стефан Караджата. София: Пенсофт.)

Dogan, Mattei. (1997) Nationalism in Europe: Decline in the West, Revival in the East". Nationalism and Ethnic Politics. Vol.3, No.3, 1997. pp. 66-85.

Dorev, Pancho. Ed. (1942) Documents for Bulgarian History: Documents from Turkish State Archives 1863-1909. Vol. IV. Sofia: Pridvorna Pechatnitsa. (Дорев, Панчо. (Подбрал). 1942. Документи за българската история, m. IV. Документи из турските държавни архиви 1863-1909. София: Придворна печатница.)

Enloe, C. Bananas, Beaches and Bases. (1989) Making Feminist Sense of International Politics. London: Pandora.

Firkatian, Mari A. (1996) The Forest Traveler: Georgi Stoikov Rakovski and Bulgarian Nationalism. New York: Peter Lang. 
Gallagher, Tom. (2001) Outcast Europe: The Balkans, 1789-1989 from the Ottomans to Milosevic. London: Routledge.

Gasparov, Boris. (2010) Speech, Memory, and Meaning: Intertextuality in Everyday Language. Walter de Gruyter.

Geary, Patrick. (2003) Myth of Nations. The Medieval Origins of Europe. Prinston Paperbacks.

Gellner, Ernest. (1983) Nations and Nationalism. Ithaca: Cornell University Press.

---. (1994) Encounters with Nationalism. Oxford: Blackwell Publishers.

---. (1997) Nationalism. New York: Weidenfeld \& Nicolson.

Genchev, Nikolai. (1987) Vasil Levski. Sofia: Military Press. (Генчев, Николай. 1987. Васил Левски. София: Военно издателство.)

Genov, Georgi. (2001) American Elias Riggs and his contribution to the Bulgarian National Revival. Historical Archives. Sofia. Issue 9-10. November 2000-May 2001. (Генов, Георги. „Американецът Илайъс Ригс и неговият принос към Българското възраждане”. )

Georgieva, Elena et al. (1989) History of Modern Bulgarian Literary Language. Sofia: BAN. (Георгиева, Елена и др. 1989. История на новобългарския книжовен език. София: БАН.)

Georgieva, Tsvetana \& Genchev, Nikolai. (2006) History of Bulgaria XV-XIX, Sofia: Anubis. (Георгиева, Цветана \& Генчев, Николай. 2006. История на България XV-XIX век, София: Издателска къща Анубис.)

Gewehr, Wesley. (1931) The Rise of Nationalism in the Balkans, 1800-1930. New York: Henry Holt and Company.

Gladstone, William (1876). The Bulgarian Horrors and the Question of Eas., London: J. Murray.

Glenny, Misha. (2000) The Balkans: Nationalism, War, and the Great Powers 1804-1999. New York: Penguin Books.

Gerov, Naiden. $(1911,1944)$ Naiden Gerov's Correspondence. Sofia: BAN. (Геров, Найден. 1911, 1914. Из архивата на Найден Геров. София: БАН.)

Greenfeld, Liah. (1992) Nationalism, Five Roads to Modernity. Cambridge: Harvard University Press. 
Handman, M. S. (1921) The Sentiment of Nationalism”. Political Science Quarterly, XXXVI.

Haralampiev, Ivan. (2012) On the History of Bulgarian Language up to the National Revival, Veliko Tyrnovo: Faber. (Харалампиев, Иван. 2012. Лекuии по история на българския книжовен език до Възраждането. Велико Търново: Фабер.)

Hastings, Adrian (1997). The construction of nationhood: ethnicity, religion, and nationalism. Cambridge: Cambridge University Press.

Hayes, Carlton J. H. (1931) The Historical Evolution of Modern Nationalism. New York: R.R. Smith, Inc.

---. (1941) Essays on Nationalism. New York: The Macmillan Company.

Henninger, Thomas. (1987) Balkanische Lexik im Schrifttum der Bulgarischen Viedergeburt. Neuried: Hieronymus.

Herb, Guntram H., Kaplan, David H. (Editors) (2008) Nations and Nationalism: A Global Historical Overview. Santa Barbara: ABC-CLIO.

Hilendarski, Paisii. (2006) Slavonic-Bulgarian History. Sofia: Damyan Yakov. (Хилендарски, Паисий. 2006. Славянобългарска история. София: Дамян Яков.)

Holland, Thomas Erskine. (1885) The European concert in the Eastern question: A Collection of Treaties and other Public Acts. The Clarendon Press. p. 335-348.

Hosch, Edgar. (1968). The Balkans: A Short History from Greek Times to the Present Day. New York: Crane, Russak \& Company, Inc.

Humboldt, W. (1971) Linguistic Variability and Intellectual Development. Coral Gables, Miami: University of Miami Press.

Hutchinson, John, Smith, Anthony D. (2000). Nationalism: critical concepts in political science. London: Routledge.

Ivanov, Lyubomir. (2007) Essential History of Bulgaria in Seven Pages. Sofia: BAN.

Ivanova-Mircheva, Dora. (1987) Issues on Bulgarian Literary Language until National Revival. Sofia: National Education. (Иванова-Мирчева, Дора. 1987. Въпроси на български книжовен език до Възраждането. София: Народна просвета.)

Jelavich, Barbara. (1983) History of the Balkans: Eighteenth and Nineteenth 
Centuries. Cambridge University Press.

---. (1991) Russia's Balkan Entanglements 1806-1914. London: Cambridge University Press.

Jelavich, Charles. (1958). Tsarist Russia and Balkan Nationalism: Russian Influence in the Internal Affairs of Bulgaria and Serbia, 1879-1886. Berkeley and Los Angles: University of California Press.

Jelavich, Charles. Ed. (1963). The Balkans in Transition: Essays on the Development of Balkan Life and Politics since the Eighteenth Century. Berkeley and Los Angeles: University of California Press.

Karavelov, Lyuben. (2003) Freedom and Independence. Edited by Granitski, Ivan and Anchev, Panko. Sofia: Zaharii Stojanov. (Каравелов, Любен .2003. Свобода и независимост. Под общата редакция на Иван Гранитски и Панко Анчев. София: Захарий Стоянов.)

Kazhdan, Alexander P. (1991). The Oxford Dictionary of Byzantium. New York: Oxford University Press.

Kesiakov, B. (1926). Contributions to the Diplomatic History of Bulgaria, 1878-1925. Sofia. (Кесяков, Б. 1926. Принос към дипломатическата история на България 1878-1925. София.)

Kohn, Hans. (1944). The Idea of Nationalism: A Study in Its Origins and Background. New York: The Macmillan Company.

---. (1965) Nationalism: Its Meaning and History. New York: Van Nostrand Reinhold Company.

---. (1953) Pan-Slavism: Its History and Ideology. New York: Vintage Books.

Konev, Iliya (1983) Bulgarian Revival and Education. Vol. I. Sofia: BAN. (Конев, Илия. 1983. Българското възраждане и Просвещението. т. I. София: БАН.)

Kosev, D. K. (1978) Russia, France and Bulgarian Liberation Movement 1860-1869. Sofia: BAN. (Косев, Д. К. 1978. Русия, Франщия и Българското освободително движение 1860-1869. София: БАН.)

Krasner, Stephen D. (1999). Sovereignty: Organized Hypocrisy. Princeton University Press.

Lang, David Marshall. (1976) The Bulgarians: from Pagan Times to the Ottoman Conquest. Westview Press. 1976. 
Lantz, Kenneth. (2004). The Dostoevsky Encyclopedia. Greenwood Publishing Group.

Lazarov, Ivan et al. (1993) Short History of the Bulgarian Nation. Sofia: National Education. (Лазаров, Иван и др. 1993. Кратка история на Българския народ, София: Народна просвета.)

Lendvai, Paul. (1969). Eagles in Cobwebs: Nationalism and Communism in the Balkans. New York: Doubleday \& Company, INC.

Lerski, George J. (1996) Historical Dictionary of Poland, 966-1945, Westport: Greenwood Press.

Lukić, Sveta. (1972) Contemporary Yugoslav Literature: A Sociopolitical Approach. Urbana: University of Illinois Press.

Ma, Xipu. (2011) The History of Bulgaria. Beijing: China Social Sciences Press.（马 细谱: 《保加利亚史》, 北京: 中国社会科学出版社, 2011 年。)

MacDermott, Marcia. (1962) A History of Bulgaria, 1393-1885. Allen and Unwin.

MacKenzie, David. (1967). The Serbs and Russian Pan-Slavism 1875-1878. Itbaca, New York: Cornell University Press.

Makinda, Samuel. (2000) Reading and Writing International Relations". Australian Journal of International Affairs. Vol. 54, No. 3, 2000. pp. 389-401.

Martyn, David. (1997) Borrowed Fatherland: Nationalism and Language Purism in Fichte's Addresses to the German Nation”. Germanic Review. 72.4, 1997. pp. 303-315.

Manning, C. A. and Smal-Stocki, R. (1974). The History of Bulgarian Literature. Westport: Greenwood Press. (Originally published in 1960 by Bookman Associates, New York)

Mazis, J. A. (2004). The Greeks of Odessa: Diaspora Leadership in Late Imperial Russia. New York: Columbia University Press.

Meininger, Thomas A. (1974) The Formation of a Nationalist Bulgarian Intelligentsia, 1835-1878. University of Wisconsin-Madison.

Menze E. A. and Menges K. (1992). Johann Gottfried Herder: Selected Early Works 1764-1767 Addresses, Essays, and Drafts; Fragments on Recent German Literature. University Park, Pennsylvania: The Pennsylvania State University Press. 
Minkov, Tsvetan. (1929/2003) Ivan Vazov". Library “Bulgarian writer”. Vol. IV. Ed. by A. Vacheva. Varna: Liternet. (Минков, Цветан. 1929/2003. „Иван Вазов”. Библиотека "Български писатели. T. IV. Под ред. на А. Вачева. Варна: LiterNet.) http://liternet.bg/publish10/cminkov/vazov.htm

Mowat, R. B. (1915) Select Treaties and Documents to Illustrate the Development of the Modern European States-System, Oxford: Oxford University Press. 79-83.

Namier, Lewis B. (1963) Vanished Supremacies: Essays on European History, 1812-1918. New York and Evanston: The Academy Library Harper \& Row, Publishers.

Neuburger, Mary. (2004). The Orient Within: Muslim Minorities and the Negotiation of Nationhood in Modern Bulgaria. Ithaca, NY: Cornell University Press.

Norris, D. A. (1999). In the Wake of the Balkan Myth: Questions of Identity and Modernity. New York: St. Martin's Press.

Oakes, Leigh. (2001) Language and National Identity: Comparing France and Sweden. (in the series of Impact: Studies in Language and Society, Vol. 13). Amsterdam: John Benjamins Publishing.

Özkırıml1, Umut. (2000) Theories of Nationalism: A Critical Introduction. New York: St. Martin's Press.

Penkov, Sava. (1985) Treaty of Berlin and the Balkans. Sofia. (Пенков, Сава. 1985. Берлинският договор и Балканите. София.)

Petrovich, Michael Boro. (1956) The Emergence of Russian Pan-Slavism, 1856-1870. New York: Columbia University Press.

Plamenatz, John. (1975) Two types of Nationalism". in Eugene Kamenka (ed.) Nationalism: The Nature and Evolution of An Idea. Canberra: Australian National University Press. 1975.

Prousis, T. C. (1994) Russian Society and the Greek Revolution. DeKalb: Northern Illinois University.

Raoev, Ivan Nikolov. (1996) Encyclopedia of Bulgarian National Revival Literature, Abagar.

Riasanovsky, N. V. (1993) A History of Russia. New York, Oxford: Oxford University Press.

Rocher, Rudolf. (1937) Nationalism and Culture. Los Angeles: Rocker Publications Committee. 
Romanski, Stojan. Ed. (1951, 1953) Documents for New Bulgarian History: Documents from Vienna State Archives 1830-1877. Sofia: BAN. (Романски, Стоян. (Подбрал). 1951, 1953. Документи за новата история на българския народ из виенските държавни архиви 1830-1877. София: БАН.)

Roudometof, Victor. (2001) Nationalism, Globalization, and Orthodoxy: The Social Origins of Ethnic Conflict in the Balkans. Westport: Greenwood Press.

Rousseau, J-J. (1985) The Government of Poland. Translated by Kendall, Willmoore. Indianapolis: Hackett Publishing.

Rumyana Bavlova. (1979) Bulgarian-Russian and Russian-Bulgarian Linguistic Ties (in Russian). Sofia: National Education Press.

Rusinow, Dennison. Stokes, Gale (Ed.) (2008). Oblique Insights and Observations. Pittsburgh: University of Pittsburgh Press.

Safra, Jacob E. (Chair of the Board) (2002) The New Encyclopaedia Britannica (15th edition) Chicago: Encyclopaedia Britannica [2001].

Schevill, Ferdninand. (1966) History of the Balkan Peninsula. New York: Frederick Ungar Publishing Inc.

Schnee, Walter. (2001) Nationalism: A Review of the Literature. Journal of Political and Military Sociology 2001, Vol. 29 (Summer): 1-18.

Scholes, Robert. (1982) Semiotics and Interpretation. New Haven and London: Yale University Press.

Seton-Watson, R. W. (2010) The Rise of Nationality in the Balkans. E.P. Dutton.

Seton-Watson, Hugh. (1977) Nations and States. An Enquiry into the Origins of Nations and the Politics of Nationalism. Boulder: Westview Press.

Shaw, Stanford J. (1976) History of the Ottoman Empire and Modern Turkey Volume I: Empire of the Gazis: The Rise and Decline of the Ottoman Empire, 1280-1808. London: Cambridge University Press.

Shishmanov, Ivan. (1900) Eritical Review of the Origins of Proto-Bulgarians from Language Perspective and Etymology of the Name Bulgarian”. Collection of Folklore. Vol. XVI-XVII. pp. 500-754. (Шишманов, Иван. 1900 „Критически преглед на въпроса за произхода на прабългарите от езиково гледище и етимологията на името българин”. Сборник за народни умотворения. кн. XVI-XVII. 1900. c. 500-754.)

---. (1930. new edition 1976) Ivan Vazov: Memories and Documents. Шишманов, 
Иван. (1930. доп. изд. 1976) Иван Вазов. Спомени и документи.

Skendi, S. (1980). Balkan Cultural Studies. New York: East European Monographs, Boulder Distributed by Columbia University Press.

---. (1980). Hanguage as a factor of national identity in the Balkans in the 19th century". Balkan Cultural Studies. New York: East European Monographs. Boulder Distributed by Columbia University Press.

Smith, Anthony. (1983) (2nd edition) Theories of Nationalsim. New York: Holmes \& Meier.

---. (1986) The Ethnic Origins of Nations. Oxford: Blackwell.

---. (1991) National Identity. London: Penguin Books.

---. (1992) - National Identity and the Idea of European Unity.” International Affairs Vol. 68, No. 1 (Jan., 1992), p. 55-76.

---. (1994) Gastronomy or geology? The role of nationalism in the reconstruction of nations. Nations and Nationalism 1. pp. 3-23.

--- (1998) Nationalism and Modernism: a Critical Survey of Recent Theories of Nations and Nationalism. London: Routledge.

Snyder, Louis L. (1968) The New Nationalism. Ithaca, N.Y.: Cornell University Press.

Snyder, T. (1997) Kazimierz Kelles-Krauz (1872-1905): A Pioneering Scholar of Modern Nationalism', Nations and Nationalism, 3(2), 231-250.

Spolsky, B. (1999). Second-language learning”. In Handbook of language and ethnic identity edited by J. Fishman. Oxford: Oxford University Press. pp. 181-192.

Stamatov, Georgi. (2003) Under the Yoke - From the Life of Bulgarians Between the Romantic and Philistine". Bulgarian Language and Literature. 2003, Issue 4. (Стаматов, Георги. „Под игото” - Из живота на българите между романтичното и еснафското. Български език и литература. 2003, бр. 4.)

Stavrianos, L. S. (2000) The Balkans since 1453. New York: New York University Press.

Stith, Spencer S. (2008) A Comparative Study of Post-Ottoman Political Influences on Bulgarian National Identity Construction and Conflict. Degree of M.A. Graduate Faculty of the University of Kansas. 
Stojanović, Mihailo D. (1939) The Great Power and the Balkans, 1875-1878. Cambridge: University Press. (Reprinted by John Dickens \& Co. Ltd, Northampton.)

Stojanov, Z. (1946) Vasil Levski. Traces of his Life. Sofia. (Стоянов, 3. 1946. Васил Левски. Черти из живота му. София.)

Stokes, Gale. Ed. (1984) Nationalism in the Balkans: An Annotated Bibliography. New York: Garland.

Sugar, Peter \& Lederer, Ivo. (1969) Nationalism in Eastern Europe. Seattle: University of Washington Press.

Sugar, Peter F. Ed. (1995). Eastern European Nationalism in the Twentieth Century. Washington, DC: The American University Press.

Sumner, B. H. (1962) Russia and the Balkans 1870-1880. Hamden, London: Archon.

Sussex, R. and Eade, J. C. Ed. (1985). Culture and Nationalism in Nineteenth-century Eastern Europe. Columbus: Slavica Publishers, Inc.

Thomson, F. J. (1999) The Reception of Byzantine Culture in Mediaeval Russia. Aldershot: Ashgate.

Todorov, Nikolai. (1968) Bulgaria: historical and geographical outline. Sofia.

Todorova, Maria. (1995) The Course and Discourses of Bulgarian Nationalism". Eastern European Nationalism in the Twentieth Century. Washington, DC: The American University Press.

---. (1996) The Ottoman Legacy in the Balkans”. Imperial Legacy: The Ottoman Imprint on the Balkans and the Middle East. edited by L. C. Brown. New York: Columbia University Press.

---. (1997) Imaging the Balkans. New York: Oxford University Press.

---. Ed. (2004) Balkan Identities: Nation and Memory. New York: New York University Press.

---. (2006) Eanguage in the Construction of Ethnicity and Nationalism: The Bulgarian Case". Nationalities Affairs. 28, 2006. pp. 7-30.

---. (1990) Eanguage as Cultural Unifier in a Multilingual Setting: The Bulgarian Case During the Nineteenth Century". East European Politics and Societies. Vol. 4, No.3, Fall, 1990. 
Traikov, Nikola. Ed. (1957) Archive of G. S. Rakovski. Letters to Rakovski 1841-1860, II. Sofia: BAN. (Трайков, Никола. 1957. Архив на Георги Раковски. Писма до Раковски 1841-1860, II. София: БАН.)

---. Ed. (1966) Archive of G. S. Rakovski. Letters to Rakovski 1861, III. Sofia: BAN. (Трайков, Никола. 1966. Архив на Георги Раковски.Писма до Раковски 1861, III. София: БАН.)

Traikov, Veselin. Ed. (1969) Archive of G. S. Rakovski. Letters to Rakovski 1862-1867, IV. Sofia: BAN. (Трайков, Веселин. 1969. Архив на Георги Раковски. Писма до Раковски 1862-1867, IV. София: БАН.)

Trencsényi, Balázs and Kopecek, Michal. Ed. (2006) Discourses of Collective Identity in Central and Southeast Europe (1770-1945): National Romanticism The Formation of National Movements. Budapest: Central European University Press.

Tsaneva, Milena. (1989) In the Pages of Under the Yoke. Sofia: Bulgarian Writer. (Цанева, Милена. 1989 По страниците на Под Игото. София: Български писател.)

---. (1995). Ivan Vazov: Creative Portraits. Sofia: Bulgarian Writer. (Цанева, Милена. 1995. Иван Вазов: Творчески портрети. София: Просвета.)

---. (2005) Myth of the heroic HOME in the novel Under the Yoke". Bulgarian Language and Literature (electronic version). No. 1, 2005. (Цанева, Милена. „Митологизация на героичното начало в романа Под игото. Български език u литература. електронна версия, № 1, 2005.) http://liternet.bg/publish11/m_tonova/mitologizaciia.htm.

---. - On National Epic Under the Yoke: Genre and Compositional Characteristics and the Ideological and Emotional Pathos” (За националната епопея „Под Игото" жанрово-композиционни особености и идейно--емоционален патос). http://myschoolbel.info/Temil1_Vazov.html.

---. Author's Voice in Under the Yoke or on Narrative Strategies of Vazov". (Авторският глас в Под Игото или за повествователните стратегии на Вазов.) http://www.kaminata.net/avtorskiyat-glas-v-pod-igoto-t39029.html

Tsaneva, Milena \& Todorov, Iliya. (1988) Българската критика за Иван Вазов. София: Български писател. (Цанева, Милена \& Тодоров Илия. 1988. Bulgarian Criticism on Ivan Vazov. Sofia: Bulrarian Writer.)

Tsonev, В. (1919) History of Bulgarian Language Vol. I. Sofia. (Цонев, Б. 1919. История на българския език. Том първи. София.) 
---. (1934) History of Bulgarian Language. Vol. II. posthumous edition. Sofia. (Цонев, Б. 1934. История на българский език. т. II. посмъртно издание. София. 1934.)

Tuminez, Astrid S. (2000) Russian Nationalism since 1856: Ideology and the Making of Foreign Policy. Rowman \& Littlefield Publishers.

Tziovas, Dimitris. Ed. (2003). Greece and the Balkans: Identities, Perceptions and Cultural Encounters since the Enlightenment. Burlington: Ashgate.

Vazov, Ivan. (1912) Under the Yoke: A Romance of Bulgarian Liberty. London: William Heinemann.

---. (1956): Collected Works, Vol. XII, Sofia: Bulgarian writer.

---. (1960) Under the Yoke: A novel about the life of the Bulgarian people on the eve of the Liberation. Sofia: Foreign Languages Press.

---. (1982) Under the Yoke. Beijing: People‘s Literature Publishing House. (伐佐夫: 《轭下》, 北京: 人民文学出版社, 1982 年。)

---. (1986) Under the Yoke. Sofia: Bulgarian Writer. (Вазов, Иван. 1986. Под Игото. София: Български писател.)

Venedictov, G. (1979) -Eriteria of Renaissance Writers in Choosing the Dialectal Basis for the Bulgarian Literary language". Modern Language History Studies in the Nineteenth Century. Sofia. pp. 13-21. (Венедиктов, Г. „За критериите на възрожденските книжовници при избора на диалектна основа за българския книжовен език”. В: Изследвания из историята на новобългарския език през XIX в. София. стр. 13-21.

---. (1983) Bulgarian Language and Bulgarian Folk Speech. Modern Bulgarian Literary Language. Sofia. 1983. pp. 43-46. (Венедиктов, Г. 1983. „Българският книжовен език и българските народни говори”. В: Съвременният български книжовен език. София. стр. 43-46.)

Vinogradov, V. V. (1945). Russian Language (in Russian). Moscow.

Weeks, T. R. (1996). Nation and State in Late Imperial Russia: Nationalism and Russification on the Western Frontier, 1863-1914. DeKalb: North Illinois University Press.

Wei, C. X. George and Liu, Xiaoyuan. Ed. (2001) Chinese Nationalism in Perspective: Historical and Recent Cases. Westport: Greenwood Publishing Group. 
Wendt, Alexander. (1987) The Agent-structure Problem in International Relations Theory". International Organization. Vol. 41, No. 3, 1987. pp. 315-348.

---. (1992) Anarchy is What States Make of It: The Social Construction of Power Politics". International Organization. Vol. 46. No. 2, 1992. pp. 391-425.

---. (1999). Social Theory of International Politics. Cambridge University Press.

---. (2003) Social Construction of International Society. Cambridge Studies in International Relations. Cambridge University Press.

West, Lois A. Ed. (1997) Feminist Nationalism. New York: Routledge.

Wexler, Paul. (1974) Purism and Language. Indiana University Publications.

White, G. W. (2000) Nationalism and Territory: Constructing Group Identity in Southeastern Europe. Lanham: Rowman \& Littlefield Publishers, Inc.

Wilson, William A. (1973) Herder, Folklore, and Romantic Nationalism. Journal of Popular Culture 6 (Spring): 819-835.

Wright, Sue. (2004) Language Policy and Language Planning. New York: Palgrave Macmillan.

Yuval-Davis, N. (1997) Gender and Nation. London: Sage.

The Archives Tell: Russia and the Restoration of the Bulgarian State 1878-1885, Sofia University Press. 2008. (Архивите говорят: Русия и възстановяването на българската държавност /1878-1885 г., УИ Єв. Климент Охридски”, 2008.)

Group compilers. (1966). Overview: The Archives, Collections and Individual Collections Stored in Bulgarian Historical Archive Book 1-IX, Sofia: Science and Art. (Колективи сьставители. 1966. Обзор: На архивните фондове, колекции и единични постъпления, съхранявани в български исторически архив книга I-IX, София: Наука и изкуство.)

Scientific Centre for Bulgarian National Strategy. (1997) Bulgaria in the 21th Century - Bulgarian National Doctrine. Vol. I. Sofia. (Научния центьр за българска национална стратегия. 1997. България през двадесет и първи век - Българска национална доктрина. бр. І. София.)

\section{NEWSPAPER SOURCES}


Tsarigradski Week, 1848-1862, Istanbul. (Цариградски вестник, 1848-1862, Цариград.)

Liberty, 1869-1872. (Свобода, 1869-1872.)

Independence, 1873-1874. (Независимост, 1873-1874.)

Bulgarian, 1878. (Българин, 1878.)

Dabube Swan, 1860-1861. (Дунавски лебед, 1860-1861.)

Slavonic Brotherhood, 1878. (Славянско братство, 1878.)

Flag, 1874. (Знаме, 1874.) 


\section{CURRICULUM VITAE}

\section{EDUCATION}

- $2006-2014$

Ph. D., Humanities, University of Louisville, Kentucky, USA, (expected Apri1 2014)

- 1999 - 2002

M. A., Bulgarian Language and Literature, Beijing Foreign Studies University, China

- $1993-1997$

B. A., Bulgarian Language and Literature, Beijing Foreign Studies University, China

\section{WORK EXPERIENCE}

- $\quad 1997-2003$

Assistant of Bulgarian Language and Literature, Beijing Foreign Studies University

- $2003-2009$

Lecturer of Bulgarian Language and Literature, Beijing Foreign Studies University

- 2009 - present

Associate Professor of Bulgarian Language and Literature, Beijing Foreign Studies University

\section{PUBLICATIONS}

BOOKS 
- Bulgarian Listening Course, Beijing: Foreign Language Teaching and Research Press, 2004.

\section{ARTICLES}

- "Shi Zhecun and Eastern European Literature" , Chinese Journal of European Language and Cultures, Vol. VII (2013): 251-260.

- "Howl from the Black Sea - Reception of Bulgarian Literature in China” , Chinese Culture in Eastern Europe, (2013): 50-64.

- "Passing on the Heritage - Translation of Eastern European Literature by Lu Xun and Sun Yong” , Journal of Sino-Western Cultural Studies, Vol.2 (2006): 51-60

- “The Moments of Translation of Bulgarian Literature in China” , Language and Literature, Vol. 3-4 (2009) : 28-36.

- “Balkanization: Global Political Epidemic” , World Affairs, Vol. 12 (2009) : 46-47.

- "Grand Absences in Bulgarian Postmodern Literature", Chinese Journal of European Language and Cultures, Vol. III (2007) : 165-173.

- "War in Lyrics” , Chinese Journal of European Language and Cultures, Vol. II (2006) : 297-306.

\section{ONGOING RESEARCH PROJECTS}

- "Humanistic Discovery in the Balkans” , Optional Project of Beijing Foreign Studies University.

- "Analysis on Minority Issues in Central-Eastern European Countries”, Optional Project of Beijing Foreign Studies University. 